UNIVERSIDADE DE SÃO PAULO

ESCOLA DE COMUNICAÇÕES E ARTES

DEPARTAMENTO DE MÚSICA

JULIANO ABRAMOVAY

\title{
Quarteto de cordas em sol menor de Claude Debussy: reiterações e aspectos formais
}

Dissertação apresentada ao Programa de Pós-graduação em Música, Área de Concentração Processos de Criação Musical, Linha de Pesquisa em Técnicas Composicionais e Questões Interpretativas, da Escola de Comunicações e Artes da Universidade de São Paulo, como exigência parcial para obtenção do título de Mestre em Música, sob orientação do Prof. Dr. Paulo de Tarso Salles

São Paulo 
Autorizo a reprodução e divulgação total ou parcial deste trabalho, por qualquer meio convencional ou eletrônico, para fins de estudo e pesquisa, desde que citada a fonte.

Catalogação na Publicação Serviço de Biblioteca e Documentação

Escola de Comunicações e Artes da Universidade de São Paulo Dados fornecidos pelo(a) autor(a)

Abramovay, Juliano

Quarteto de cordas em sol menor de Claude Debussy:

reiterações e aspectos formais / Juliano Abramovay. -- São

Paulo: J. Abramovay, 2014.

115 p.: il.

Dissertação (Mestrado) - Programa de Pós-Graduação em Música - Escola de Comunicações e Artes / Universidade de São Paulo.

Orientador: Paulo de Tarso Salles

Bibliografia

1. Claude Debussy 2. Quarteto de cordas em sol menor opus 10 3. Análise musical 4. Forma cíclica 5. Reiteração I. Salles, Paulo de Tarso II. Título. 
Nome: ABRAMOVAY, Juliano

Título: Quarteto de cordas em sol menor de Claude Debussy: reiterações e aspectos formais

Dissertação apresentada ao Programa de Pós-graduação em Música, Área de Concentração Processos de Criação Musical, Linha de Pesquisa em Técnicas Composicionais e Questões Interpretativas, da Escola de Comunicações e Artes da Universidade de São Paulo, como exigência parcial para obtenção do título de Mestre em Música, sob orientação do Prof. Dr. Paulo de Tarso Salles

São Paulo, de de 2014

Banca Examinadora

Prof. Dr. Instituição:

Julgamento: Assinatura:

Prof. Dr. Instituição:

Julgamento: Assinatura:

Prof. Dr. Instituição:

Julgamento: Assinatura: 


\section{Agradecimentos}

Ao Paulo, pela paciência e comprometimento com o qual me orientou ao longo desta pesquisa.

Aos meus pais e a minha família, pelo apoio incondicional.

A Maria Claudia, que acompanhou esta jornada desde o primeiro dia, por sua alegria.

A Francisco de Oliveira, pelos papos mais que esclarecedores.

A Denise, por todas as ajudas possíveis.

A Gabriela Maloucaze, pela seriedade na revisão.

Aos professores Maurício De Bonis e Rodolfo Coelho de Souza, pelas indicações fundamentais na banca de qualificação.

À Fundação de Amparo à Pesquisa do Estado de São Paulo (Fapesp), pela concessão da bolsa de mestrado que tornou possível a dedicação à pesquisa. 
RESUMO: O Quarteto de cordas em sol menor de Claude Debussy é uma obra marcada por importantes dicotomias. Composta em 1893, ela se encontra permeada de elementos harmônicos e formais ligados à tradição tonal e ao final do século XIX, particularmente ao compositor César Franck. Ao mesmo tempo, a peça utiliza procedimentos que são observados apenas em obras maduras do compositor, nas quais o tonalismo se encontra pouco presente, e análises que dependam exclusivamente de elementos tonais mostramse pouco eficientes para o Quarteto. Essa relação entre tradição e inovação é investigada nesta pesquisa, que traz como enfoque duas características diretamente relacionadas: a maneira como Debussy utiliza elementos repetidos nesta peça, assunto pesquisado por Sylveline Bourion, e aspectos relativos à forma cinética, elemento descrito por Richard Parks. Uma comparação entre o primeiro movimento do Quarteto e o primeiro movimento da Sonata para flauta, viola e harpa, peça do final da carreira de Debussy, é oportuna para que sejam observados elementos formais semelhantes aplicados em contextos diferentes.

PALAVRAS-CHAVE: Claude Debussy, Quarteto de cordas em sol menor opus 10, Análise musical, Forma cíclica, Reiteração. 
ABSTRACT: Claude Debussy's String quartet in G minor is a work characterized by important dichotomies. Written in 1893, the piece is permeated by harmonic and formal elements attached to the tonal tradition and to the end of the $19^{\text {th }}$ century, and specially to the composer César Franck. At the same time, the Quartet uses procedures observed only in Debussy's mature works, in which the presence of tonalism is weak, and analyses that rely exclusively on tonal elements are proven to have little efficiency regarding this piece. The relation between tradition and innovation is examined in this research, which focuses on two related characteristics: the way in which Debussy uses repeated elements in this piece, a matter also examined by Sylveline Bourion, and aspects related to the kinetic form described by Richard Parks. A comparison between the Quartet's first movement and the first movement from the Sonata for flute, viola and harp, composed at the end of Debussy's career, is useful for observing similar formal elements applied in different contexts.

KEYWORDS: Claude Debussy, String quartet in g minor opus 10, Musical Analysis, Cyclic form, Reiteration. 


\section{LISTA DE FIGURAS}

Figura 1: Representação da análise de Lockspeiser sobre o primeiro movimento do Quarteto de cordas em sol menor de Debussy..... .p.18

Figura 2: Lista de composições de Debussy e Franck (WHEELDON, 2005, p.646). ..p. 21

Figura 3: Gráfico prolongacional do primeiro movimento do Quarteto de Debussy (PARKS, 1989, p.13). p.27

Figura 4: Exemplos da utilização de diferentes espécies de conjuntos de classes de alturas no Quarteto (PARKS, 1989, p.105). .p.31

Figura 5: Gráfico schenkeriano representando o primeiro movimento do Quarteto de Debussy (YIH, 2000, p.207). .p.34

Figura 6: Dois processos transformacionais identificados por Yih. p.36

Figura 7: Análise de Yih dos motivos relevantes do Quarteto (YIH, 2000, p.2011) .p.37

Figura 8: Uso da construção cíclica nos Quartetos de cordas de César Franck e Claude Debussy (WHEELDON, 2005, p.648). .p.47

Figura 9: Aspectos da forma morfológica no Quarteto (PARKS, 1989, p.219).........p.51

Figura 10: Cc.17-23 do primeiro movimento do Quarteto (BOURION, 2011, p.281) ..p.56

Figura 11: Representação proporcional do tamanho das unidades reiteradas entre os cc. $13-25$ .p.57

Figura 12: Cc.23-25 do primeiro movimento. p.58

Figura 13: "Técnica do martelo e da bigorna” (BOURION, 2011, p.242-243)...........p.60

Figura 14: Cc.26-39 do primeiro movimento (BOURION, 2011, p.253)...................p.61

Figura 15: Cc.1-12 do primeiro movimento. .p.63 
Figura 16: Inversão no movimento das vozes extremas nos cc.1-2 e 179182 .p.64

Figura 17: padrão de reiterações presente entre os cc.39-60......................................p.65

Figura 18: Materiais temáticos dos primeiros sessenta compassos do primeiro

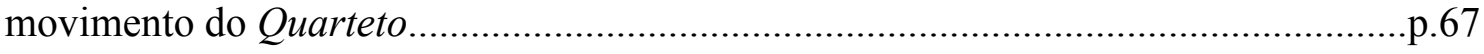

Figura 19: Representação da alternância entre duas texturas.....................................p.69

Figura 20: Material melódico do desenvolvimento e sua "raiz"................................p.71

Figura 21: Melodias do desenvolvimento, cc.88-112 ...........................................p. 72

Figura 22: Redução das vozes de acompanhamento entre os cc.88-112 (as notas brancas em losango representam a nota em que se inicia a melodia)....................................p.73

Figura 23: Comparação entre o uso de reiterações nos cc.13-25 e nos cc.103-117.....p.73

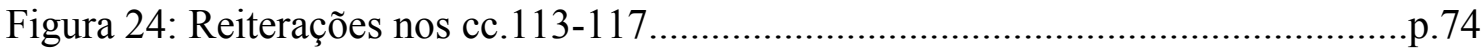

Figura 25: Vozes do violino I e violoncelo dos cc.113-114...................................p.75

Figura 26: Material harmônico dos cc.113-116......................................................p.75

Figura 27: Cc.113-116 sob diferentes planos formais, com ênfase na permanência das

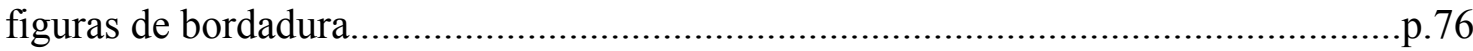

Figura 28: Cc.23-25 do primeiro movimento........................................................... 76

Figura 29: Alternância entre conjuntos de classes de alturas dos cc.122-123 e 128129. .p.77

Figura 30: Cc.136-137 com sua reiterações representadas entre colchetes e redução harmônica do trecho p.78

Figura 31: cc.120-131 com suas respectivas reiterações.........................................p.79

Figura 32: Elementos melódicos da terceira seção formal.......................................p. 80

Figura 33: Análise paradigmática textural do Quarteto.............................................p.82 
Figura 34: Ordem de aparição dos elementos na exposição e na recapitulação do primeiro movimento da Sonata para flauta, viola $e$ harpa .p. 87

Figura 35: apresentações temáticas no Quarteto e na Sonata para flauta, viola e harpa. p.87

Figura 36: Dois importantes gestos do primeiro movimento da Sonata para flauta, viola e harpa. p. 88

Figura 37: Exemplos de variações dois dos principais gestos do primeiro movimento da Sonata para flauta, viola e harpa .p.89

Figura 38: Ordem de apresentação dos materiais motívicos em Jeux; as letras A sublinhadas significam reapresentações literais, as não sublinhadas significam que apenas trechos são reapresentados (EIMERT, 1959, p.7) .p.89

Figura 39: Redução harmônica da Sonata para flauta, viola e harpa (ALLEN, 1983, p.40) .p.90

Figura 40: Estruturas harmônicas em diferentes planos formais p.91 


\section{SUMÁRIO}

INTRODUÇÃO. .p.12

CAPÍTULO 1: O Quarteto de cordas em sol menor de Debussy ao longo dos séculos XX e XXI

A compreensão formal da música de Debussy na primeira metade do século XX..............15

Uma nova aproximação à música de Debussy.................................................................p.20

Herbert Eimert, Debussy's “Jeux”: novas propostas de abordagem analítica......................2.22

A utilização de ferramentas analíticas da segunda metade do século XX aplicadas ao

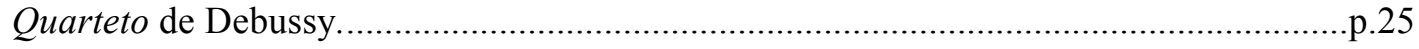

Debussy e a condução melódica e harmônica a partir da ideia de prolongação...................p.25

O Quarteto sob uma perspectiva da teoria dos conjuntos....................................................30 Annie Yih, Analysing Debussy: Tonality, Motivic Sets and the Referential Pitch-Class Specific Collection - ênfase na elaboração motívica.............................................................32

CAPÍTULO 2: Forma cíclica, forma cinética e o uso de reiterações

A forma cíclica e o Quarteto de cordas em sol menor de Debussy....................................39

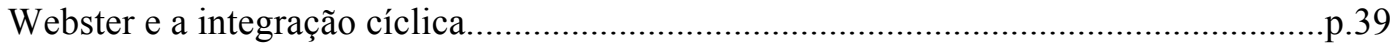

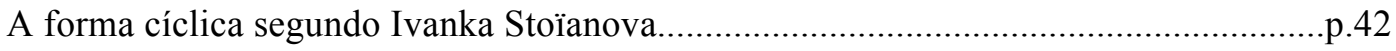

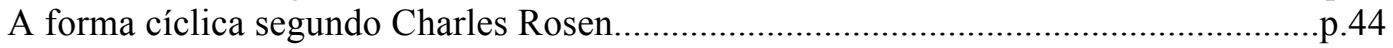

Marianne Wheeldon e a forma cíclica em Debussy e César Franck..................................45

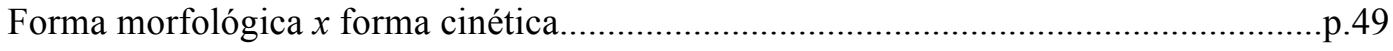

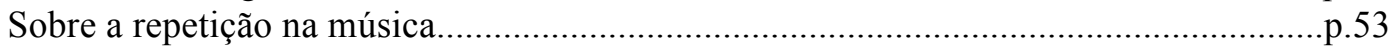

Sylveline Bourion e a repetição em Debussy.......................................................................5.

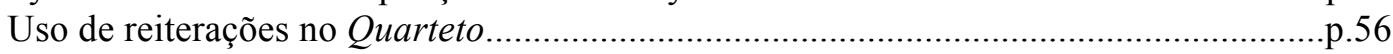

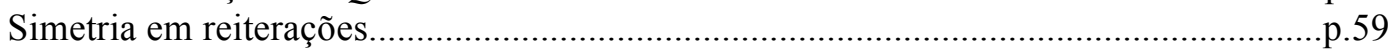

\section{CAPÍTULO 3: Propostas analíticas para o Quarteto}

Exposições temáticas e a forma cinética.............................................................................6

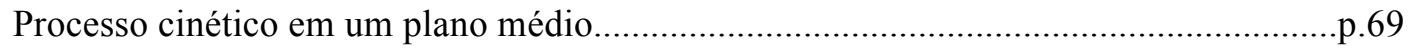

Aspectos relativos à forma cinética na segunda seção formal do Quarteto.......................p.70

Investigando aspectos relativos à reiteração......................................................................74

Bordaduras harmônicas em um plano elevado...............................................................p.77

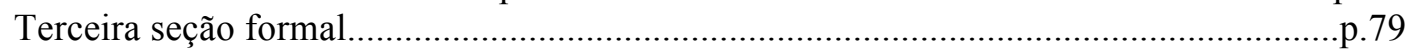

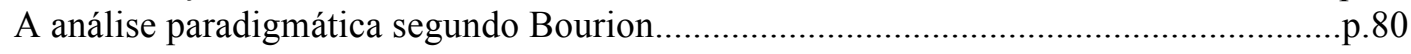

A forma sonata dentro do Quarteto......................................................................... 81 
Uma breve comparação entre os primeiros movimentos do Quarteto em sol menor e a

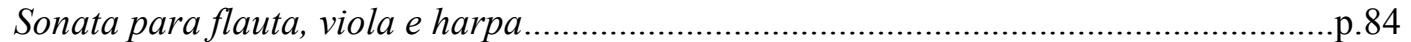

Influências na forma cíclica da sonata para flauta, viola e harpa...................................p.85

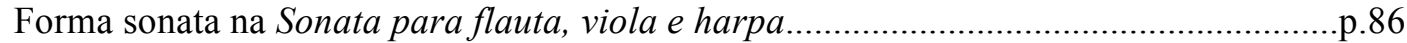

Apresentações temáticas: comparação entre o Quarteto e a Sonata..................................p.87

Simetria em um plano formal em larga escala na Sonata para flauta, viola e harpa.......p.90

CONCLUSÃO

.p. 92

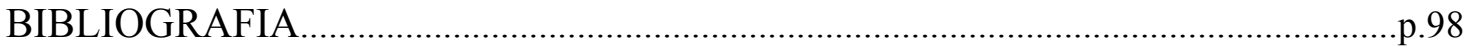

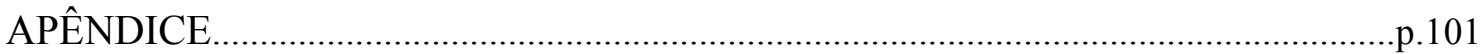




\section{Introdução}

Ao longo das últimas décadas, diferentes aproximações analíticas foram realizadas para discutir a música de Debussy. Métodos derivados da teoria schenkeriana estendida utilizando gráficos prolongacionais, elementos advindos da teoria dos conjuntos aplicada à música e conceitos da Semiótica são algumas das principais ferramentas analíticas utilizadas na música do compositor francês. Tal diversidade pode ser explicada por uma particularidade que faz com que Debussy se destaque entre os grandes renovadores da música: poucos compositores foram capazes de trazer tantas contribuições para a música do século XX e, ao mesmo tempo, demonstrar uma ligação tão forte à música do passado. Boa parte de sua música é permeada por elementos advindos da tradição tonal e, mesmo que muitas vezes não seja possível realizar uma análise harmônica que dê conta de explicar totalmente a peça, importantes elementos formais provenientes do tonalismo encontram-se presentes em diferentes níveis. Tal fato problematiza a questão da análise de forma bastante rica, pois ao lidar com estas questões, o analista precisa compreender de que maneira cada um destes aspectos contribui para o seu entendimento da peça de modo mais amplo.

O Quarteto de cordas em sol menor, opus 10, de Debussy é uma peça bastante particular neste sentido. Composta entre 1892-1893 e estreada em dezembro desse ano, é seu único quarteto de cordas e uma das poucas composições para música de câmara do autor e a única no gênero "quarteto de cordas". Antes dele, Debussy havia composto seu Trio em sol maior (1880) e passa, então, quase vinte anos afastado da composição camerística (compõe apenas as Canções de Bilitis em 1900-1901).

Na década de 1910, Debussy retoma a música de câmara com Petite pièce (1910), Rapsódia para clarinete (1910), Syrinx (1913) e as três sonatas de câmara; Sonata para violoncelo e piano (1915), Sonata para flauta, viola e harpa (1915) e Sonata para violino e piano (1916-1917). É interessante notar que tal retorno à música de câmara ao final de sua carreira também é acompanhado por uma volta de elementos ligados ao tonalismo, especialmente em suas três sonatas. Esse fato indica que pode haver em Debussy uma relação entre a música de câmara e elementos da tradição tonal: segundo Pierre Boulez (1995, p.300), o quarteto de cordas é uma das formas (ou "gêneros") musicais menos propensas a aceitar elementos de "modernidade". 
No primeiro movimento do Quarteto de cordas em sol menor, é possível identificar importantes elementos advindos da tradição tonal. Em alguns momentos da peça, tríades e tétrades formam acordes capazes de estabelecer relações tonais, e a estrutural formal da obra é construída levando em conta princípios estabelecidos entre os séculos XVIII e XIX - esta é uma das possíveis razões para que alguns autores avaliem a peça como detentora de uma linguagem "conservadora" (como em PARKS, 1989, p. 217). Porém, elementos advindos do tonalismo sozinhos não são capazes de fornecer uma análise satisfatória da peça. Importantes ferramentas composicionais observadas na peça não pertencem a padrões tonais, e para avaliar a peça apenas segundo estes critérios é preciso deixar de lado trechos significativos da obra.

Nesse sentido, o Quarteto de cordas em sol menor representa um paradigma na música de Debussy, que surge não apenas por suas inovações harmônicas e virtuosísticas (trata-se de uma peça de grande dificuldade, com importantes inovações técnicas, e nisso ela precede os quartetos de Bártok), mas também por conta de um sutil jogo entre a apropriação de elementos da tradição musical - sejam eles advindos de cânones da música ocidental europeia ou da tradição romântica francesa do fím do século XIX - e a inovação, a ruptura com estes elementos. Com isso, a peça torna-se um interessante objeto de estudo para compreender de que maneira a tradição tonal é empregada e qual é, de fato, sua importância nesse período composicional de Debussy.

Este trabalho é dividido em três capítulos. O primeiro capítulo investiga o que já foi escrito sobre o primeiro movimento do Quarteto de Debussy entre os séculos XX e XXI. Observaremos que diferentes metodologias analíticas foram aplicadas à obra, e a discussão sobre o papel do tonalismo no Quarteto - uma problematização frequente em obras de Debussy - também é trazida a tona. Além de trazer contribuições analíticas fundamentais para a peça, o capítulo também apresenta uma importante mudança na compreensão da música de Debussy ao longo dos séculos XX e XXI, quando o destaque dado a elementos advindos da tradição tonal é constantemente alterado.

O segundo capítulo esclarece aspectos relativos ao conceito de forma cíclica, que permeia a peça, e apresenta importantes estratégias analíticas que serão utilizadas dentro do Quarteto, assim como a diferença entre forma morfológica e forma cíclica e a maneira como Debussy faz uso de reiterações nesta peça, trazendo algumas contribuições analíticas com relação ao uso de reiterações.

O terceiro capítulo apresenta uma análise de trechos da peça, colocando em prática os conceitos observados no capítulo anterior e buscando também ampliá-los. A 
comparação entre os primeiros movimentos do Quarteto de cordas em sol menor e da Sonata para flauta, viola e harpa apresenta semelhanças e diferenças entre duas peças com características similares, porém situadas em períodos opostos da carreira de Debussy, demonstrando de que maneira importantes elementos formais são ressignificados na obra do final de sua carreira. O apêndice é formado por uma tabela com os principais elementos formais do primeiro movimento do Quarteto e sua partitura com todas a reiterações da peça indicadas. A visualização da peça inteira, com seus elementos reiterados em destaque, é importante para mostrar a grande quantidade de reiterações presentes, nem sempre passíveis de serem indicadas em exemplos no texto da pesquisa.

O objetivo deste trabalho não é apresentar uma análise que explique todos os elementos presentes no Quarteto de Debussy com o objetivo de encontrar uma unidade presente na música. Buscou-se uma melhor compreensão de conceitos analíticos que, aplicados a esta peça, são capazes de revelar questões que muitas vezes passam despercebidas em análises musicais. Desta maneira, pretende-se apresentar uma aplicação de novas ferramentas analíticas a esta peça, possivelmente estimulando o uso destas ferramentas em outras composições musicais de Debussy ou de diferentes compositores. 


\section{O Quarteto de cordas em sol menor de Debussy ao longo dos séculos XX e XXI}

Uma série de textos relacionados ao Quarteto de cordas em sol menor de Claude Debussy foi pesquisada para este trabalho. Alguns se tornaram base para $o$ desenvolvimento desta pesquisa; outros, ainda que tenham contribuído em diferentes níveis, acabaram desempenhando aqui um papel mais periférico. Este capítulo tem como objetivo apresentar textos que mencionam o Quarteto de Debussy ou que contribuem de alguma forma para uma melhor compreensão analítica da peça.

Por meio de trechos dos livros Debussy (LOCKSPEISER, 1936), Apontamentos de aprendiz (BOULEZ, 1994), The Music of Claude Debussy (PARKS, 1989), e dos artigos Debussy's Jeux (EIMERT, 1959) e Analysing Debussy (YIH, 2000), pretende-se chegar a dois resultados: apresentar contribuições analíticas que resultem numa melhor compreensão do Quarteto e, mais importante, demonstrar que existiu ao longo dos séculos XX e XXI uma importante mudança na maneira de compreender analítica e estruturalmente a música de Claude Debussy.

\section{A compreensão formal da música de Debussy na primeira metade do século $\mathrm{XX}$}

Um dos mais importantes especialistas em Debussy do século XX, Edward Lockspeiser, possui uma extensa bibliografia sobre o compositor francês. É o autor de Debussy: his Life and Mind, publicada em dois volumes entre 1962 e 1965. Em outro de seus livros a respeito do compositor, Debussy, publicado pela primeira vez em 1936, ele divide a obra do compositor por gêneros instrumentais, dedicando as páginas iniciais da seção de música de câmara ao Quarteto de cordas em sol menor (LOCKSPEISER, 1936, p.151-158). O autor inicia esse trecho com uma pergunta provocadora: "Como Debussy superou sua inabilidade natural para usar a forma sonata, que é, afinal, necessária em um quarteto em larga escala?”.

A frase traz duas afirmações bastante arrojadas; existiria de fato uma inabilidade natural por parte de Debussy na utilização da forma sonata? E seria este modelo formal realmente essencial para a composição de um quarteto de cordas? 
O autor não se aprofunda sobre nenhuma das duas afirmações, o que dificulta tal problematização. Porém, é fato que existem peças de Debussy anteriores ao Quarteto de cordas em que é possível observar a presença sólida da forma sonata e que tal modelo formal é encontrado com irregularidades no Quarteto (irregularidades estas que serão observadas no capítulo 2). Em obras posteriores de Debussy, não se observa mais a utilização deste padrão formal: trata-se de uma característica de peças do início de sua carreira. Esse fato permite que se indague se o progressivo abandono não se daria pela suposta falta de habilidade do compositor no manejo da forma sonata. Porém esta mudança específica (o abandono da forma sonata) ocorre dentro de um contexto mais amplo de mudanças de técnicas composicionais, em que observamos não apenas uma diminuição no uso de modelos formais provenientes do tonalismo como também importantes mudanças no tamanho de unidades repetidas ${ }^{1}$ (na forma sonata é implícita a repetição de uma grande seção formal). Assim, em vez de uma falta de habilidade ainda que não seja possível afirmar de forma categórica que não haja uma falta de habilidade neste período do compositor - parece mais lógico apontar para uma falta de interesse do compositor em utilizar rigorosamente esse modelo formal. Além disso, observaremos posteriormente que a forma sonata retorna ao final da carreira de Debussy de maneira inovadora, problematizando de forma interessante a relação entre tradição e ruptura no aspecto formal.

É importante ressaltar que a problematização da questão formal na música do final do século XIX e início do século XX não se encontra restrita à música de Debussy: trata-se de um tema extensamente debatido em toda a primeira metade do século XX, em especial após a solidificação da dicotomia entre a música de Arnold Schoenberg e a música de Igor Stravinsky². Neste sentido, o termo "quarteto de cordas" adquire uma interessante particularidade, pois não se refere apenas a uma peça composta para dois violinos, viola e violoncelo. Ao conceber um quarteto de cordas, o compositor desse período também carrega uma bagagem formal que se encontra implícita no uso do termo, e um escape desses padrões formais preconcebidos muitas vezes era visto com estranhamento. Boulez (1995, p.299) sintetiza este pensamento referindo-se à recepção do Quarteto de Debussy em sua estreia: "Surpreenderam-se por encontrar uma obra que

1 A mudança na maneira como Debussy faz uso de elementos repetidos é alvo de análise no capítulo 2 desta dissertação.

2 Em A filosofia da nova música, Adorno problematiza a questão da forma na música da primeira metade do século XX de maneira bastante profunda, dando ênfase especial a aspectos formais dentro do dodecafonismo (ADORNO, [1958] 1962, p.104-107). 
não era um verdadeiro quarteto, isto é, que não obedecia aos esquemas tradicionais extraídos das obras-primas vienenses".

Outros compositores também tiveram que lidar com esta questão ao escreverem para a formação. Stravinsky dá o título de Três peças para quarteto de cordas para uma composição sua de 1914, possivelmente com o objetivo de evitar uma associação a modelos formais. O Quarteto $n^{o} 1$ de Heitor Villa-Lobos, composto em 1915, é formado por seis curtos movimentos: tal liberdade formal, segundo Salles, causou decepção ao Quarteto Iacovino ao receber a obra do compositor como sugestão de concerto em 1943 (SALLES, 2012, p.83). A ênfase em aspectos formais de livros como Fundamentos da composição musical (SCHOENBERG, 1991), com um capítulo inteiro dedicado às "grandes formas", também é representativa para compreender a importância dada a estes aspectos na primeira metade do século XX.

Portanto, é compreensível o fato de que Lockspeiser julgue a forma sonata como um elemento imprescindível para um quarteto de cordas. Porém, nos últimos sessenta anos de desenvolvimento da tradição musical, tanto em discussões teóricas quanto em composições para quarteto de cordas, a estrutura formal da composição musical deixou de depender de noções tradicionais como a forma sonata. Um exemplo de ferramenta composicional que surge (entre outras razões) para preencher o vazio deixado pelo abandono de tais modelos formais é o serialismo integral, desenvolvido em meados da década de 1950. Hoje, é possível considerar o conceito de forma sonata como pertencente a um determinado período histórico e geográfico, e não como um elemento imprescindível para a composição de um quarteto de cordas.

Para solucionar as duas questões colocadas acima, Lockspeiser (1936, p.151) afirma que "[Debussy] depende, ao longo dos quatro movimentos e em um movimento inteiramente, da sutil transformação de um único motivo”. De fato, tais transformações motívicas são consideradas como um dos pilares do Quarteto por todos os autores observados nesta pesquisa. Porém, é interessante notar a ausência do termo "forma cíclica", também onipresente em outros textos sobre o Quarteto de Debussy e com frequência associado a estas transformações de um motivo ao longo de uma peça com mais de um movimento; é possível que tal termo não se encontrasse em voga no período. Na sequência, o autor realiza uma breve análise das duas primeiras seções formais do primeiro movimento. 
$\mathrm{Na}$ exposição, existem dois episódios (que não são contratemas) que atravessam com pouco efeito a estrutura geral da peça. Na realidade, eles jamais são escutados novamente. $\mathrm{O}$ motivo principal aparece com mudanças prismáticas de harmonia, mas melodicamente é pouco desenvolvido. O segundo sujeito aparece apenas no fim da exposição. A seção de desenvolvimento - pois Debussy busca aqui uma espécie de forma ternária - consiste em uma série de variações pequenas colocadas juntas em um mosaico. Elas são principalmente sobre o segundo sujeito. (LOCKSPEISER, 1936, p.152 ${ }^{3}$ )

O gráfico a seguir apresenta a visão de Lockspeiser sobre o trecho, com base nas afirmações anteriores.

\begin{tabular}{|c|c|c|c|c|c|}
\hline \multicolumn{5}{|c|}{ exposição } & \multirow[t]{2}{*}{ desenvolvimento } \\
\hline c.1 & c. 12 & c. 26 & c.39 & $c_{i} 63$ & \\
\hline $\begin{array}{l} \\
\text { motivo } \\
\text { principal }\end{array}$ & $1^{\circ}$ episódio & $\begin{array}{l}\text { motivo } \\
\text { principal } \\
\text { (mudança de } \\
\text { harmonia) }\end{array}$ & $2^{\circ}$ episódio & $2^{\circ}$ sujeito & \\
\hline
\end{tabular}

Ao referir-se à reexposição, terceira seção formal da forma sonata, Lockspeiser não realiza uma análise semelhante à realizada na exposição:

Chega-se ao final da [segunda] seção não, como em Beethoven, para ver uma significância mais profunda no sujeito motívico, mas para ser fascinado por um pouco mais de tempo por outras variações, desenhos e mutações harmônicas. O movimento termina baseado na primeira metade do motivo principal. (LOCKSPEISER, 1936, p.153)

De fato, uma análise que buscasse uma reapresentação da forma sonata na última seção formal da peça seria feita com muita dificuldade, pois após a retomada do tema inicial nos cc.138-141, não encontramos qualquer elemento pertencente à primeira seção formal que seja retomado. Isso reforça a ideia de que existe um enfraquecimento no papel da forma sonata dentro desta peça.

\footnotetext{
3 Todas as traduções em citações diretas e indiretas são de nossa autoria, salvo quando indicado o contrário.
} 
A conclusão da breve análise de Lockspeiser merece destaque, pois traz luz à maneira como a música de Debussy era compreendida, de modo geral, ao longo da primeira metade do século XX:

Debussy escreveu este quarteto com trinta anos. Como é diferente do Quarteto de cordas em Fá maior, op. 18 n.1 de Beethoven! Aquela unidade filosófica, aquela dignidade, aquele drama que Beethoven concebia não significava nada a Debussy. Em sua essência, suas qualidades são efêmeras. Assim como a estrutura espaçosa de Beethoven depende do amadurecimento de ideias, a forma semelhante a um mosaico de Debussy é feita para convir a uma série de sensações. Lembro-me do que Franck disse sobre Debussy: "é música em ponta de agulhas". Pode-se dizer que o Quarteto é música dos nervos. É uma música que nos delicia como nenhuma outra - enquanto durar. (LOCKSPEISER, 1936, p.158)

A comparação entre Debussy e Beethoven feita por Lockspeiser condiz com a visão da época sobre estes dois compositores, colocando-os em polos opostos do processo composicional: Beethoven possui "unidade filosófica" e depende do "amadurecimento de ideias", enquanto Debussy utiliza uma "forma semelhante a um mosaico", "feita para convir a uma série de sensações", uma "música em ponta de agulhas".

Implícita na citação está a associação (também frequente neste período) entre o compositor francês e o movimento impressionista, ou pontilhista, presente nas artes plásticas entre o fim do século XIX e o início do século XX. Em certo sentido, trata-se de uma maneira de categorizar Debussy como um compositor intuitivo, um gênio cuja metodologia composicional não é compreendida e, consequentemente não pode ser analisada. Considera-se este um ponto de vista pouco enriquecedor para a discussão analítica, pois limita a capacidade de atuação de um pesquisador. Além disso, foram desenvolvidas ao longo dos séculos XX e XXI ferramentas analíticas que elucidam importantes questões sobre o processo composicional de Debussy, permitindo que peças como o Quarteto de cordas em sol menor sejam abordadas com um olhar muito mais claro e menos preso a questões tradicionalistas que, mesmo que por vezes contribuam para uma visão analítica mais esclarecida, nem sempre são fundamentais para compreender a obra de Debussy e de outros compositores do período.

A análise de Lockspeiser é vista aqui como representativa de um período histórico cronologicamente próximo a Debussy, no qual se tentava enquadrar a sua música em modelos formais do passado, comparando suas estruturas a arquétipos do tonalismo. Ainda que reconhecessem seu valor, os teóricos da época, na maior parte das 
vezes, não eram bem-sucedidos na tarefa de identificar quais elementos de fato eram estruturais para o compositor. Tal fato pode dar-se pela necessidade de que haja um tempo para que ideias musicais sejam amadurecidas, que relações harmônicas e formais sejam deduzidas e uma síntese teórica possa ser elaborada.

\section{Uma nova aproximação à música de Debussy}

Em uma curta biografia de Claude Debussy, escrita por Boulez (1995 [1958], p.299-310), encontram-se comentários sobre o Quarteto de cordas em sol menor que dialogam com os de Lockspeiser.

É difícil compreender, hoje em dia, as reticências com que foi recebida essa primeira audição [do Quarteto de Debussy]: como música de câmara, o quarteto de cordas passava por ser a quintessência da arte musical, mas o espírito das pessoas mais capazes de apreciar essa obra estava repleto de preconceitos ligados à lembrança da escola vienense (Haydn, Mozart e mais especialmente Beethoven, cuja descoberta na França era relativamente recente). Surpreenderam-se por encontrar uma obra que não era um verdadeiro quarteto, isto é, que não obedecia aos esquemas tradicionais extraídos das obras-primas vienenses. Os modelos na época eram César Franck e Vincent d'Indy; mesmo o Andantino do quarteto não deixa de ter umas reminiscências de César Franck. Apesar da construção "cíclica" adotada, o quarteto de Debussy, por sua liberdade formal, pela harmonia nova em sua essência, pela escrita instrumental, que nas melhores páginas nada devia aos predecessores conhecidos, desnorteou o amador esclarecido: o próprio Ernest Chasson, então amigo íntimo de Debussy, não podia aceitar integralmente uma obra que, em sua opinião, ia contra os cânones estéticos considerados como intangíveis [...]. (BOULEZ, 1995, p.299-300, tradução: Moutinho, Pagano, Bazarian)

Aqui, Boulez aprofunda-se sobre o que Lockspeiser chamou "sutis transformações de um único motivo": trata-se de uma construção cíclica que possui como modelo os compositores César Franck e Vincent d'Indy. A influência de Franck neste período composicional de Debussy não se restringia a modelos formais. A tabela a seguir apresenta uma comparação entre obras dos dois compositores, sugerindo que Debussy com frequência utilizava gêneros e instrumentações próximos ou idênticos às de obras de Franck compostas alguns anos antes ${ }^{4}$.

4 A discussão sobre a influência de Franck em Debussy é retomada no item "Marianne Wheeldon e a forma cíclica em Debussy e César Franck", no qual a questão da forma cíclica é aprofundada. 


\begin{tabular}{ll}
\hline Franck & Debussy \\
\hline Psyché (1886) & Printemps (1887) \\
Symphonic poem with chorus & Symphonic suite with chorus \\
Variations symphoniques (1885) & Fantaisie (1889) \\
Concerto for piano and orchestra & Concerto for piano and orchestra \\
String Quartet in D major (1889) & String Quartet in G minor, Op. 10 (1893) \\
Violin Sonata (1886) & Projected Violin Sonata (1894) \\
\hline
\end{tabular}

Figura 2: Lista de composições de Debussy e Franck (Wheeldon, 2005, p. 646)

Porém, em vez de tentar aplicar noções formais tradicionais, como faz Lockspeiser, Boulez reconhece no Quarteto uma liberdade formal que, associada à nova harmonia e a sua escrita instrumental, seria uma das razões para o pouco impacto que a obra teve em sua estreia.

Boulez também confronta Debussy, não com Beethoven, mas com seus sucessores; no entanto, aqui o autor do Quarteto não é visto como um músico cuja forma "é feita para convir uma série de sensações":

[...] Esse quarteto marca uma renovação inegável no espírito da música de câmara, liberta-a da estrutura rígida, da retórica imobilizada e da estética rigorista em que os sucessores de Beethoven mantinham-na prisioneira; essa obra introduz a "modernidade" numa das formas da literatura musical menos propensas a aceitá-la, quando mais não fosse pelo número restrito e as exigências de uma casta: a dos “amadores esclarecidos”. (Boulez, 1995, p.300, tradução: Moutinho, Pagano, Bazarian)

Fica clara, desta forma, a importante mudança de compreensão na década de 1930 e na década de 1960 sobre o que seria a obra de Debussy. Lockspeiser reconhece que o Quarteto traz importantes mudanças para a música de câmara, porém ainda busca realizar uma análise tradicional da peça, deixando de perceber, possivelmente pela proximidade cronológica do autor com o compositor, que existe uma ruptura importante, essa libertação das estruturas rígidas em que os sucessores de Beethoven mantinham-na prisioneira na composição desta peça. Já Boulez reconhece no Quarteto uma peça que transmite ao gênero música de câmara elementos modernos, libertando-o de tradicionais amarras formais. 


\title{
Herbert Eimert, Debussy's “Jeux”: novas propostas de abordagem analítica
}

Herbert Eimert, no artigo Debussy's Jeux, aborda questões essenciais para a compreensão do papel de Debussy como referência conceitual para compositores da segunda metade do século XX. Até então, embora Debussy fosse reconhecido como um dos pilares da música moderna no período pós-guerra, sua contribuição para a modernidade não era considerada tão radical quanto a de Schoenberg ou Stravinsky, ficando restrita a aspectos pontuais como o emprego de escalas de tons inteiros, escalas octatônicas, acordes de nona não resolvidos, tríades e tétrades sobrepostas.

A contribuição de Debussy não se resume ao uso dessas estruturas harmônico/escalares, embora isso tenha sido uma contribuição importante para as gerações subsequentes. É com essa problemática em mente que Eimert busca compreender o papel de Debussy entre os "grandes renovadores da música". Para Eimert, no balé sinfônico Jeux, obra onde o emprego dessas coleções escalares é um dado secundário, há elementos fundamentais que devem ser considerados como modelo de renovação estética/formal.

\begin{abstract}
Apenas recentemente o balé Jeux de Claude Debussy foi reconhecido como uma das obras mais importantes no início do desenvolvimento da música moderna. A razão para esta reavaliação não é imediatamente aparente, pois Jeux não parte do estilo normal de Debussy. Nenhum de seus recursos musicais está fora de sua linha geral de desenvolvimento, nenhum deles é novo, sensacional, revolucionário ou como quer que se chamem as novas radicais características de obras como Sagração da Primavera de Stravinsky ou Pierrot Lunaire de Schoenberg, escritos aproximadamente no mesmo período. Debussy é o menos revolucionário entre os grande renovadores da música. Mais do que qualquer homem ele alterou o seu ambiente musical, a música do fim do século XIX. Mas ele não se rebelou contra seu ambiente musical, ele o transformou delicadamente e com firmeza, alterando seu conteúdo de tensão. [...] É possível perceber o que a forma em Debussy não é; muito mais difícil é dizer o que ela é. Tem-se pouco progresso ao aplicar a música de Debussy a conceitos padronizados de teoria musical. É um erro mesmo se referir a temas, períodos ou parágrafos. O mesmo aplica-se a esquemas tonais tradicionais. Para descrever a música de Debussy, uma camada intermediária de conceitos flutuantes teria de ser especialmente descoberta. (EIMERT, 1961, p.3)
\end{abstract}

A preocupação de Eimert no artigo é apontar a necessidade de criação de novos conceitos para discutir a música de Debussy, que se encontra ao mesmo tempo ancorada no "ambiente musical do final do século XIX" e impossível de ser explicada pelo arcabouço teórico existente, na época, para a música desse período (como pudemos observar pela imprecisão da breve análise de Lockspeiser). Sob este aspecto, as 
características formais de Jeux são elementos de destaque, pois a partir deles Eimert é capaz de traçar importantes perspectivas analíticas:

[Jeux possui] uma desconcertante e vexante forma se nos apegamos às ideias tradicionais de estrutura e tematicismo, mas [é] um verdadeiro golpe de mestre se conhecemos o princípio de "variação sem fim" de Debussy que ele aqui, mais do que em qualquer outra obra, tornou real e levou a seu objetivo. O manejo da forma por Debussy é por meio de uma retirada - ele a reduz a movimentos de ornamento, motivos e flocos, que têm um poder associativo secreto tão grande que parece que é por sua vontade que se ergue um ato capaz de construir uma forma. [...] O que é retirado aqui é o expansivo século XIX de música. Todo compositor do século XX preocupa-se com isso. Apenas dois deles retiraram algo além do som: Debussy e Anton Webern. Em Jeux, Debussy reduz não seu som, mas a função de uma forma tradicionalmente construída. (EIMERT, 1961, p.4)

A redução da função de uma forma tradicionalmente construída em Jeux é acompanhada por outros tipos de redução dentro do âmbito melódico. Naturalmente, outros elementos surgem apresentando importância estrutural e suprindo a falta dos aspectos formais mencionados.

Se ainda podemos localizar "temas", eles não estão mais completos, mas sim literalmente divididos ao meio. E os motivos não são mais "trabalhados", eles possuem seu papel na coloratura ornamental linear, que é combinada com o papel do timbre para formar a unidade mais perfeita. Debussy funde categorias de forma, produzindo figuras cuja função musical ele chamou de "tempo ritmicisado". Nestes sons ritmicisados, o timbre funciona como uma categoria integral de forma. $\mathrm{O}$ movimento e o timbre de um som não podem ser separados; as curvas cinéticas do tempo são coloridas - isso vai muito além de Wagner e além do abafado som da música impressionista. (EIMERT, 1961, p.4)

Esse trecho é de suma importância pois apresenta, segundo Eimert, alguns dos principais elementos que fazem da obra de Debussy um dos pilares da música moderna (e a afastam, consequentemente, de Wagner e do meio impressionista francês): a utilização do timbre e da ornamentação como elementos estruturais na composição musical. Essa é uma característica que parece ter escapado a visões como a de Lockspeiser sobre a música de Debussy (ou, se a perceberam, não foram capazes de demonstrar de fato como tais procedimentos ocorrem, como faz Eimert no artigo). Alguns elementos estruturais que eram considerados pela geração de Eimert como ultrapassados também são observados em Jeux - possivelmente são os responsáveis por caracterizar Debussy como um "renovador da música do século XIX”. Aqui esses elementos encontram-se aliados ao que ele chama de princípio de "variação sem fim": 
Ao mesmo tempo, a tradicional previsibilidade da música não é sacrificada. Em Jeux, o repertório de temas e motivos é consideravelmente maior do que em uma prática formal habitual. Estas figuras são geralmente repetidas uma ou duas vezes, e então submergem. A repetição garante compreensibilidade no sentido mais aceito, mas a incompreensibilidade aumenta na medida em que o material repetido é constantemente novo. Estas justaposições funcionam de forma linear, direta. Elas são libertadas de um enquadramento, a rede de referências encontrada em formas dialeticamente organizadas, para formarem ondas ornamentais lineares, que por sua urgência dinâmica não são nem guiadas para definir um objetivo nem representam uma decoração simplesmente imposta; elas são fluxo e forma ao mesmo tempo. (EIMERT, 1961, p.6)

Mais uma vez observamos um elemento não tradicional atuando de forma estrutural em Debussy: a manipulação de materiais novos e repetidos, ao mesmo tempo mantendo uma previsibilidade tradicional e atuando como "ondas ornamentais lineares", levando o conceito de forma para outro patamar, o de forma como fluxo.

Mesmo que o artigo de Eimert não faça menção ao Quarteto, é interessante destacarmos alguns de seus conceitos analíticos, pois entre as diversas características apontadas por Eimert, observamos algumas que serão exploradas de forma exaustiva por autores estudados neste trabalho. Nesse sentido, o Quarteto de Debussy é uma peça interessante de se observar, não por ter processos composicionais semelhantes aos de Jeux; afinal, tratam-se de obras separadas por quase vinte anos, o que em Debussy representa praticamente toda a sua carreira ${ }^{5}$. Porém, passados mais de cinquenta anos após a publicação do texto de Eimert, muitas técnicas analíticas foram desenvolvidas e elucidaram diversos procedimentos por ele apontados, com metodologias claras e demonstrando que muitas dessas características já se encontram em peças anteriores a Jeux (Quarteto incluído aqui), mesmo que em estado embrionário ${ }^{6}$.

5 O Quarteto foi composto em 1893, enquanto Jeux data de 1912. Levando em conta que a última peça de Debussy data de 1916 e as primeiras peças maduras do compositor datam de 1890, é possível afirmar que tratam-se de peças em polos opostos de sua carreira.

6 Fundamental mencionar o livro Estética da Sonoridade (GUIGUE, 2011), que também parte de uma concepção próxima do serialismo para criar sua metodologia analítica para a música de Debussy. Guigue estabelece diferentes parâmetros musicais de naturezas distintas, observando de que maneira cada um se modifica com o decorrer da peça. A teoria do autor se encontra formulada apenas para peças de piano com o objetivo de reduzir a quantidade de parâmetros trabalhados (ao retirar diferenças de timbre, impossíveis de se realizarem ao instrumento), porém se trata de um livro essencial para uma compreensão da maneira como elementos não tradicionais possuem papel estrutural na música de Debussy. 


\section{A utilização de ferramentas analíticas da segunda metade do século $\mathrm{XX}$ aplicadas ao Quarteto de Debussy}

Se ao longo da segunda metade do século XX existia uma tendência a valorizar as características não tonais de obras de Debussy (ou a dar valor a suas obras menos ligadas ao tonalismo), o livro The Music of Claude Debussy de Richard Parks trouxe importantes contribuições para estabelecer uma relação equilibrada entre a valorização de elementos tonais e não tonais em sua música. Parks parte de uma premissa bastante ampla para realizar a sua pesquisa, colocando a seguinte questão como fundamental: "qual é a natureza do meio musical e dos recursos da música de Debussy, e como eles são empregados para gerar sua superfície musical em toda sua riqueza e diversidade?" (PARKS, 1989, p.IV). Uma investigação sobre a maneira como elementos ligados ao tonalismo atuam em suas composições é essencial para que esta questão seja elucidada.

No livro, Parks analisa peças de todos os períodos de composição de Debussy para diversas formações instrumentais, e a abrangência de suas análises faz com que se trate de uma das mais importantes obras analíticas sobre o compositor.

\section{Debussy e a condução melódica e harmônica a partir da ideia de prolongação}

Duas das principais metodologias analíticas empregadas pelo autor são a teoria dos conjuntos aplicada à música e análises prolongacionais baseadas na teoria schenkeriana $^{7}$. Com relação a esta última, Parks julga que, mesmo que ela tenha sido concebida com outro repertório em mente, é útil para alguns aspectos da música de Debussy. Porém, importantes elementos pertencentes a esta teoria não são encontrados na música do compositor, o que fortalece a ideia de que o tonalismo não é tratado de acordo com seus princípios tradicionais em suas composições.

7 Para que fosse possível utilizar a teoria schenkeriana em músicas da primeira metade do século XX foi necessária uma importante atualização de seus conceitos, pois a teoria foi originalmente concebida para músicas com características majoritariamente tonais, não sendo utilizada para analizar obras anteriores a compositores barrocos nem posteriores a compositores românticos. A atualização de seus conceitos, realizada a partir da década de 1960 por nomes como Wallace Berry e Felix Salzer, é fundamental neste sentido, e Richard Parks menciona o livro Structural Functions in Music de Berry (Englewood Cliffs, New Jersey: Prentice-Hall, 1976) como responsável por "estimular seu pensamento sobre aspectos não relacionados às classes de alturas e proporcionar soluções práticas para problemas analíticos" (PARKS, 1989, p.335). 
Muitas das características da prática comum do tonalismo reveladas de modo tão eloquente pela teoria schenkeriana simplesmente não são encontradas na música de Debussy. Talvez a mais visivelmente ausente seja a Urlinie; raramente se encontra uma linha de soprano que começa em um membro da tríade da tônica e desce, juntamente com a obra, para a própria tônica, apesar de existirem algumas raras composições do começo de sua carreira (como as Arabesques para piano solo) que sejam exceções. A ausência de uma Urlinie descendente é acompanhada por uma ausência de relacionamentos harmônicos baseados em quintas estruturais. Após as primeiras obras, raramente se encontram encerramentos de dominante-tônica em um sentido estrutural. Em termos schenkerianos, isso significa que o arpejo do baixo não é uma característica estrutural integral que permeia tudo. Progressões lineares são muito menos comuns do que em obras de mestres dos séculos XVIII e XIX, assim como o são as concatenações de relacionamentos contrapontísticos e harmônicos em camadas que normalmente as acompanham. Em Debussy, a progressão linear tende a ser do tipo mais simples e somente de significância local. Níveis estruturais são poucos e não são complicados; um gráfico de primeiro plano e dois gráficos de planos intermediários costumam ser suficientes para representarem as matrizes tonais, mesmo em peças maiores. Também existe uma disparidade entre o primeiro plano e níveis mais profundos que favorecem o anterior em riqueza de relações. (PARKS, 1989, p.4)

Outro importante problema com relação ao uso de análises schenkerianas para a música de Debussy é o fato de que, nessas análises, o cromatismo sempre se encontra em uma posição subordinada com relação às estruturas diatônicas, servindo para reforçar a tônica ou enriquecê-la. Para o autor, o cromatismo funciona de forma diferente na música de Debussy, não necessariamente cumprindo as funções mencionadas (PARKS, 1989, p.4-5).

Com relação ao Quarteto, Parks apresenta gráficos prolongacionais do primeiro movimento, atendo-se, em um primeiro momento, a uma leitura exclusivamente tonal/schenkeriana da obra (Figura 3 ). 


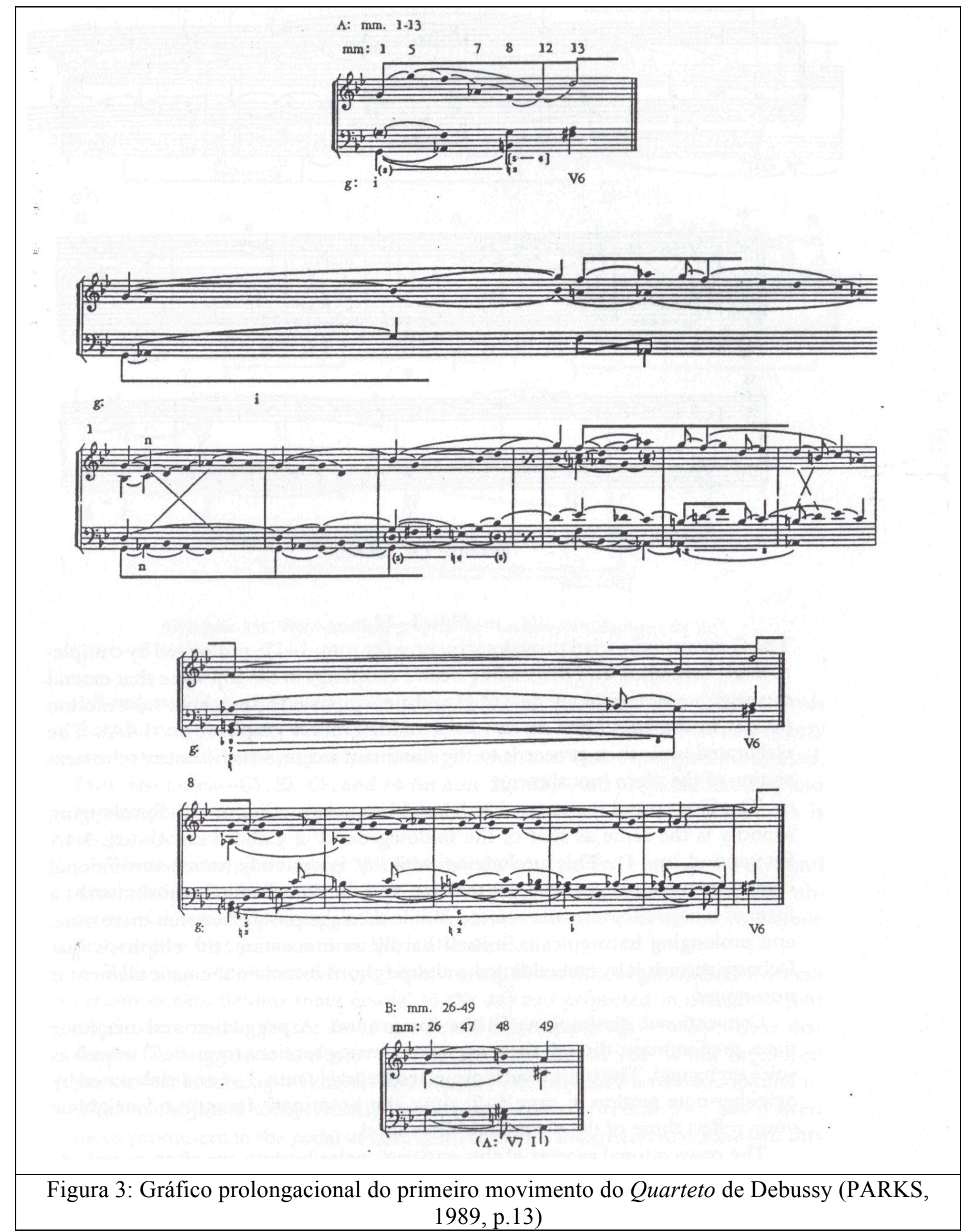

A reflexão de Parks sobre a figura acima enfatiza os problemas apresentados quando se busca coerência a partir de uma leitura tonal do Quarteto:

A tríade de sol menor provê a estrutura para os cc.1-12, prolongada por agrupamentos de oitavas ascendentes e descendentes na voz superior que estendem a prolongação por notas vizinhas de sol e são sustentadas pelo movimento por nota vizinha do baixo (para láb). A tônica elaborada então procede para a dominante maior, que controla a próxima seção da peça. 
O primeiro plano é saturado por movimentos por grau conjunto, e a sonoridade prolongacional é a mesma que a do plano intermediário: um acorde ${ }_{3}^{6}$ em lá bemol. Esta sonoridade prolongacional é certamente uma escolha não convencional. Sua raiz "subtônica" não reforça a tônica, e a terça menor do acorde evoca um tipo de mistura que é bastante remota. Mesmo que o relacionamento entre esta tônica e sua harmonia de prolongação não seja uma inovação, a ênfase que Debussy dá, inserindo acordes alterados em um elemento temático principal, é incomum.

Diminuições convencionais preenchem o primeiro nível. Graus conjuntos e arpejos predominam, apesar de haver alguns movimentos de passagem (cc.6-7) e trocas de vozes. A tríade da tônica é projetada claramente nos cc.1-4 e elaborada por movimentos de grau conjunto nos cc.5-7; desta forma, graus conjuntos proeminentes em um primeiro nível refletem aqueles presentes em níveis intermediários, mais profundos. (PARKS, 1989, p.12)

Esta sonoridade prolongacional mencionada por Parks é considerada como uma característica não convencional do trecho, assim como o é a “importância desproporcional dada à sétima e à nona nos cc.8-12 em relação ao sol no baixo". Neste trecho,

O cromatismo (terçar maiores, sétimas e nonas bemóis) dá o efeito de uma sonoridade de dominante com nona sem evocar uma função de dominante com nona. [...] O tratamento de sua dominante com nona revela um compositor cuja obsessão por sonoridades pelo seu próprio valor o tenta a sobrepor relações mais fortes no âmbito da harmonia e encaminhamento de voz. (PARKS, 1989, p.13)

Em sua análise, Parks aprofunda-se sobre os cc.1-12 e cc.26-33, dois trechos em que existe a presença do primeiro elemento temático. Na segunda passagem, na qual observamos reinterpretações harmônicas do primeiro tema que trazem mudanças significativas, também observamos uma "importância especial dada à sonoridade em relação às necessidades de encaminhamentos de vozes diatônicas". Na análise deste trecho, Parks apresenta uma importante visão sobre a maneira como dissonância e consonância se relacionam com a nossa percepção, contribuindo para uma melhor compreensão do papel que o tonalismo ocupa no Quarteto:

Debussy trata seu primeiro plano com cuidado: uma sétima geralmente se resolve por grau conjunto em direção a sua inflexão, assim como ao menos um dos membros do trítono; se não, esta altura continua na próxima harmonia, na qual é reinterpretada como um membro estável do acorde. [...] Mas esta aparente preocupação com detalhes do primeiro plano esconde um tratamento mais casual do encaminhamento de vozes em planos mais profundos, uma vez que a reinterpretação (em vez de resolução) de uma dissonância força o ouvinte a abandonar expectativas habituais de encaminhamento de voz. A reinterpretação consoante de uma dissonância pode amenizar a tensão esperada por um ouvinte habituado ao tonalismo, mas também impede que a habilidade de tal tensão comunique a presença de intervalos cruciais com funções especiais no 
encaminhamento de vozes. Se dissonâncias em um plano médio ajudam o ouvinte a navegar por jornadas tonais em espaços temporais mais longos, a reinterpretação (em vez de resolução) torna essas jornadas menos compreensíveis. O tratamento não ortodoxo de dissonâncias por parte de Debussy (dissonâncias que são fortemente projetadas por cromatismos e síncopas) proporciona uma aura superficial que se assemelha a um território tonal familiar, mas as relações mais profundas revelam a estranheza deste ambiente. (PARKS, 1989, p.13)

No trecho citado fica claro um aspecto importante para o ponto de vista analítico de Parks: funções tonais da dissonância, que podem ser vistas por meio do encaminhamento de vozes, deixam de ter importância a partir do momento em que elas são reinterpretadas de forma consonante no próximo acorde. Este é um dos aspectos responsáveis pelo que ele chama de "sonoridade pelo seu próprio valor", em detrimento de relações no âmbito harmônico e de encaminhamento de vozes.

Parks (p.14) apresenta os compassos 34-47 como "tonalmente intrincados, que também ilustram de que maneira o cromatismo reflete o pouco caso de Debussy com encaminhamentos de vozes em níveis intermediários em favor de uma sonoridade na superfície", reforçando o que já foi observado em trechos anteriores de sua análise:

A forma espaçada dos níveis estruturais de ambas as passagens contrasta fortemente com o cromatismo complexo de seus encaminhamentos de vozes, e progressões lineares são visivelmente ausentes. O resultado é uma superfície musical rica, na qual falta a qualidade dinâmica de um movimento para a frente ao qual estamos acostumados em nossa experiência com a musica tonal anterior (PARKS, 1989, p.14).

Nos exemplos anteriores, Parks aprofunda-se sobre aspectos tonais do Quarteto e de que maneira estes podem ser observados sob um ponto de vista schenkeriano. Tais exemplos reforçam a ideia de que existe uma incompletude deste tipo de análise para explicar a música de Debussy.

Sob uma perspectiva schenkeriana, anomalias tonais ocorrem em todos os níveis estruturais: na utilização não usual de misturas na primeira passagem, na falta de progressões lineares no plano médio e na prolongação do primeiro grau da escala (uma altura que não vai a lugar nenhum) como primeira altura primária de ambas as passagens (PARKS, 1989, p.14).

Observaremos, a seguir, de que maneira o autor aborda elementos não tonais presentes no Quarteto. 


\section{O Quarteto sob uma perspectiva da teoria dos conjuntos}

Quando a teoria dos conjuntos aplicada à música foi introduzida como metodologia analítica, sua utilização era restrita à música serial, dodecafônica e atonal de modo geral, não se aplicando à música pós-tonal do final do século XIX e início do XX. Sua utilização para este tipo de música surge a partir da compreensão de que outras ferramentas analíticas não eram satisfatórias para solucionar todos os problemas encontrados, como foi possível observar no item anterior. Nesse sentido, o livro Introduction to Post-Tonal Theory (STRAUS, 2004) merece ser destacado, pois apresenta conceitos provenientes da teoria dos conjuntos aplicados à música pós-tonal (porém não atonal) do período de forma enriquecedora.

Para Richard Parks, ideias advindas da teoria dos conjuntos aplicadas à música mostraram-se de importância inestimável para explicar alguns aspectos relativos às

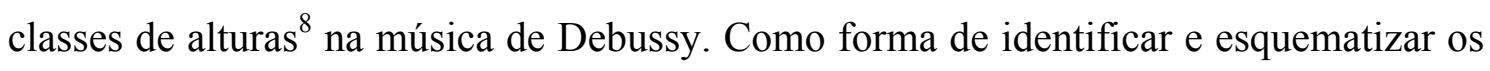
diferentes grupos de alturas presentes em sua música, o autor estabelece uma distinção entre quatro espécies de conjuntos de classes de alturas ${ }^{9}$, com as quais é possível observar uma importante mudança entre um uso mais direto e óbvio das diferentes espécies em suas primeiras obras de maturidade e uma utilização mais sofisticada destas em suas últimas composições (PARKS, 1989, p.47).

As quatro espécies de conjuntos de classes de alturas são as diatônicas (7-35), os tons inteiros (6-35), as octatônicas (8-28) e as cromáticas (estas não possuem apenas uma única série de conjuntos, porém um núcleo de cinco séries pode ser considerado como característico desta espécie: 3-1, 4-1, 5-1, 6-1 e 7-1). O Quarteto é a primeira obra de grande porte de Debussy em que Parks identifica este processo, pois mesmo dominada pela espécie diatônica, também encontramos nela exemplos de espécies octatônicas e de tons inteiros. No Quarteto, estas mudanças são observadas de forma bastante direta, o que é condizente com a maneira como Debussy utiliza diferentes espécies nesse período composicional. A figura a seguir apresenta três exemplos de

8 Neste trabalho empregaremos o termo classe de alturas para designar as notas musicais sem diferenciação de oitava. Por conjunto referimo-nos a uma série de classes de alturas, como foi concebida por Allen Forte e descrita em seu livro Structure of Atonal Music (FORTE, 1973).

$9 \mathrm{Na}$ atual compreensão da Teoria dos Conjuntos tais elementos são denominado como "coleções de referência", ou como "coleções específicas de classes de alturas referenciais", que é a expressão utilizada por Annie Yih, como observaremos posteriormente. 
mudanças entre espécies de conjuntos de classes de alturas no Quarteto, em que trechos octatônicos e de tons inteiros se encontram sempre entre dois trechos diatônicos.

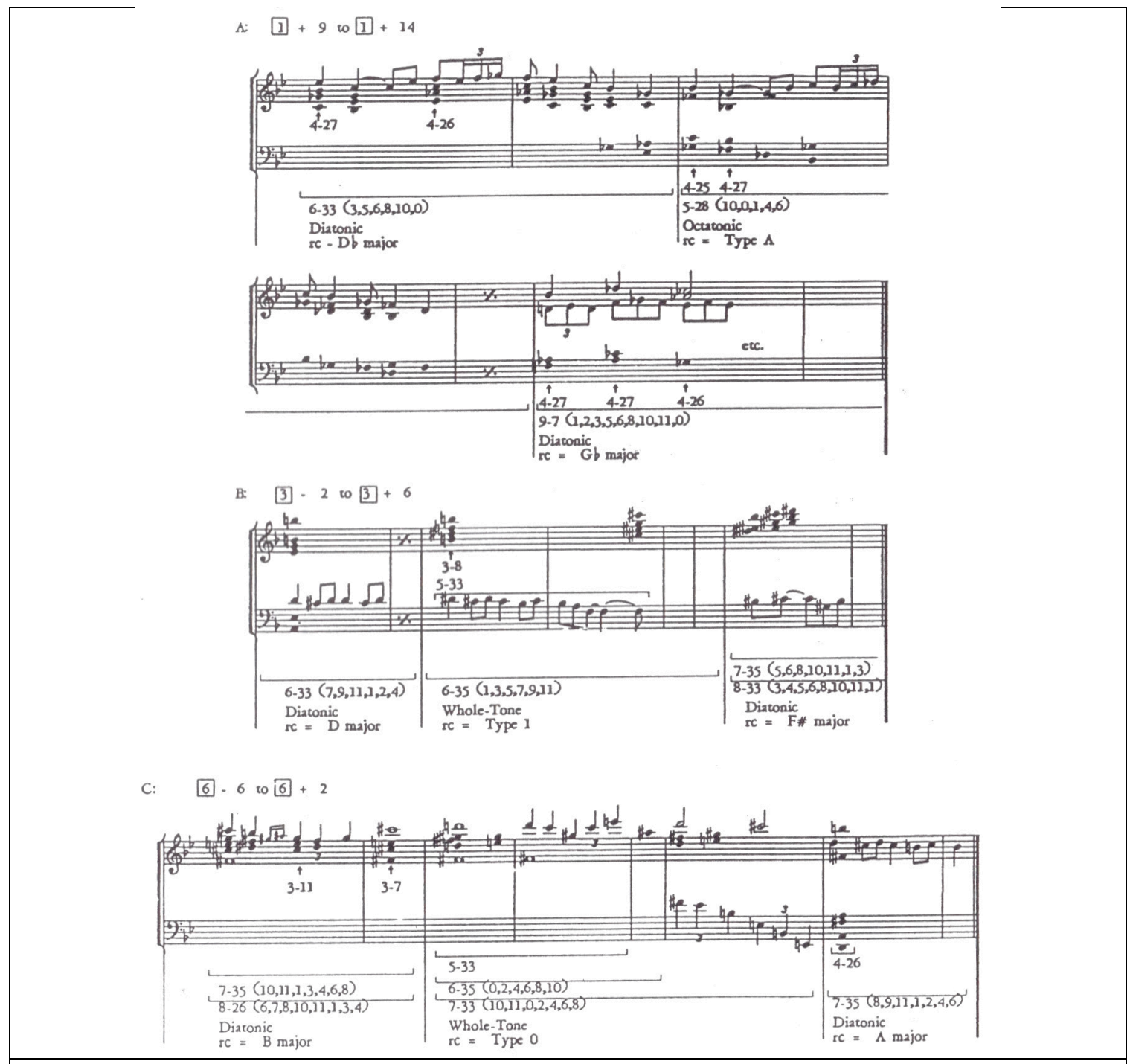

Figura 4: Exemplos da utilização de diferentes espécies de conjuntos de classes de alturas no Quarteto (PARKS, 1989, p.105)

A técnica de transformação de uma espécie a outra nos exemplos anteriores é sempre a mesma, com um ou mais elementos do conjunto sofrendo uma alteração de um semitom. Em B, observamos uma mudança das classes de alturas 2 e 4 para 3 e 5, transformando o hexacorde diatônico 6-33 no de tons inteiros 6-35. Então, as classes de alturas 6 e 8 são transformadas em 9 e 7, e a classe de altura 10 é adicionada, transformado a espécie de tons inteiros em diatônica novamente. $\mathrm{O}$ mesmo processo é 
observado em $\mathrm{C}$, onde as classes de alturas 0,2 substituem 1,3, passando de diatônico para tons inteiros ${ }^{10}$. Com esses exemplos, Parks chega às seguintes constatações:

Mudanças de espécies de conjuntos de classes de alturas criam contrastes sonoros gritantes que não são possíveis apenas dentro da espécie diatônica, e a localização das mudanças é crucial, pois, invariavelmente, elas precedem (e por consequência capturam a atenção do ouvinte para) importantes ligações formais. A passagem A [Figura 4] ocorre no final do primeiro grupo temático e é seguida da apresentação inicial do segundo tema (caracterizado por mudanças na dinâmica, articulação, figuração e espaçamento de registro). O material de tons inteiros da passagem B é suportado por mudanças no tempo, intensidade dinâmica, articulação, textura e tessitura aguda. Estas características são combinadas com mudanças no material de classes de altura para criar um momento de intensidade pouco usual logo antes do clímax do desenvolvimento.

O uso de espécies de conjuntos de classes de alturas em obras de início de sua carreira mostra Debussy desenvolvendo procedimentos para estabelecer e interrelacionar as diferentes espécies de conjuntos como um recurso para criar contrastes sonoros e meios de coerência que são combinados com meios harmônicos, temáticos e cinéticos. Existem também evidências de sua preocupação em integrar estes novos recursos com outros parâmetros musicais. No quarteto, a colocação de espécies não diatônicas é consistentemente conectada com a localização de importantes junções formais. (PARKS, 1989, p.104-105)

Tal constatação é de grande importância para esta pesquisa, pois boa parte dos trechos escolhidos para uma análise aprofundada também se localiza ao final de junções formais. Observaremos que mudanças presentes em "outros parâmetros musicais" que acompanham as mudanças harmônicas descritas por Parks possuem um grande nível de complexidade e serão uma das ênfases deste trabalho.

Annie Yih, Analysing Debussy: Tonality, Motivic Sets and the Referential PitchClass Specific Collection - ênfase na elaboração motívica

O artigo Analyzing Debussy: Tonality, Motivic Sets and the Referential PitchClass Specific Collection (YIH, 2000) aborda didaticamente a questão do emprego de materiais tonais no Quarteto de Debussy :

$\mathrm{Na}$ análise de obras que empregam diatonismo, mas são permeadas por sonoridades "experimentais" proeminentes que não podem ser facilmente explicadas em termos

10 Este tipo de procedimento também é identificado por Annie Yih, que o classifica como "substituição de classes de alturas", como observaremos a seguir. 
tonais-funcionais, a questão do tonalismo é complexa. Na música de Debussy da virada do século é fácil assumir que a mera presença de elementos tonais traz unidade e coerência. Porém, assumindo elementos tonais como básicos e relegando outros elementos de alturas a um papel ornamental, a importância de sonoridades inovadoras e de encaminhamentos de vozes não convencionais pode ser subestimada, forçando-os a caber em um modelo a priori tonal. Em outras palavras, colocando um relacionamento hierárquico entre diatonismo e cromatismo em sua musica, pode-se desatentar para a possiblidade de que as chamadas características "experimentais" tenham de fato um papel estrutural. Coerência na música de Debussy não precisa ser explicada exclusivamente em termos tonaisfuncionais. (YIH, 2000, p.203)

Comparando a afirmação acima com os pontos de vista observados nas análises de Parks e Eimert, é possível afirmar que Yih vê no Quarteto de Debussy um conceito analítico semelhante ao observado por Eimert em Jeux. Ou seja, a estrutura do Quarteto baseia-se em elementos não tonais, embora possam encontrados elementos tonais em sua construção.

Yih apresenta uma análise inspirada no método schenkeriano ${ }^{11}$ para demonstrar como a abordagem analítica tonal do Quarteto resultaria em uma visão incompleta dos aspectos mais essenciais da obra. A análise de Yih amplia a visão de Parks pois, enquanto Parks se atém a trechos pertencentes a um plano formal intermediário, Yih apresenta um gráfico que engloba todo o primeiro movimento. A partir da estratégia analítica de Yih é possível observar que as mesmas observações realizadas por Parks se aplicam a um plano formal em larga escala: não é possível encontrar elementos tonais que proporcionem à peça unidade orgânica.

11 Segundo Yih, tal leitura é possível a partir do momento em que se aceita a nota sol como centro tonal do primeiro movimento, no qual o mi bemol também possui papel relevante, chegando a haver, segundo a autora, uma possível ambiguidade tonal entre as duas notas como centros. 


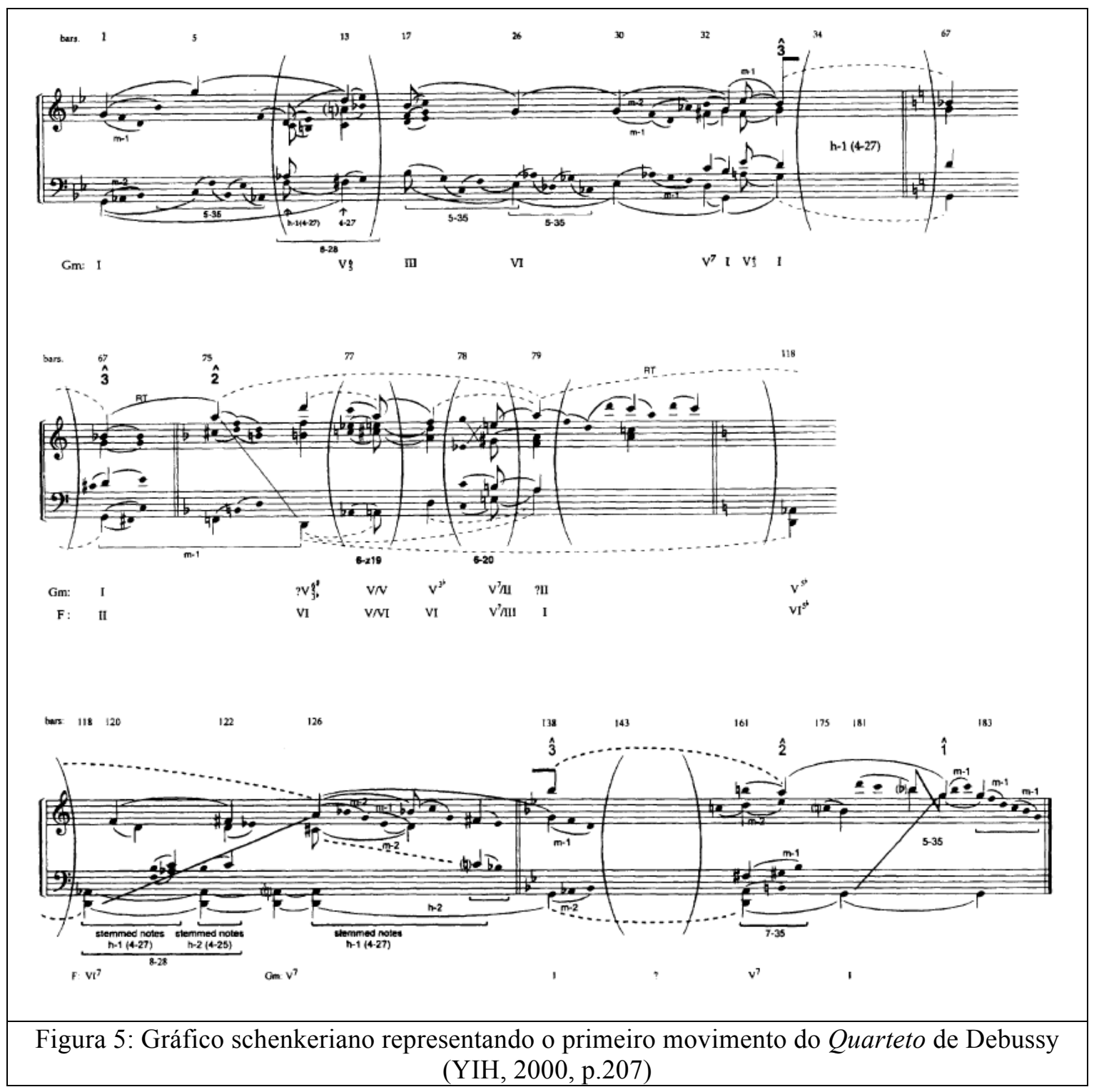

$\mathrm{Na}$ análise da Figura 5, a autora apresenta dois exemplos em que uma progressão em terças em larga escala pode ser identificada. No primeiro caso (c. 138), î está em uma voz interna, uma vez que a segunda ocorrência de $\hat{3}$ está na voz superior. Porém, as duas progressões em terça não são eventos em primeiro plano pois não são sustentadas por expansões motívicas e harmônicas constitutivas de uma Urlinie. Dessa forma, compreender o movimento como um $\hat{3}, \hat{2}$, parte de uma Urlinie $\hat{3}, \hat{2}, \hat{1}$ é um erro, pois força a leitura a adequar-se a um paradigma. Assim, mesmo que a peça traga características tonais, uma explicação tonal baseada em uma unidade orgânica não é possível (YIH, 2000, p.208).

Outros pontos observados no gráfico acima que deixam clara a incompletude deste método analítico para esta peça são os longos trechos entre parênteses, que só podem ser explicados por meio de um tonalismo modificado e interrompem uma 
progressão harmônica contínua. Estes trechos possuem material de grande importância nesta peça, o que faz com que sua ausência seja problemática em um nível estrutural. Características motívicas de sonoridade não tonal também teriam de ser reduzidas a elementos não estruturais, o que é igualmente insatisfatório.

Segundo Yih, é central para a teoria schenkeriana a ideia de unidade orgânica em níveis locais, de média e larga escala - de diminuições melódicas da linha fundamental mutualmente corroborativas, que são encontradas em membros da tríade da tônica. No Quarteto, a unidade em um nível médio depende de relacionamentos que não são característicos da teoria tonal, o que torna incompleta uma leitura feita a partir de referências exclusivamente tonais.

Porém, a autora defende que uma análise baseada somente em características não tonais da peça por meio da teoria dos conjuntos aplicada à música tampouco seria satisfatória para explicar o Quarteto. Mesmo que esta teoria tenha a vantagem de ser autorreferencial, ou seja, não precise levar em conta hierarquias entre alturas e seja capaz de revelar uma série de redes de associações de conteúdo intervalar, ela não leva em conta importantes características tonais presentes no Quarteto, assim como uma análise schenkeriana ou funcional não levaria em conta a presença de elementos “experimentais" na peça. É preciso que se tenha uma "aproximação analítica que seja sensível a todos os aspectos de suas qualidades sonoras" (YIH, 2000, p. 208).

Para solucionar este problema, a autora propõe uma teoria na qual o Quarteto se encontra fundamentado em uma coleção de alturas diatônicas e os diversos conjuntos de alturas na peça são vistos como "subgrupos motívicos referenciais" que se relacionam com esta coleção diatônica. Desta forma, consideram-se os diferentes materiais unificados, ou seja, gerados a partir de uma mesma fonte e integrados por um material motívico em comum. Dois processos transformacionais são identificados pela autora, relacionando-se com o material da peça: a substituição de classes de alturas e a transformação por encaminhamento de vozes.

Substituição de classes de alturas é o processo de substituir uma altura por outra em uma harmonia ou coleção de alturas. Apesar de este processo ser similar ao conceito de Schoenberg de "transformação" - que ele define como o uso de notas cromáticas para substituir notas diatônicas com o objetivo de expandir harmonias tonais -, a substituição de classes de alturas neste estudo não se restringe a formulações tonais. A transformação por encaminhamento de vozes descreve a transformação de uma ou mais alturas em uma harmonia que tem importância motívica, resultando em outra harmonia que é transposicionalmente - ou inversamente - relacionada à original. [...] Por meio destes dois processos, o 
compositor cria novas sonoridades harmônicas que são desenvolvidas, enfatizadas e projetadas por meio de repetições, sequências, paralelismo de acordes e outros processos transformacionais ${ }^{12}$. (YIH, 2000, p.209-210)

Yih classifica como transformação por encaminhamento de vozes processos em que um grupo de notas, por exemplo, ré, fá, láb e dó, sofrem transformações cromáticas, com ré e dó movendo-se para mib e si, respectivamente. De forma não ordenada, o novo acorde, mib, fá, láb, si, relaciona-se com o original por meio de transposição.

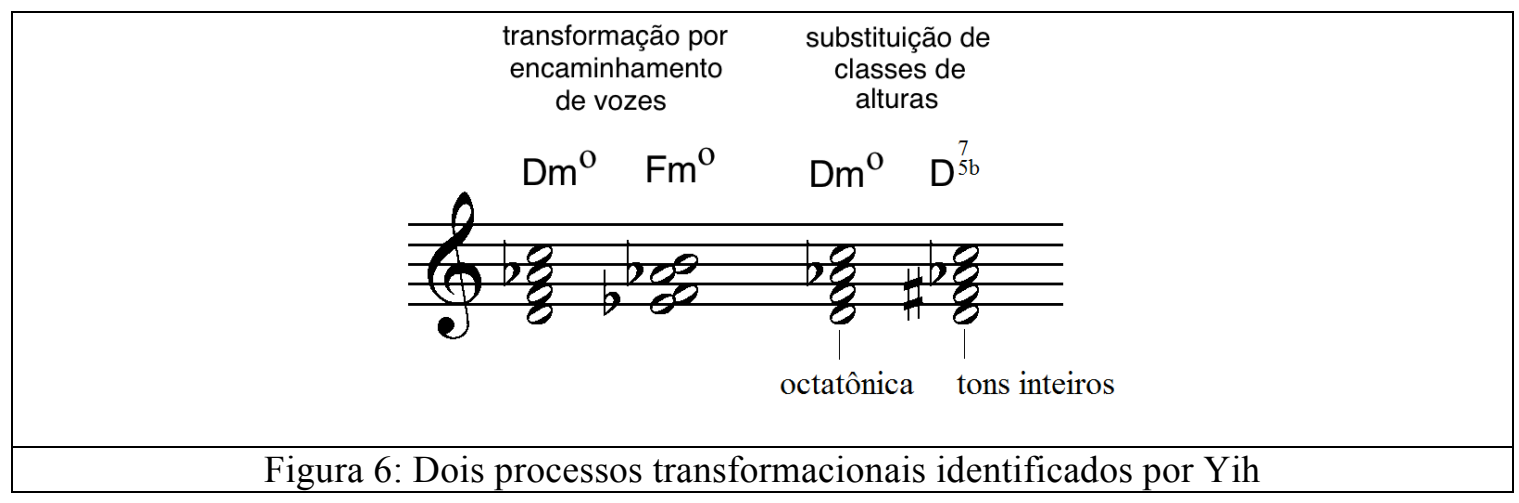

O processo de substituição de classes de alturas também se relaciona com a maneira como uma "espécie de grupo de classes de alturas" de Parks se transforma em outra, o que fica claro na Figura 6 , na qual um grupo pertencente à espécie octatônica se transforma em um grupo pertencente à espécie de tons inteiros por meio da substituição de uma classe de altura do tetracorde (fá por fá\#).

A autora enfatiza a importância, nesta análise, de motivos que são subgrupos de uma coleção diatônica referencial. Yih denomina esta coleção diatônica como "coleção específica de classes de alturas referenciais" (RPSC, sigla em inglês), ou seja, o conjunto de classes de altura considerado como referência para a composição musical. Neste caso, a RPSC é formada pelas notas pertencentes à escala de sol menor, e todos os motivos observados por Yih são pertencentes a esta escala ou transformados dela a partir dos processos apontados anteriormente. A figura a seguir apresenta os quatro principais motivos identificados pela autora, dois melódicos e dois harmônicos, base para parte importante do material motívico e harmônico desta peça.

12 Os dois processos mencionados, principalmente o de transformação por encaminhamento de vozes, são advindos da teoria neo-reimenniana, com frequência aplicada na música do fím do século XIX (período em que viveu o próprio Reimann). A autora menciona, inclusive, a semelhança entre seus conceitos e o de injection function de David Lewin, um dos principais responsáveis pela solidificação desta teoria ao longo da década de 1980 e 1990. 


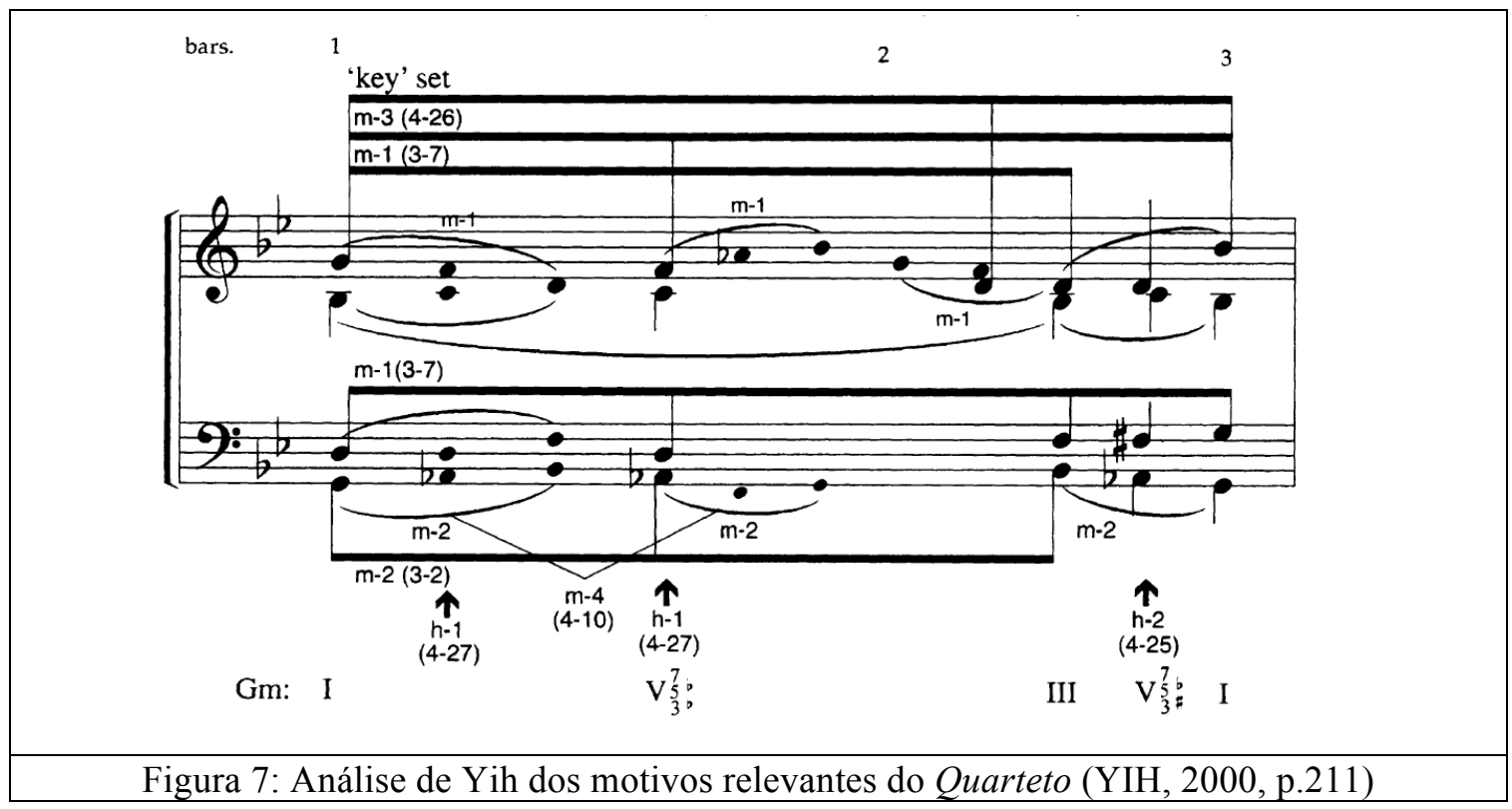

A identificação dos dois motivos lineares depende de vários fatores: ambos aparecem nas vozes extremas, em contraponto uns aos outros e sua importância é enfatizada pela repetição imediata e reaparição na mesma parte instrumental; m-1 encontra-se retrogradado em sua repetição, e m-2 invertido, transposto e reordenado. Encontramos exemplos de m-1 e m-2 em diferentes planos formais na figura acima, ocupando por vezes menos de um compasso mas também em espaços maiores, com mais de dois compassos.

Já a significância motívica de h-1 encontra-se no fato de ser por meio de substituições ou transformações de encaminhamento de vozes deste acorde específico que são formados outros motivos harmônicos não pertencentes às "classes de alturas referenciais" $"$. Um primeiro exemplo desta transformação é o motivo h-2, gerado a partir da substituição do fá natural pelo fá sustenido (Figura 6).

A partir dos motivos presentes na figura acima, Yih demonstra, em uma grande quantidade de exemplos, de que maneira as alturas da peça são interligadas de forma motívica. Assim, mesmo que uma leitura exclusivamente tonal de alguns trechos do primeiro movimento (como os cc.1-33) seja possível, a aproximação motívica proporciona uma leitura mais unificada de todo o material de alturas da música, seja ele diatônico, octatônico em tons inteiros ou não tonal.

13 Desta forma, h-1 destaca-se por ser a primeira ocasião em que encontramos notas não pertencentes a esta RPSC, e por ser por este grupo de notas que se realizam transformações para outros motivos não pertencentes à RPSC. 
A autora defende que a geração de elementos octatônicos, de tons inteiros e de conjuntos de alturas não tonais é feita a partir da RPSC diatônica e de seus subgrupos motívicos por meio dos processos observados anteriormente: substituições de classes de alturas e transformações de encaminhamentos de vozes. Esta é a base de sua teoria alternativa para explicar o relacionamento e a integração de diversos materiais de alturaS no Quarteto de Debussy, e tal leitura é feita a partir de aproximações analíticas lineares (derivadas de modelos schenkerianos) e da teoria dos conjuntos combinadas. Segundo Yih, este modelo revela a unidade motívica de diversos materiais de alturas de forma mais convincente do que qualquer método analítico individual.

O artigo de Annie Yih é um dos trabalhos que se dedica com mais profundidade ao Quarteto de cordas em sol menor de Debussy, e tanto a sua análise quanto a de Richard Parks contribuem de forma significativa com o campo analítico, ao conciliarem, de forma exaustiva, duas metodologias analíticas estabelecidas e habitualmente empregadas em músicas de períodos distintos.

Já a proximidade de Yih com o trabalho de Eimert dá-se, principalmente, pela ênfase na questão motívica e em colocar elementos não tonais como estruturais na composição musical. Porém, acreditamos que uma ênfase demasiada na estrutura harmônica desta peça pode ofuscar outros procedimentos presentes aqui que não se encontram neste campo. A própria Yih menciona que "o compositor cria novas sonoridades harmônicas que são desenvolvidas, enfatizadas e projetadas por meio de repetições, sequências, paralelismo de acordes e outros processos transformacionais"; porém, a autora não se aprofunda sobre de que maneira repetições podem agir sobre a estrutura da peça, nem que outros processos transformacionais podem existir. Esta busca será uma das ênfases desta pesquisa, como demonstrará o próximo capítulo. 


\section{Forma cíclica, forma cinética e o uso de reiterações}

\section{A forma cíclica e o Quarteto de cordas em sol menor de Debussy}

O conceito de forma cíclica apresenta importantes desafios ao pesquisador. Diferentemente de conceitos como o de forma sonata, estudado com exaustão desde meados do século XIX, existe menos material publicado sobre ela, consequentemente, há menos consenso ao falarmos em forma cíclica, o que faz com que o conteúdo sobre o qual nos debruçamos ao empregar este nome mude drasticamente dependendo do período histórico pesquisado. O que liga as diferentes definições é o fato de todas tratarem (em diferentes níveis) de relações temáticas ou motívicas, ou mesmo da semelhança entre diferentes temas dentro de uma mesma peça.

Neste trabalho, serão investigadas as perspectivas de quatro autores sobre o conceito de construção cíclica: James Webster (Haydn's “Farewell” Symphony and the Idea of Classical Style, 1991), Ivanka Stoïanova (Manuel D’analyse Musical, 2000), Charles Rosen (Sonata Forms, 1988 e A geração romântica, 2000) e Marianne Wheeldon (Debussy and the Cyclique Sonate, 2005). Entre estes autores, Webster e Stoïanova aprofundam-se sobre a forma cíclica no período clássico, Rosen estuda o tópico ao longo da geração romântica e Wheeldon comenta de que maneira Debussy adota Franck como modelo de forma cíclica na composição do Quarteto de Cordas em sol menor, entre outras peças do período.

Compreender de que maneira a ideia de construção cíclica é utilizada em diferentes períodos históricos e por diferentes autores enriquece a compreensão das possíveis influências de Debussy sob este aspecto, esclarecendo como atua um elemento determinante no processo composicional do Quarteto de cordas em sol menor, que é o uso de repetições temáticas e motívicas.

\section{Webster e a integração cíclica}

A visão de James Webster sobre o conceito de construção cíclica destaca-se das que observaremos adiante, possivelmente por se tratar do autor que pesquisa o tema em 
um período histórico mais antigo. Ao referir-se aos fenômenos cíclicos na Sinfonia "Farewell" de Joseph Haydn, Webster não remete ao uso recorrente de um mesmo tema em diferentes movimentos, como fazem não apenas os outros textos citados acima, mas também a Encyclopaedia Brittanica (2014) e o dicionário Grove de Música (2001, v.6, p. 797-798). Este tipo de recorrência, segundo Webster, não se encontra nem em Haydn nem na música instrumental do fim do século XVIII de modo geral, e "com exceção da noção lugar-comum de 'unidade dentro da diversidade', teóricos do fim do século XVIII não tinham vocabulário conceitual para descrever as relações de movimentos dissimilares separados pelo tempo" (WEBSTER, 1991, p.179).

Webster utiliza o termo "integração cíclica" para designar aspectos da construção musical e técnica como semelhanças entre materiais e relações tonais, e o termo "composição contínua" (trough-composition) para fenômenos de dinâmica ou gestuais como movimentos contínuos, retornos, instabilidades não resolvidas e falta de encerramento (WEBSTER, 1991, p.7). É possível associar a ideia de integração cíclica de Webster ao conceito de desenvolvimento motívico, em que fragmentos menores do que uma melodia completa são elaborados e apresentados diversas vezes em uma composição musical. Tal fato permite que se faça uma associação entre o que Webster denomina de integração cíclica e o que os autores posteriormente estudados aqui classificam como forma cíclica.

Antes de aprofundar-se sobre a composição cíclica em Haydn, James Webster levanta uma série de questões que são de grande importância, não apenas para a compreensão do papel do "ciclicismo" em Haydn, mas para a toda a compreensão analítica, com importantes implicações na maneira como podemos compreender, inclusive, a música de Debussy.

O que quer ser dito com a afirmação de que uma sinfonia de Haydn é unificada? Seria este sentido de unidade subjetivo, arbitrário, convencional essencialmente uma racionalização do status de favorito de uma obra privilegiada ou existe uma base psicológica identificável ou uma base técnica? Dada sua raiz intelectual em um pensamento organicista do fim do século XIX e começo do século XX, qual a razão para exigir "unidade" como uma constituinte da música instrumental do século XIX, ou mantê-la como uma categoria teórica hoje? Se, por outro lado, utilizarmos um termo como "coerência" ou outro termo menos carregado semanticamente, seriam os problemas eliminados, transferidos para um domínio menos obviamente questionável ou simplesmente obscurecidos por uma distinção semântica sem diferença? (WEBSTER, 1991, p.174-175) 
Mesmo que o autor não tenha a pretensão de responder tais questões, como ele mesmo afirma na sequência de seu texto, essa afirmação deixa claro que, para Webster, a ideia de que elementos cíclicos surgem com o intuito de proporcionar "unidade" dentro da música deve ser questionada ${ }^{14}$. As questões levantadas também são relevantes no contexto do Quarteto de Debussy: o que significa afirmar que existe unidade em sua obra? Já em uma primeira escuta é possível observar que existem importantes ligações temáticas, e a recorrência do primeiro tema em diferentes localidades da peça também liga diversos elementos. Porém isso é o suficiente para proporcionar unidade à música?

Para Webster, nas diversas composições de Haydn em que encontramos tais procedimentos existem três principais aspectos relevantes da organização cíclica de obras instrumentais do fim do século XVIII: "revogação da convenção de gêneros pela qual os movimentos são geralmente compreendidos como separados e distintos [...]; relação entre ideias musicais; e organização tonal (WEBSTER, 1991, p.175-176)". O contraste entre movimentos sucessivos, em que o tempo quase sempre muda e métrica e afeto são contrastados também é um princípio primordial de peças que utilizam esta construção (WEBSTER, 1991, p.176).

Neste contexto, o autor defende que os diferentes movimentos de uma peça que utiliza procedimentos cíclicos se comportam dentro de um número limitado de opções:

$\mathrm{R}$ (rápido) movimento de abertura (ou interno) rápido ou moderado em estilo sonata L (lento) movimento interno (ou de abertura) lento em estilo sonata

$\mathrm{M}$ ou TdiM minueto e trio ou tempo di menuetto

Var tema e variação

Canção A B A e similares

Fn rápido finale (geralmente mais leve que os movimentos anteriores)

FN finale denso (e.g. uma fuga)

Antes de comparar tais modelos com o Quarteto de cordas de Debussy, observaremos as definições de Ivanka Stoïanova sobre a construção cíclica: será possível notar que muitas das definições empregadas por Webster são confirmadas pela visão de Stoïanova, o que reforça a ideia de que ambos tratam do mesmo assunto, porém em estágios de elaboração diferentes.

14 Webster acredita que a melhor forma de realizar uma análise musical é de forma "multivalente", ou seja, estudar cada objeto principal (forma, ideias musicais, estrutura tonal, ritmo, instrumentação etc.) de forma independente, sem levar em conta a "unidade" ou o nível de congruência entre os padrões temporais (WEBSTER, 2004, p.4). 


\title{
A forma cíclica segundo Ivanka Stoïanova
}

Ivanka Stoïanova é mais explícita ao utilizar o termo "forma cíclica", enquanto Webster remete a "processos cíclicos". Em seu livro Manuel d'Analyse Musicale, a autora propõe uma sistematização relativamente rigorosa desta forma:

\begin{abstract}
A forma cíclica é composta por diversos movimentos distintos, em que cada um possui uma estrutura formal independente. [...] O princípio formador das obras cíclicas é o do contraste apesar dos elementos temáticos comuns: os movimentos, que diferem essencialmente no que diz respeito ao tempo e a sua fórmula de compasso, podem comportar similitudes temáticas e submeter-se obrigatoriamente a uma tonalidade principal ou a um plano tonal unificante, o que contribui para a coerência do ciclo em sua globalidade. (STOÏANOVA, 2000, p.165)
\end{abstract}

Observamos nessa citação diversas concordâncias com relação ao texto de Webster; ambos destacam a importância do contraste para o pensamento cíclico, mencionando mudanças de tempo e métrica entre andamentos. Também mencionam a importância da existência de alguma forma de organização tonal e de relações entre ideias musicais. Porém, para Stoïanova a forma cíclica surge com o objetivo de proporcionar unidade à música, e esta unidade é obtida de diferentes formas de acordo com o período de composição da obra. No primeiro período do Classicismo, "a unidade do ciclo da sonata [...] impunha-se exclusivamente pelo plano tonal". A partir do século XIX, eram as relações temáticas à distância que "permitiam uma estrutura audível da obra pelo jogo do mesmo tema em diferentes condições" (STOÏANOVA, 2000, p. 185), contribuindo para a coerência e centralização da obra em sua totalidade.

A mudança de paradigma na maneira de se obter unidade dentro da música passando da unificação tonal no período clássico para o uso de relações temáticas a distância no período romântico - é um aspecto formal relevante, pois o Quarteto de cordas de Debussy relaciona-se intimamente com ambas as características, como observaremos adiante.

Sendo o Quarteto de Cordas formado pelos movimentos Animé et très décidé, Assez vif et bien rythmé, Andantino doucement expressif, Très modérè, é possível compará-lo aos padrões formais descritos no item "Ciclo em quatro movimentos" do 
livro de Stoïanova ${ }^{15}$. Algumas possibilidades formais para a construção dos movimentos são apresentadas pela autora: o primeiro movimento pode ser estruturado como allegro de sonata, em ciclo de variações, em rondó lento (raramente) ou, excepcionalmente, como fuga. O segundo movimento pode ser um minueto ou um scherzo, ou ainda um movimento lento, fazendo do minueto ou scherzo o terceiro movimento. Sendo o segundo movimento um scherzo ou um minueto, sua tonalidade é habitualmente a principal e sua estrutura é uma forma tripartida complexa com trio, reprise da capo e coda (tardiamente, encontramos formas mais complexas neste movimento). $\mathrm{O}$ movimento lento (o terceiro movimento, caso o scherzo ou minueto o preceda) tem uma grande diversidade de possibilidades: forma tripartida complexa, sonata sem desenvolvimento, ${ }^{16}$ sonata com episódio no lugar do desenvolvimento, variação, sonata, forma tripartida simples, forma bipartida simples ou rondó. Em geral, movimentos lentos são feitos em tonalidades outras que a principal e, tardiamente, observamos tonalidades mais longínquas (STOÏANOVA, 2000, p.177-181).

É possível observar que o Quarteto de Debussy possui uma proximidade maior com os padrões mencionados por Stoïanova do que com os propostos por Webster: seu primeiro movimento é construído nos moldes da forma sonata (PARKS, 1989, p.217), o segundo movimento é um scherzo, formado por um minueto com dois trios (WHEELDON, 2005, p. 655), e seu terceiro movimento, lento, de fato é composto com armaduras de clave em ré bemol maior e dó sustenido menor, distante da presente nos dois primeiros movimentos ${ }^{17}$. Além disso, seus quatro movimentos seguem o padrão "rápido-moderado-lento-rápido" descrito por Stoïanova e as relações temáticas à distância são, de fato, recorrentes em sua obra em diferentes níveis. A armadura de clave no começo e no fim do scherzo também é a mesma presente no primeiro e no quarto movimentos, o que nos permite chamá-la de principal.

A utilização de modelos formais estritos como os descritos não é de forma alguma recorrente em obras deste período de Debussy. Edward Lockspeiser, referindo-

15 A autora defende que, antes de Beethoven, o ciclo em quatro movimentos era recorrente na música orquestral e de câmara, e ele se impõe como forma universal do ciclo da sonata e da sinfonia depois de Beethoven.

16 Cedric Thorpe Davie (1966, p.87) fala que "a forma sonata abreviada [abridged sonata form], ou forma sonata sem desenvolvimento, é uma estratégia conveniente para movimentos líricos onde o contraste de tonalidade entre temas principais é mais uma questão de resolução para o ouvido do que de oposição dramática."

17 Seria impreciso, dado o período de composição do Quarteto de Debussy, utilizar o termo tonalidade, como faz Stoïanova para obras de períodos anteriores. 
se às composições do início da década de 1890 de Debussy, afirma que a composição do Quarteto "representa uma renúncia temporária à literalidade e às alegorias pictóricas, e a adoção de um formato tradicional teria um retorno entusiástico apenas no fim de sua carreira" (LOCKSPEISER, 1936, p.151).

\section{A forma cíclica segundo Charles Rosen}

Charles Rosen possui uma compreensão bastante diferente da de Ivanka Stoïanova sobre o conceito de forma cíclica, o que pode ser explicado, ao menos em parte, pela ênfase no período romântico presente nos trechos dos livros nos quais a forma cíclica é citada. Tal conceito é mencionado em seus livros Sonata Forms (1988) e A geração romântica (2000), e podemos inclusive observar uma sensível mudança conceitual entre estes dois livros, que são separados por um período de dez anos.

Em Sonata Forms, o autor defende que a forma cíclica se tornou popular na geração de compositores de 1825 a 1850 como uma das tentativas de abrir a forma sonata, que era "uma estrutura fechada e ordenada", enquanto estes compositores "buscavam o efeito da improvisação":

A forma cíclica era especialmente adequada aos estilos do século XIX, uma vez que colocava a ênfase principal em relações temáticas, que predominavam cada vez mais sobre estruturas harmônicas. Relações temáticas entre movimentos diferentes de uma sonata podem ser de dois tipos: implícitas e explícitas. Citações explícitas são pouco frequentes antes de Beethoven e são raras em suas obras. A forma implícita é frequente em Beethoven, no qual, com frequência, os temas de diversos ou mesmo de todos os movimentos são claras versões do mesmo material. [...] A inovação romântica aqui (levada adiante por Tchaikovsky, Franck e outros) era integrar a citação explícita do primeiro movimento como parte de um movimento posterior, combinando técnicas implícitas e explícitas. (ROSEN, 1988, p.393-394)

Rosen defende que a forma sonata, codificada em 1840, não era mais um desenvolvimento livre de princípios estilísticos, mas uma tentativa de atingir grandeza pela imitação de modelos clássicos. Daí a relevância, nesse contexto, da forma cíclica, menos rígida formalmente que a forma sonata tradicional. Já em A geração romântica, esta falta de rigidez da forma cíclica - "um termo tão ambíguo quanto vago", segundo ele - parece ser um aspecto de relevância ainda maior do que em seu livro anterior: 
Neste sentido, a forma cíclica não é propriamente uma forma, mas a perturbação de uma forma estabelecida. Um retorno não será cíclico se requerido pela tradição em suma, se for esperado; um retorno cíclico tem de ser uma surpresa. [...] Foi, justamente, esse deslocamento de uma forma aceita que teve um tal apelo para o compositor romântico: permitiu que ele utilizasse uma forma tradicional de um modo mais pessoal. Em uma forma cíclica, o retorno pode ser justificável segundo os requisitos formais tradicionais, mas deve sê-lo, no entanto, pelo contexto e material musicais: não deve ter a aparência de algo retórico e, sim, orgânico. (ROSEN, 1988, p.141, tradução: Eduardo Seincman)

Rosen defende que "o duplo aspecto - a ruptura de uma forma padrão, necessária, mais por razões de sensibilidade e desenvolvimento interno do que pela tradição - era afim à estética do fragmento" (ROSEN, 1988, p.142), o que reforçava o interesse dos compositores desta geração por tal forma. As relações temáticas à distância, citadas por Rosen, também possuem particularidades nas mãos de Debussy, como observaremos adiante.

\section{Marianne Wheeldon e a forma cíclica em Debussy e César Franck}

Mesmo sendo possível afirmar que existem influências da forma cíclica tal como era utilizada no período clássico na elaboração do Quarteto, como foi observado anteriormente, é preciso reconhecer que a maior influência formal de Debussy nesta peça e em outras desse período é o compositor César Franck. Segundo Jean e Brigitte Massin, o compositor belga foi um dos principais responsáveis pela solidificação do conceito de forma cíclica. Massin traz outra interessante definição deste conceito:

[Franck] foi um dos primeiros, pelo menos na França, a usar e a preconizar a "forma cíclica", que é justamente o contrário de um princípio: uma célula melódica - de que o Leitmotiv wagneriano é um caso particular - que se expande e se transforma livremente no decorrer da obra, sem maiores cuidados com as regras formais do desenvolvimento clássico. (MASSIN, 1997, p.809, tradução: R. Viana, Sussekind, R. Costa)

Frank também tem importância por ter resgatado a música de câmara no meio musical francês do final do século $\mathrm{XIX}^{18}$. O compositor havia estreado seu Quarteto de

18 “O caso dos gêneros musicais ressucitados por César Franck é a melhor ilustração de sua contribuição. Para começar, foi graças a ele que a música de câmara deixou de ser, no século XIX, uma especialidade exclusivamente germânica. Se examinarmos o catálogo das obras dos compositores franceses desde o 
cordas em 1890, em concerto realizado pela Societé National presenciado por Debussy, e, segundo James Briscoe, "o jovem Debussy frequentemente recorria a Franck para modelos de estrutura em músicas instrumentais" (WHEELDON, 2005, p.645). No Quarteto de Debussy, esta influência mostra-se bastante clara na maneira como o compositor utiliza os procedimentos cíclicos:

Com todo o potencial de variação da forma cíclica, o Quarteto [de Debussy] liga seus movimentos de forma similar à [do Quarteto] de Franck: em ambos, a primeira uterância é o tema cíclico; este tema ocorre proeminentemente no segundo movimento (com diferentes aspectos), o movimento lento não faz nenhuma referência óbvia ao tema cíclico e o último movimento lembra temas dos movimentos anteriores em uma introdução antes de embarcar no finale (WHEELDON, 2005, p.647).

Para Wheeldon, uma das principais renovações realizada por Debussy nesta peça é o fato de ela possuir elementos texturais que atuam de forma cíclica, em vez de esta função ser delegada apenas a elementos temáticos, como faziam os compositores da geração de Franck. Tal característica é observada na introdução do finale do Quarteto, que é dividia em duas seções: a primeira, que vai dos cc.1-14, é "uma extensão do lento movimento anterior em timbre, clima e armadura de clave no último movimento". Já a segunda seção (cc.15-30), devido à sua métrica composta, tempo e textura, “imediatamente traz em mente o scherzo (segundo movimento), enquanto a repetição insistente de uma única ideia - aqui, terças cromáticas descendentes - lembra o persistente ostinato do tema cíclico daquele movimento" (WHEELDON, 2005, p. 648). Desta forma, as relações entre o quarto, o terceiro e o segundo movimentos deixam de depender exclusivamente de elementos temáticos:

\begin{abstract}
Ao estabelecer texturas tão distintas, Debussy cria uma identidade tímbrica única e reconhecível para cada um dos movimentos centrais, identidade que ele é capaz de extrair da mesma maneira como ele a extrai do tema cíclico. Ao fazer isto, ele eleva o papel do timbre em seu quarteto, habitualmente resignado a uma posição secundária ou um papel de suporte em uma composição. Para Debussy, o timbre dos movimentos centrais não é meramente decorativo, mas torna-se um elemento reconhecível de sua forma. Desta maneira, ele cria uma "lembrança tímbrica" dos dois movimentos precedentes insinuando - e essencialmente deixando de lado - as lembranças temáticas mais literais que iniciam o último movimento do quarteto de Franck. (WHEELDON, 2005, p.649)
\end{abstract}

início do século, inclusive Hector Berlioz, verificaremos que a sonata, o trio e o quarteto estão praticamente ausentes" (MASSIN, 1997. p.808, tradução: R. Viana, Sussekind, R. Costa). 
A figura a seguir apresenta os elementos cíclicos dos quartetos de Debussy e Franck:

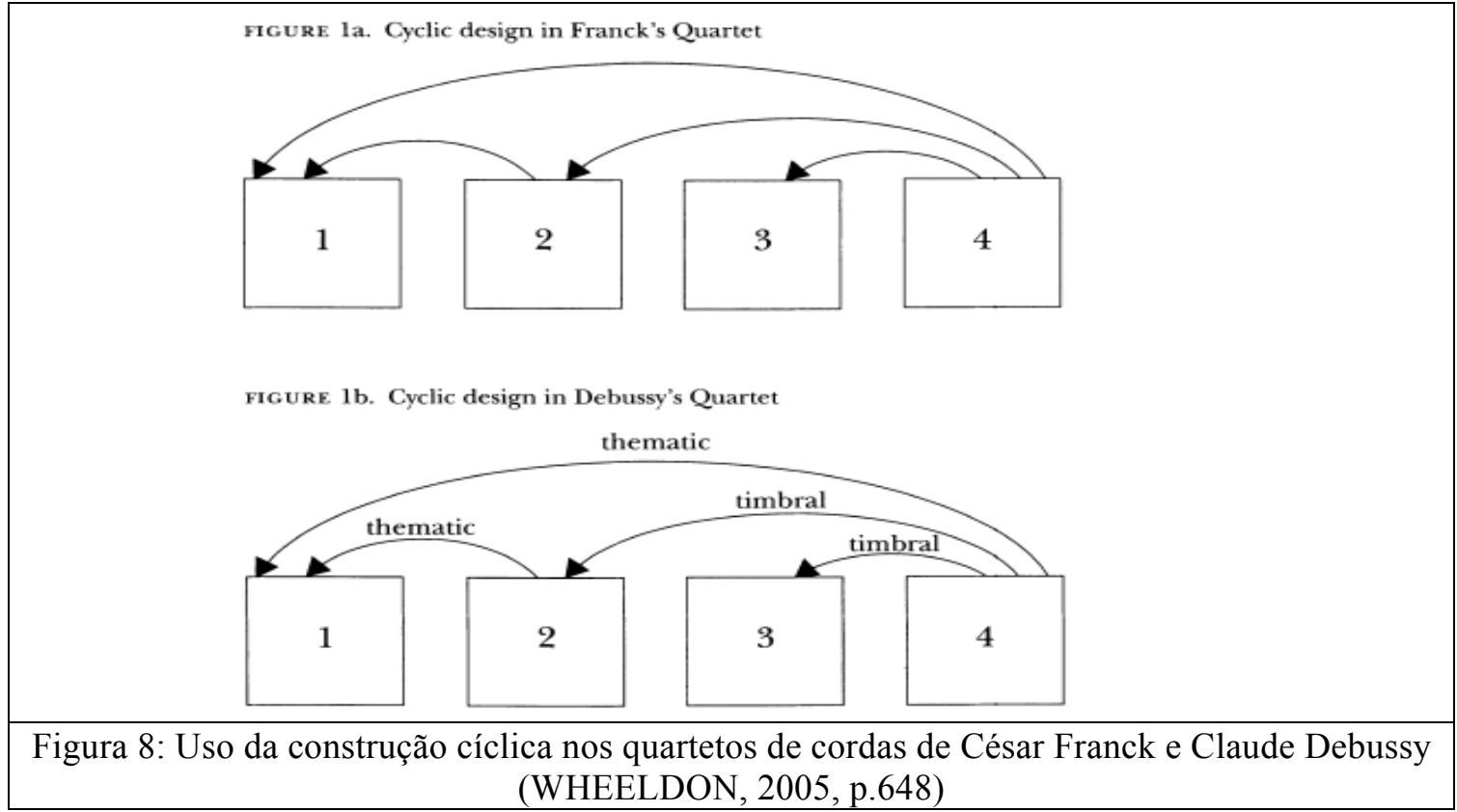

Esta forte relação entre o Quarteto de Debussy e César Franck tem suas motivações indagadas por Marianne Wheeldon. Ainda que o Debussy admirasse de fato a obra de Franck e tivesse assistido às aulas de órgão deste no conservatório de Paris, uma possível interpretação sobre a relação entre os dois é que Debussy se aproxima do compositor belga com outros interesses, particularmente o de ver suas obras executadas em programas da Société Nationale de Musique:

Neste período de sua carreira, Debussy tinha poucas obras grandes compostas, e uma estreia de seu novo quarteto de cordas na Société Nationale - lar da música de câmara francesa séria - pode ter sido um passo calculado por ele para fortalecer sua reputação dentro da Société. Além disso, Debussy estava presente na estreia do Quarteto de cordas de Franck (no dia 19 de abril de 1890), e por isso deve ter testemunhado sua recepção triunfante, com Franck sendo chamado duas vezes para agradecer aos aplausos do público. Desejoso por uma estreia bem-sucedida, Debussy responde três anos depois com o seu próprio Quarteto. (WHEELDON, 2005, p. 647)

Independentemente das motivações de Debussy - e lembrando que as duas hipóteses mencionadas acima não são necessariamente autoexcludentes - fica claro que a utilização da forma cíclica em seu Quarteto se encontra diretamente associada ao compositor César Franck. 
Outro elemento identificado como característico da forma cíclica e renovado por Debussy é o que Ivanka Stoïanova chama "plano tonal unificante", ou seja, uma coerência entre as tonalidades dos diferentes movimentos da peça. No Quarteto em sol menor, encontramos entre os quatro movimentos uma recorrência de armaduras de clave que sugerem as tonalidades de sol menor, sol maior, ré bemol menor e ré bemol maior. Se sob um plano tonal é difícil afirmar que exista uma unidade nesta série de acordes, Annie Yih identifica outros elementos que colaboram para uma sensação de unidade: ao sobrepormos as tríades presentes nestes quatro acordes, encontramos as classes de alturas sol, láb, sib, si, réb, ré, mi, fá, que formam o conjunto octatônico 8-28, por ela considerado de grande importância dentro desta peça. Desta forma, o plano formal em larga escala continua tendo o papel de articulador de unidade, porém, não por meio do tonalismo e sim por outro conjunto referencial relevante para esta composição (YIH, 2000, p.225).

Os exemplos expostos apresentaram diferentes compreensões do que são processos cíclicos em uma composição musical. Buscou-se demonstrar de que maneira tal conceito foi empregado desde o Classicismo até o final do Romantismo, traçando um recorte não apenas cronológico, mas que também partisse de uma abordagem mais genérica e ampla para chegar a uma aproximação específica do contexto aqui pesquisado. Esses conceitos serão de grande importância, pois um dos principais objetos desta pesquisa é o uso de diferentes tipos de repetição dentro do Quarteto de Debussy.

Neste contexto, a forma cíclica como definida por Wheeldon remete a uma das maneiras mais distantes, temporalmente falando, de encontrarmos a repetição (um motivo do primeiro movimento reaparecendo no último movimento da peça). Já os conceitos de Webster remetem a uma repetição por vezes imediata, e sempre de um objeto menor do que um tema (um motivo, por exemplo). Devido à proximidade com o tema aqui pesquisado, utilizaremos o termo "forma cíclica" da maneira designada por Wheeldon, utilizando o termo "desenvolvimento motívico" para processos semelhantes aos apontados por Webster, evitando desta forma ambiguidades desnecessárias e que o conceito se torne excessivamente amplo.

Observaremos a seguir elementos que atuam em um plano formal menor, em média ou pequena escala e não restritos a materiais temáticos ou motívicos, para em seguida compreender de que maneira todos estes conceitos podem se relacionar. 


\section{Forma morfológica $x$ forma cinética}

O conceito de forma cíclica é mencionado apenas de forma marginal em Parks, assim como o são outros conceitos tradicionais como a forma sonata. Tal fato se dá porque, para o autor, a "análise formal geralmente consiste em identificar esquemas de acordo com uma taxonomia desenvolvida para a música tonal e pré-tonal, que é operativa apenas de forma marginal em Debussy" (PARKS, 1989, p.172). Ou seja, tais conceitos operam de forma limitada neste compositor, fazendo com que análises de suas peças que forem baseadas exclusivamente nestes pontos sejam necessariamente incompletas ${ }^{19}$.

Para sanar esta questão, Parks estabelece a distinção entre dois aspectos formais dicótomos essenciais em sua compreensão analítica: a forma morfológica e a forma cinética. A forma morfológica traz uma concepção espacial de forma como uma disposição fixa e estática de elementos musicais (PARKS, 1989, p.234). Ela concebe a distribuição de eventos no tempo em termos de metáforas espaciais: balanceado contra desbalanceados, regularidade contra irregularidade, simetria contra assimetria, contraste versus retorno. É nela que o autor enquadra alguns conceitos tradicionais formais, como a forma cíclica:

Em Debussy, a forma morfológica é dividida em duas categorias: aquela que emprega esquemas cíclicos e simétricos tradicionais em seu mais amplo nível estrutural e formas-período neoclássicos em seu menor nível estrutural; e outros paradigmas que transformam, a partir de formas novas, as características essenciais dos tipos de formas tradicionais. A primeira categoria predomina em seus trabalhos iniciais, a segunda emerge posteriormente e é típica de seu estilo maduro, mas ambas são encontradas em todos os períodos de suas obras ${ }^{20}$. (PARKS, 1989, p.203)

A partir destes conceitos, Parks apresenta um gráfico com o tamanho das diferentes frases, períodos e seções do primeiro movimento do Quarteto de cordas de Debussy. Aqui é possível observar, de forma clara, o que Parks denomina "controle arquitetônico do compositor" (Figura 9).

19 Uma discussão mais aprofundada sobre esta questão pode ser vista no primeiro capítulo desta dissertação.

20 A dualidade entre obras do início de sua carreira, com características mais tradicionais e neoclássicas, e obras de maturidade, que utilizam de maneira mais livre tais características, será observada com mais profundidade adiante. 
Em relação à estrutura de frases e grupos de frases, observamos na figura uma "quase regularidade" presente ao longo do movimento, com uma grande incidência de frases de tamanho próximo, porém não idêntico, com apenas um ou dois compassos de diferença (das 14 grandes frases, nove possuem entre 11 e 14 compassos, duas frases possuem oito ou nove compassos, duas frases possuem 18 ou 17 compassos e uma frase possui 22 compassos). O resultado deste procedimento, segundo Parks (1989, p.216), é "uma superfície musical predominantemente regular, na qual frases de quatro compassos são a norma, mas se tornam flexíveis e imprevisíveis pelo uso liberal de extensões, truncamentos e elisões". 


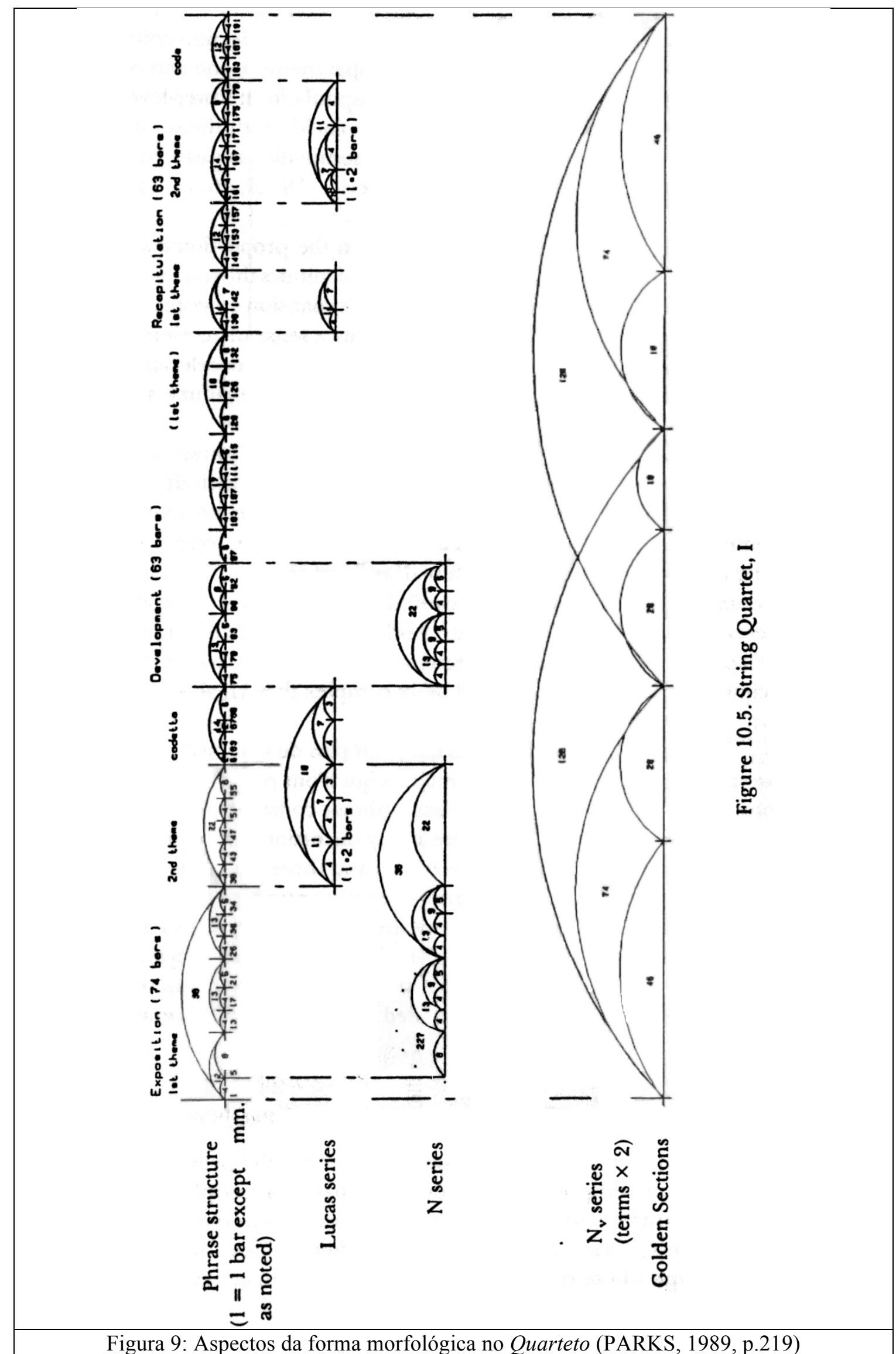

Figura 9: Aspectos da forma morfológica no Quarteto (PARKS, 1989, p.219) 
A presença de elementos simétricos e a utilização de estruturas de frase com a proporção áurea também pode ser observada na Figura 9, e observaremos no próximo item a presença de simetrias no contexto das extensões, reiterações e repetições mencionadas por Parks. O gráfico apresentado também explicita o fato de este movimento ser composto nos moldes da forma sonata, com exposição, desenvolvimento e recapitulação: é interessante notar que o Quarteto de cordas é a última peça em que Debussy se submete de forma tão flagrante a princípios formais convencionais ${ }^{21}$ (PARKS, 1989, p.285).

Já a forma cinética de Parks surge a partir da organização de descontinuidades e relaciona-se com a sensação de movimento, um aspecto importante da experiência musical em Debussy (PARKS, 1989, p.233). Na forma cinética, as mudanças - em diferentes parâmetros - são as responsáveis por proporcionar continuidade à música (enquanto na forma morfológica é a estabilidade que provém a continuidade): consistentes padrões de mudanças dentro da forma cinética são responsáveis pela coerência de um aspecto em particular. Alguns exemplos mencionados por Parks são: uma série de entradas separadas por durações cada vez mais curtas; registros extremos em constante expansão ao longo de um campo de registro flutuante; unidades formais sempre contrastantes (unidades formais estas que pertencem ao campo da forma morfológica).

Nesta pesquisa, entendemos que os dois processos descritos não são necessariamente antagônicos: é possível existirem processos cinéticos ocorrendo com fronteiras similares às de processos morfológicos. $\mathrm{O}$ que determina a classificação de um evento dentro de uma ou outra categoria é a relação que um determinado evento cria com outros acontecimentos que o circundam, a partir de continuidades (forma morfológica) ou de padrões consistentes de rupturas (forma cinética). Estas relações entre diferentes acontecimentos são capazes de formar diferentes tipos de processos cinéticos, conforme observaremos adiante.

Antes de observarmos exemplos de processos cinéticos existentes no Quarteto, é necessário elucidarmos algumas questões que se mostrarão de grande importância não apenas para estes processos específicos, mas também para toda a pesquisa. Trata-se de

21 Pode-se afirmar que princípios formais convencionais semelhantes aos do Quarteto são observados em peças do fim de sua carreira como as três "sonatas de câmara". Porém, nestas sonatas, tais princípios adquirem características particulares que as distinguem da forma como são empregadas aqui. Sobre a relação entre o Quarteto e as "sonatas de câmara", ver WHEELDON (2005). Sobre as três sonatas de câmara, ver ALLEN (1983), SOMER (2005) e ABRAMOVAY (2011). 
compreender de que maneira são utilizados elementos repetidos na música de Debussy, elementos que estão diretamente ligados à forma cinética de Parks, como observaremos adiante.

\section{Sobre a repetição na música}

De modo geral, é possível encontrar diferentes tipos de repetição dentro da música. Quando observamos, por exemplo, que existe uma predileção por frases de quatro compassos que se tornam flexíveis (FERRAZ, 1998, p.50) ao longo do primeiro movimento do Quarteto, existe uma espécie de repetição, presente no padrão do tamanho das frases em questão (trata-se neste caso de um tipo de repetição menos evidente). Da mesma forma, ao apresentarmos distorções de um mesmo material temático (Figura 17), existe algum nível de repetição de um mesmo material em questão, mesmo que não seja uma repetição idêntica. Neste sentido, é interessante destacarmos o trecho a seguir do livro Música e repetição, de Silvio Ferraz, que elucida algumas questões sobre esses aspectos.

A constatação da repetição se dá a partir da identificação de elementos semelhantes e da criação de diversos graus de analogia entre o objeto que acaba de ser repetido e aquele que sobrevive enquanto memória e lembrança. Desse jogo de equiparações, o grau mais complexo parece ser o da analogia, é pela analogia que relacionamos elementos nem sempre facilmente relacionáveis por suas características gerais. São análogos desde objetos-sonoros de aspectos físicoacústico similares, até objetos-musicais que se remetem a um objeto original transmutado por retrogradação, ampliação, inversão, permutação - analogias mais e mais complexas que não estão mais restritas à escuta. Nesse plano de analogia é que se distinguem então níveis de repetição e de variação com relação a um objeto dado.

Tanto a repetição que identifica pelas semelhanças superficiais quanto aquela que envolve um certo grau de diferenciação podem ser vistas como repetição e garantem para grande parte dos compositores - e, por consequência, dos ouvintes que uma música se mantenha a mesma do começo ao fim. (FERRAZ, 1998, p.34)

Fica evidente, então, não apenas de que maneira a repetição se encontra presente no exemplo da Figura 17, onde diferentes tipos de analogias podem ser observados, mas também sua finalidade, que é fortalecer a sensação de coerência dentro da composição musical. Uma importante distinção apontada por Ferraz é a diferença entre reiteração e reapresentação na música: 
No que diz respeito às notas, frases e ritmos, distinguimos as repetições imediatas - as reiterações - e as repetições a distância - as reapresentações. Exemplos desses dois modos de repetição (proximal e a distância) são, por exemplo, as reiterações imediatas - variadas ou não - de motivos na música de culturas tradicionais e as repetições a distância notadas nas reapresentações de elementos temáticos na música tonal. (FERRAZ, 1998, p.34)

Observaremos adiante que não apenas encontramos os dois tipos de repetição em larga escala no Quarteto, mas os exemplos citados por Ferraz enquadram-se com uma precisão notável nesta peça. Já foi destacado o uso de elementos temáticos da música tonal em reapresentações (com o emprego da forma cíclica), e alguns autores destacam a influência do gamelão da música javanesa como enraizado na composição do Quarteto (LOCKSPEISER, 1936, p.40), possivelmente associado ao uso de reiterações.

\section{Sylveline Bourion e a repetição em Debussy}

Investigaremos nas próximas páginas de que maneiras diferentes procedimentos composicionais relacionados à repetição dentro da música se manifestam no Quarteto de Debussy. Tais características foram estudadas com profundidade no livro Le Style de Claude Debussy, de Sylveline Bourion (2011). Observaremos que estes elementos se relacionam diretamente com o conceito de forma cinética de Richard Parks e que ambos são determinantes para a sensação de movimento ou direcionalidade de determinados trechos.

É preciso explicar primeiramente uma questão referente à nomenclatura utilizada nesta pesquisa. Utiliza-se o termo "reiteração" como algo análogo ao que Bourion se refere como "duplicação". Optou-se por fazer essa alteração por duas razões: a primeira é que existe em português um trabalho que trata extensivamente do assunto e possui nomenclatura própria (FERRAZ, 1998), o que faz com que adaptação do francês não seja necessária. A segunda é que o termo "duplicação" já carrega significados em outras áreas musicais, principalmente no âmbito da orquestração, o que faz com que sua utilização possa trazer mais ambiguidades. Dessa forma, em trechos em que a autora se referir à "duplicação", realizaremos a alteração para o termo "reiteração".

Existe, ainda no fim do século XIX, uma mudança de paradigma no uso de reiterações e reapresentações por parte de Debussy, e o Quarteto, afirma a autora, 
possui um papel relevante neste aspecto. Tal mudança encontra-se na "inversão de papéis entre o microscópico (o local) e o macroscópico (o estrutural)" (BOURION, 2011, p.257):

No início [de sua carreira, até o ano de 1882], havia de forma bastante forte nas obras de Debussy a ideia de retorno de alguma coisa conhecida, já ouvida, como forma de marcar a estrutura de sua peça e, sem dúvida, de torná-la perceptível para o ouvinte. [...] Isto começou pelo todo estrutural, ou seja, uma repetição - variada, de uma reprise a outra, em um nível mais ou menos importante - de toda a primeira seção para formar as seções subsequentes. [...] Mas a ideia de uma repetição curta, ou seja, que esta seja da ordem do motivo (de frase, a rigor, mas certamente não de seção), fez o seu caminho na metodologia produtiva do compositor, com o abandono progressivo dos retornos de seções [completas]. (BOURION, 2011, p.257)

Esta inversão de papéis existente entre o macro e o microscópico se dá, segundo Bourion, da seguinte forma: em obras da juventude de Debussy, observamos diversos esquemas formais herdados do Classicismo que favorecem uma "ordem microscópica do motivo, da frase - linear, não recorrente, e uma ordem macroscópica ligada à recursividade e à recorrência" (grifos de Bourion). Ou seja, as frases são constituídas de elementos que não se repetem, e o nível de repetição, necessário para a coesão da obra, é encontrado no retorno ou na reprise de uma grande seção (ou seja, por meio de reapresentações). Na sequência dos acontecimentos, estes dois papéis, de variedade e de retorno, serão invertidos entre o macro e o microscópico: em melodias posteriores, é o microscópico que assegura a presença da recursividade na obra (por meio de reiterações), enquanto a forma global não se repete (BOURION, 2011, p. 258). Desta forma,

[...] antes ou depois de 1882, o linear e o recorrente compartilham a constituição da obra e agem em conjunto, porém em níveis hierárquicos distintos. Porém, o esquema que tende a se impor é aquele no qual o contínuo (o linear) serve de ligação ao descontínuo (o recorrente). É igualmente este esquema que encontramos nos trechos do Quarteto que examinamos: o que liga os diversos elementos constitutivos de unidade estrutural autônoma é menos o retorno, a reiteração de um elemento já apresentado, que outros parâmetros de integração não recursivos. (BOURION, 2011, p.259)

O Quarteto também possui um papel particular sob este aspecto pois, mesmo sendo ele formado, como vimos anteriormente, por esquemas formais herdados do Classicismo (o que o aproximaria da primeira categoria descrita por Bourion, de obras 
do início de sua carreira, nas quais a repetição se encontra prioritariamente no plano macro), seu padrão no uso de reiterações encontra-se mais próximo ao de obras maduras, nas quais a repetição se encontra presente no plano microscópico. Observamos que a autora, assim como Parks, menciona este deslocamento particular desta peça com relação à suas contemporâneas.

\section{Uso de reiterações no Quarteto}

Bourion (2011, p.281-283) apresenta uma análise do trecho entre os cc.17-22 do primeiro movimento do Quarteto, observando características sobre reiterações que nos permitem compreender de que maneira esta contribui para o plano formal da obra (Figura 10).
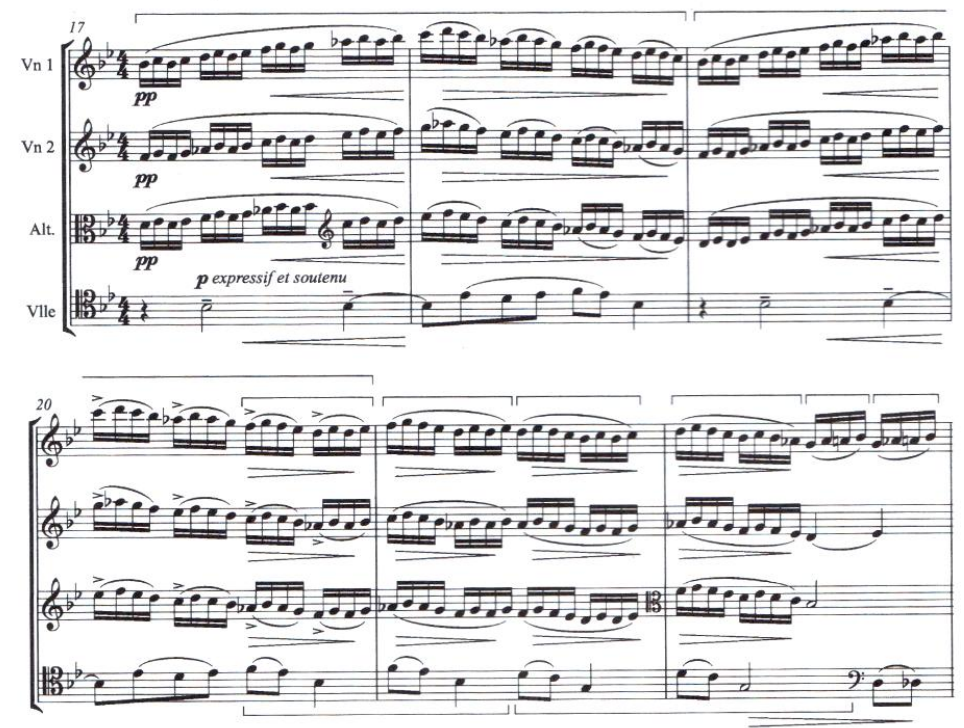

Figura 10: Cc.17-23 do primeiro movimento do Quarteto (BOURION, 2011, p.281)

Os quatro primeiros compassos são formados por unidades de dois compassos reiteradas. A partir do quinto compasso, as reiterações passam a ter dois tempos, ou seja, um quarto de seu tamanho original. No sexto compasso, o tamanho das unidades reiteradas diminui ainda mais, durando apenas um tempo, um oitavo do tamanho original. Porém, como aponta Bourion, possivelmente com o objetivo de assegurar uma regularidade ao tamanho das diminuições, podemos encontrar também um gesto com tamanho de um compasso, aparente não em uma reiteração, mas sim em uma 
transposição de gesto (cc.20-21 e 21-22). Tal fato garante que o tamanho dos gestos diminua de forma regular, sempre pela sua metade, que é a forma habitual de encontrarmos tal procedimento, segundo a autora.

Bourion defende que existem quatro parâmetros trabalhando pela direcionalidade desta passagem e por sua coerência estrutural:

- Um decrescendo estrutural que transforma unidades de dois compassos em unidades de um tempo.

- Uma progressão que vai da reiteração pura em direção a modificações cada vez mais audíveis e visíveis (ou seja, impurezas crescentes nas reiterações).

- Um movimento de registro que segue a curva decrescente da reiteração.

- Nuances de dinâmica associadas diretamente à direção do registro: subindo/crescendo, descendo/decrescendo.

Se observarmos não apenas o trecho em questão, mas também os cc.13-25, podemos chegar a algumas conclusões adicionais. Aqui, algumas afirmações da autora são reforçadas, como o grande decrescendo estrutural das reiterações, que se torna ainda mais visível a partir da figura seguinte, em que o tamanho das unidades reiteradas ou transpostas ao longo do trecho é visto proporcionalmente.

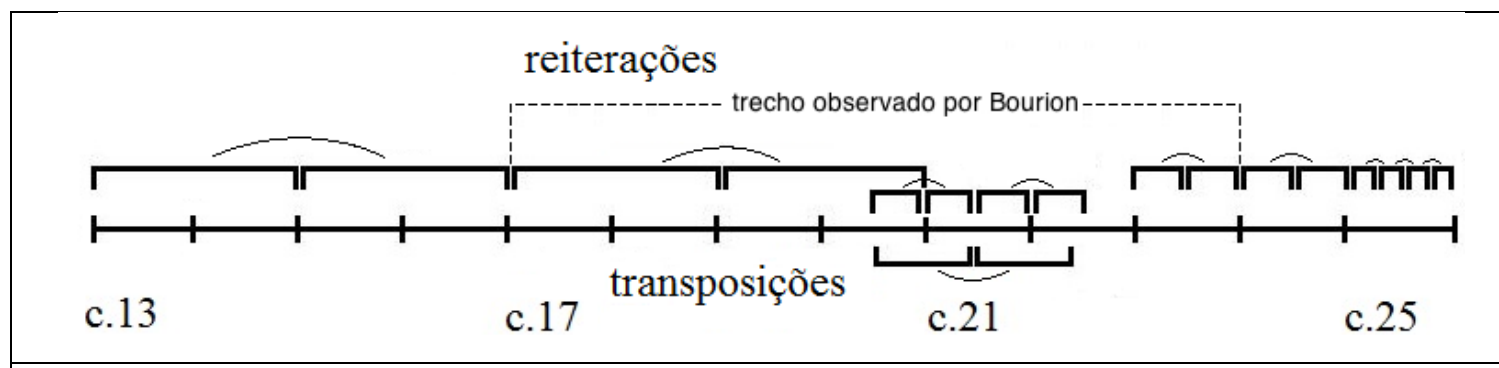

Figura 11: Representação proporcional do tamanho das unidades reiteradas entre os cc.13-25

Porém, outras ideias da autora precisam ser revistas ao analisarmos o trecho em sua totalidade. A principal é que existe uma impureza crescente e progressiva nas reiterações deste trecho, ou seja, um menor uso de reiterações. Encontramos, de fato, gestos não reiterados entre os cc.22-23. Porém, nos dois últimos compassos, cc.24-25, essas impurezas deixam de acontecer - não apenas isso, mas também podemos observar que, no cc.25, o nível de repetição se torna extremamente elevado, como mostra a figura seguinte. 


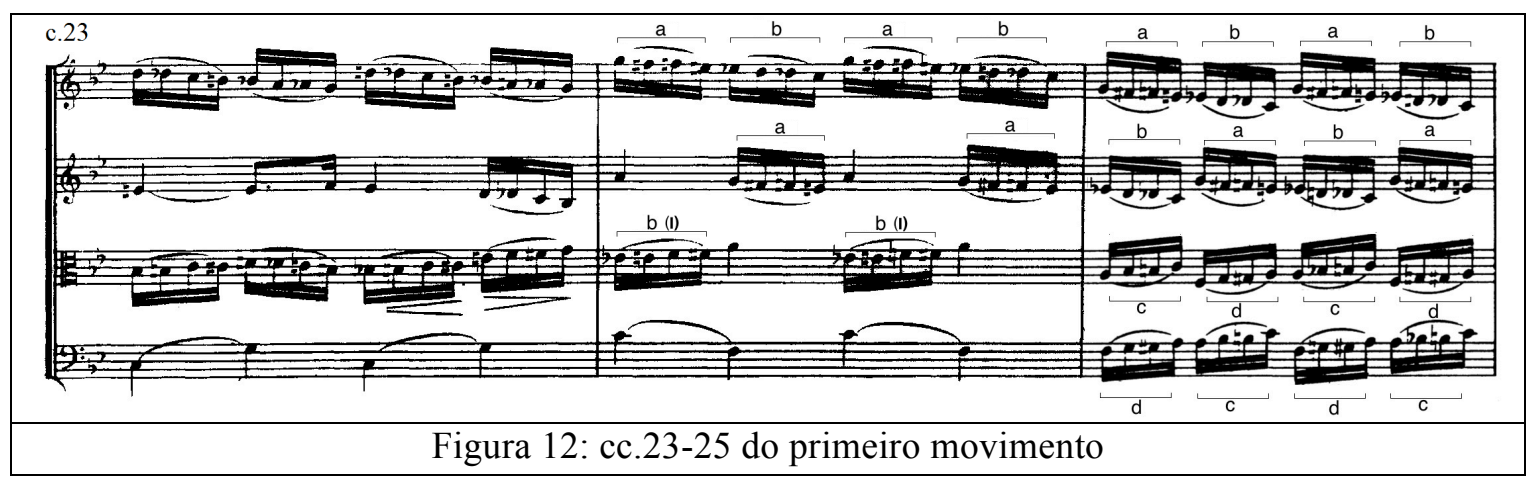

O compasso 25 traz algumas particularidades: se, em um primeiro momento, acreditamos que estamos diante de apenas uma reiteração de um gesto de dois tempos, tal fato mostra-se equivocado ao levarmos em conta possíveis trocas de vozes entre instrumentos. Levando este fato em consideração, é possível notar que cada gesto possui a duração de apenas um tempo e é repetido de forma idêntica quatro vezes, mudando o instrumento em que cada gesto ocorre por meio de uma alternância em ziguezague entre violino I e II e entre viola e violoncelo. O nível de repetição (ou de redundância de informação) torna-se ainda mais elevado se levarmos em conta que os quatro gestos observados anteriormente (a, b, c, d na Figura 6) são formados pela mesma relação intervalar transposta e/ou invertida, ou seja, são análogos. Isso faz com que, do ponto de vista das reiterações, a direcionalidade do decrescendo estrutural do trecho em sua totalidade (cc.13-25) se torne extremamente elevada, pois ela se inicia da reiteração literal de um trecho longo, complexo, com melodia e acompanhamento de dois compassos de duração sendo reiterados (cc.13-14+15-16, cc.17-18+19-20) e termina com a reiteração (aliada a inversões e transposições), também literal, de um único movimento cromático e com apenas um tempo de duração (c.25). Harmonicamente, também encontramos forte direcionalidade, pois o trecho inicia com uma melodia de características pentatônicas e acompanhamento essencialmente diatônico; progressivamente, o cromatismo é inserido em figuras de acompanhamento (figura 12), e o trecho termina com o total cromático presente em cada um dos quatro tempos do c.25 (neste sentido, a impureza, mencionada por Bourion, poderia ser associada ao aumento progressivo de utilização do cromatismo).

Tal constatação coloca em destaque a semelhança conceitual entre as implicações do uso de reiterações neste trecho (segundo Bourion) e a descrição de processos que influenciam a forma cinética (segundo Parks). Para ambos, o que importa não é necessariamente o conteúdo intervalar dos elementos, mas sim de que maneira 
esta unidade interage com seu meio, alterando acima de tudo a percepção na sensação de movimento de determinado trecho. No exemplo anterior, o processo de redução do tamanho de unidades estruturais - e, notavelmente, a regularidade com a qual ele ocorre - encaminha o ouvinte para a sensação de esgotamento, de que elementos novos (ou, ao menos, diferentes deles mesmos) serão apresentados. E é o que ocorre nos próximos compassos.

A relativa pouca importância dada por estes autores ao material intervalar deste trecho não nos impede de fazer algumas observações neste sentido; afinal, aqui também podemos encontrar algumas predileções do compositor. Existe, por exemplo, uma grande incidência de unidades de gestos melódicos com o âmbito de uma quinta justa. É o caso das melodias reiteradas entre os cc.12-22 e do baixo reiterado entre os cc.23-24. A partir do c.22, quando passam a predominar gestos reiterados com a duração de dois tempos, observamos que todas as figuras de acompanhamento também possuem âmbito de uma quinta justa. Uma vez identificada tal divisão, torna-se evidente que, mesmo no início do trecho, onde as figuras de acompanhamento eram formadas por gestos com dois compassos de duração, já existiam gestos que, se separados a cada dois tempos, apresentavam o mesmo âmbito de quinta justa presente no fim do trecho.

\section{Simetria em reiterações ${ }^{22}$}

Bourion (2011, p.26) afirma que, tratando-se da associação entre reiterações e práticas composicionais em Debussy, “o conteúdo musical de elementos estruturalmente em jogo não nos interessa tanto quanto a relação - de simetria, de identidade, de oposição, de complementaridade etc. - que os posiciona um em relação ao outro". Tal fato confere ao procedimento analítico da autora uma liberdade maior para estabelecer comparações entre estruturas musicais e outros tipos de estruturas organizacionais. Para demonstrar como Debussy faz uso de reiterações, Bourion estabelece parentescos entre os procedimentos composicionais do autor e estratégias de guerra, nas quais o posicionamento das diferentes personagens (exército inimigo,

22 Este trabalho utilizará ideias presentes em Salles (2009, p.41-47) para a compreensão do conceito de simetria. O autor realiza uma separação entre quatro tipos de simetria: bilateral, translacional, rotacional e ornamental. Observaremos com mais frequência exemplos de simetria bilateral, presentes em exposições temáticas no início do primeiro movimento e em características relativas à reiteração, como a observada a seguir. Simetrias translacionais também poderão ser observadas. 
cavalaria, soldados etc.) possui grande importância no momento do confronto. Não faz parte do objetivo da autora buscar analogias sonoras para as estratégias bélicas, como se houvesse um tipo de "sonoridade atacante", mas sim apontar semelhanças visuais e estruturais entre uma situação que exige um tipo de organização específica, no caso, uma situação de ataque ou defesa de um exército, e a maneira como se organizam as reiterações dentro da música de Debussy.

Uma das estratégias de guerra destacadas por Bourion é a "técnica do martelo e da bigorna", na qual é estabelecida uma linha de ataque situando grupos de cavalaria nas duas extremidades da linha e a infantaria em seu centro:

\begin{abstract}
A primeira fase de ataque consiste em avançar com o "martelo", ou seja, a cavalaria, em direção ao inimigo: este contorno inicial enclausura o batalhão adversário que, contido em um espaço fechado do qual ele tenta sair, se vê obrigado a ir adiante; é aí que a "bigorna" chega. As falanges de infantaria, colocadas atrás durante a primeira fase da operação, esmagam as forças do adversário e eliminam qualquer chance de fuga ou retração. A bigorna e o martelo, apertando o cerco, esgotam as tropas adversárias e dizimam o inimigo derrotado, incapaz de escapar da armadilha. (BOURION, 2011, p.242)
\end{abstract}

$\mathrm{Na}$ composição musical, Bourion encontra um paralelo entre a "técnica do martelo e da bigorna" e a ocorrência de duas reiterações de forma espelhada:

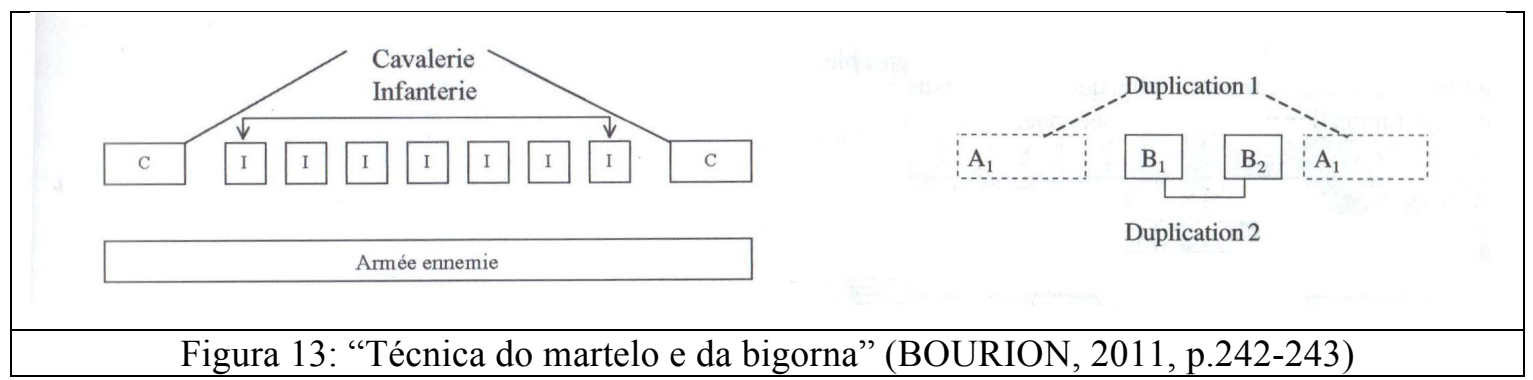

Bourion exemplifica este tipo de movimento, simétrico por ser espelhado em seu eixo vertical, no trecho entre os cc.26-31 do primeiro movimento do Quarteto. 


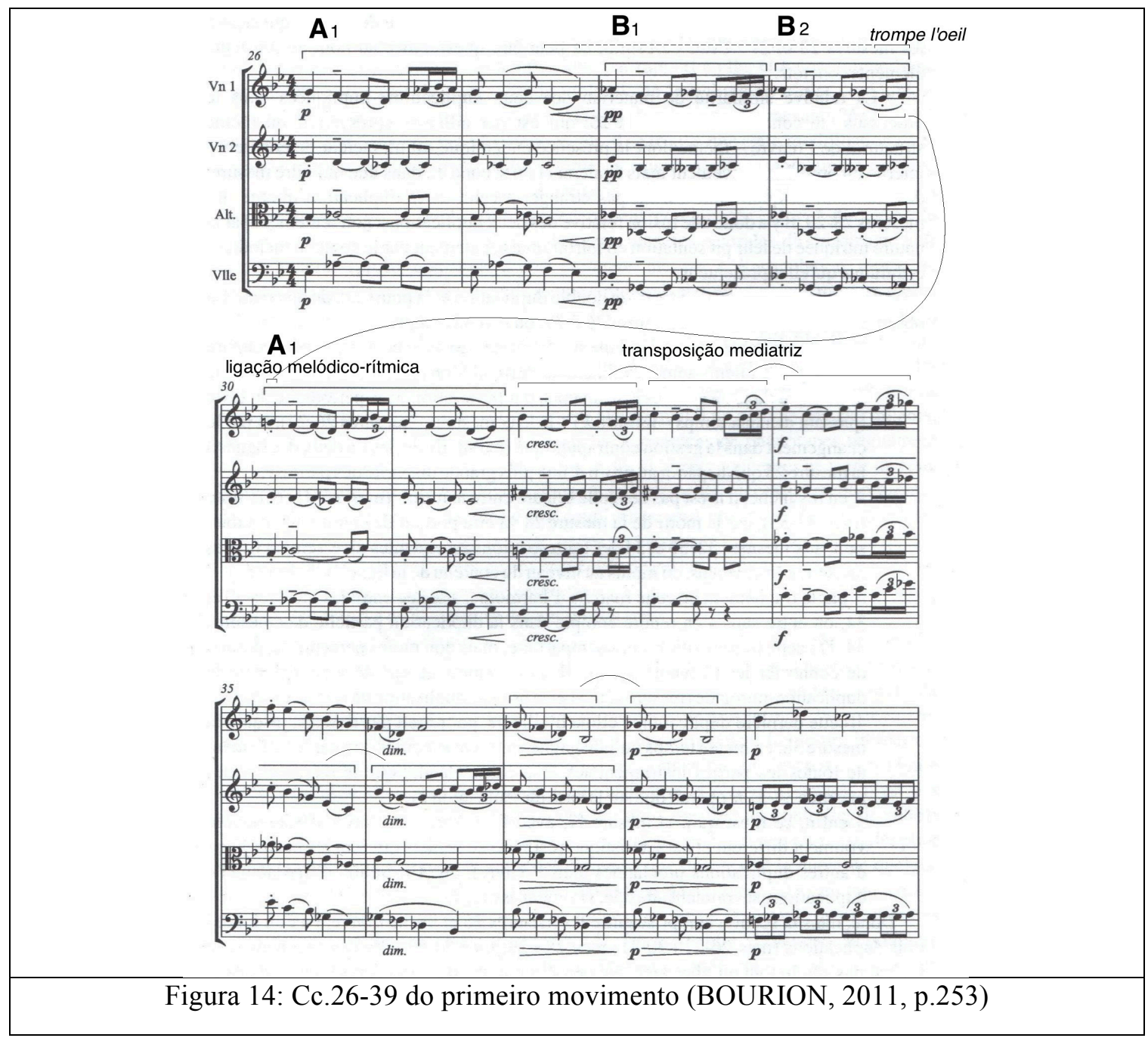

Mesmo sendo este espelhamento bastante claro, ao menos visualmente, a autora questiona sua perceptibilidade auditiva por duas principais razões: pela relativa similaridade do material das duas reiterações em questão (o que faz com que elas acabem se fundindo) e devido à ausência de corte entre esta dupla reiteração e o prosseguimento do discurso, cc.32-38, trecho onde encontramos reiterações entre cc.3435 e cc.36-37 e também entre c.37 e c.38. Aqui, alguns procedimentos ocorrem dentro das reiterações de modo a não apenas suavizar a transição entre um trecho reiterado e outro mas também a estabelecer relações de proximidade entre dois momentos diferentes (como os cc.26-32 e 32-38). A autora destaca três destes procedimentos:

- A modificação "por trompe-l'oeil", na qual pequenas modificações em uma reiteração fazem com que sua aparência se aproxime de outro trecho com o qual ele não partilha o vínculo da reiteração. Um exemplo encontra-se no último tempo do c.29, em que a ausência da tercina de semicolcheias da voz 
do violino I faz com que ele se assemelhe ao c.27, pertencente a outra reiteração.

- A transposição mediatriz, que conecta duas reiterações distintas ligando seus diferentes registros por meio de uma continuidade. É o que ocorre entre os cc.32-35, onde o registro se torna progressivamente mais agudo a cada transposição realizada.

- A ligação melódico-rítmica, que faz com que elementos estruturalmente distintos (como duas reiterações diferentes) estejam ligados de modo a suavizar a transição de um a outro. Entre o c.29 e c.30 do violino I, observamos que o movimento ascendente no final de uma reiteração se encontra em fusão perfeita com o início da próxima reiteração.

Estes processos aproximam as diferentes reiterações presentes no trecho e fazem com que ele seja entendido em sua totalidade, sendo impossível caracterizar cada reiteração como uma unidade autônoma. Tal fato é essencial para Bourion (2011, p.254), pois demonstra "de que maneira esta linguagem, a reiteração endêmica em Debussy, tão repetitiva e estruturada pela adição de estruturas elementares, pode desembocar em um discurso tão íntegro, fluido e hábil”.

Nos primeiros 12 compassos da peça, também é possível observar processos semelhantes aos descritos por Bourion no trecho analisado. Identificamos a utilização da "técnica do martelo e da bigorna" nos primeiros quatro compassos na linha do violino I (ainda que de forma imperfeita, pois a última reiteração ocorre uma oitava acima). A transposição mediatriz também ocorre no violino I entre o c.6 e o c.8. Nos primeiros 12 compassos, fica clara a progressiva diminuição de tamanho das reiterações. Mais uma vez, reiterações atuam de forma a produzir uma sensação de esgotamento. 


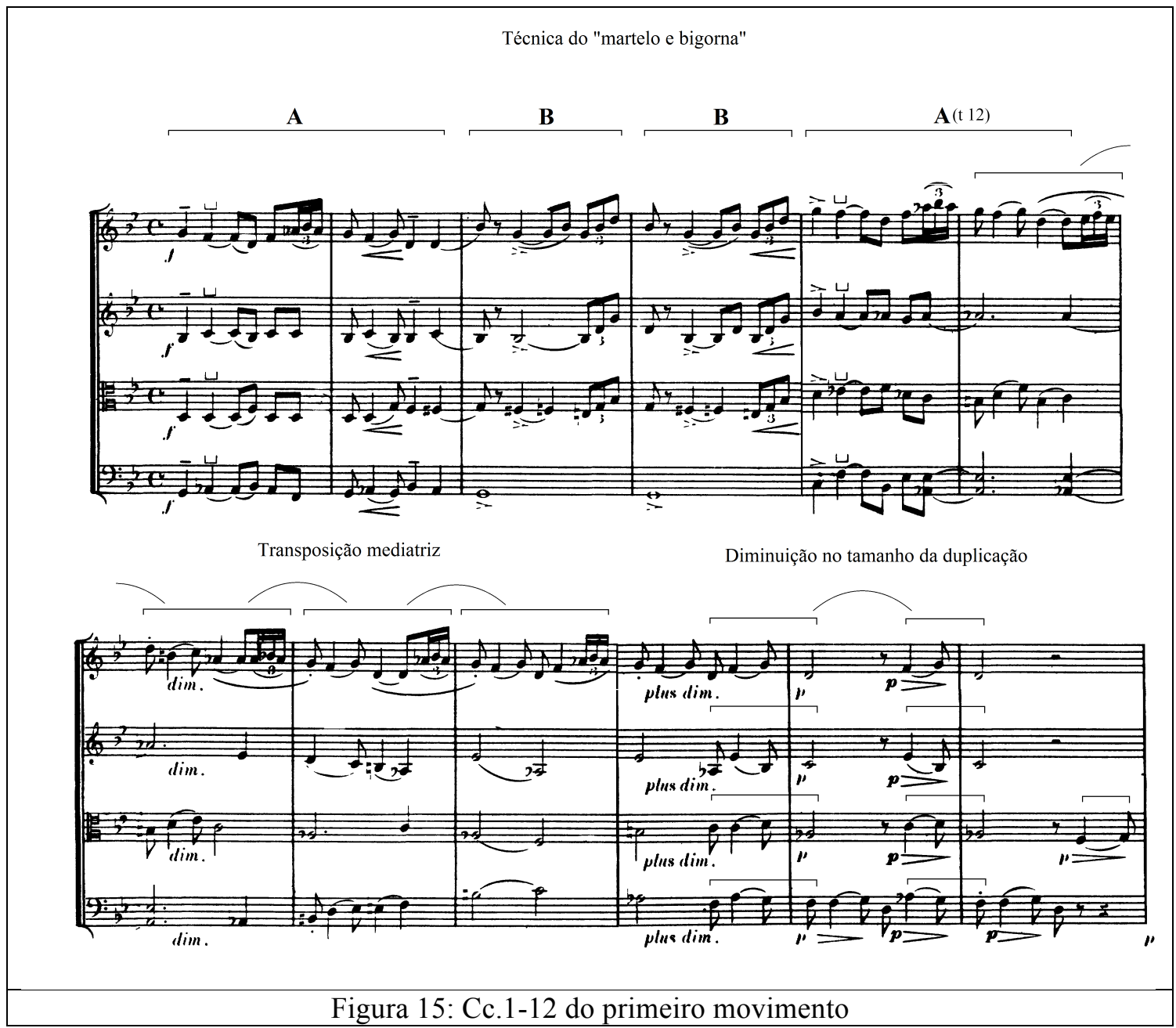

Existe também um aspecto relacionado à simetria nos primeiros dois compassos da peça que merece destaque. Em suas vozes extremas, o movimento de vozes é realizado sempre de forma inversa; se a voz superior sobe, a inferior desce. Tal característica torna-se diretamente associada ao primeiro motivo da peça, pois se encontra presente em todas as exposições do tema, mesmo quando este se encontra em contextos harmônicos radicalmente diferentes, como nos cc.75-76. Porém, a inversão no movimento das vozes extremas também pode ser vista no Quarteto separada destas exposições temáticas nos cc.163-168 e nos cc.179-182, trecho que prepara o último gesto da música, uma rápida descida pentatônica em oitava paralelas. Isso permite que se estabeleça uma relação de proximidade textural entre o final da música e seu início, o que deve ser levado em consideração pois, melódica e harmonicamente, essa proximidade é vista com mais dificuldade. 


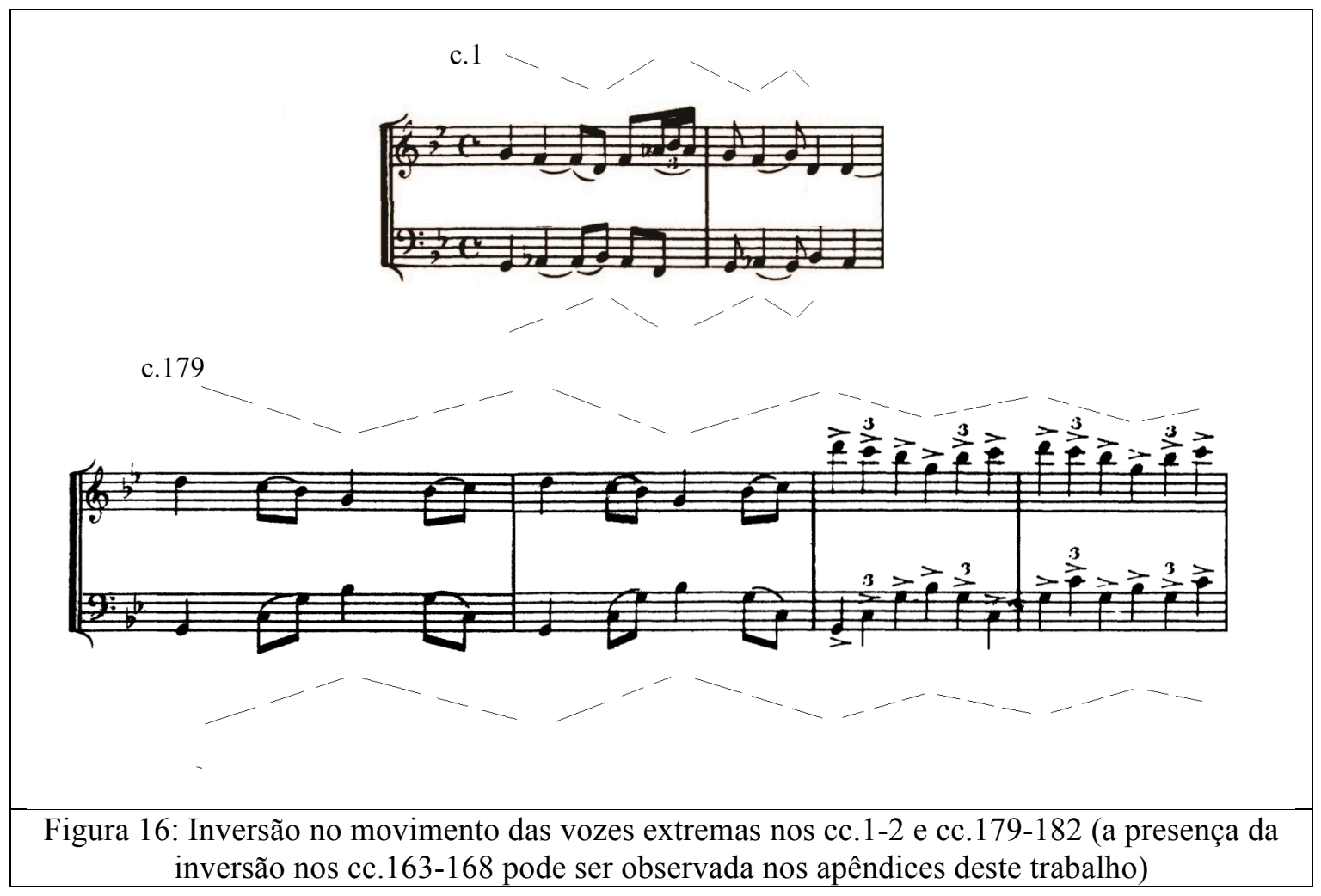

A compreensão de que uma semelhança textural pode trazer identidade entre este trecho e o tema do início da peça remete diretamente à compreensão de Marianne Wheeldon da maneira como o ciclicismo é empregado no Quarteto. Observamos que, segundo a autora, a contribuição de Debussy para este processo formal encontra-se no fato de ele utilizar o timbre como elemento que se torna cíclico entre o segundo e o terceiro movimento. Neste caso, é a textura presente no início do primeiro movimento que retorna em seu final.

O trecho entre os cc.39-60 assemelha-se aos cc.13-25 por possuírem eles elementos texturais em comum: em ambos encontramos melodias acompanhadas por velozes figuras de bordadura que (pela rápida mudança de alturas) impedem que haja uma percepção harmônica definida nos trechos. Ambos também apresentam modelos de reiteração semelhantes. Encontramos novamente entre os cc.39-60 trechos longos, de mais de um compasso reiterado: desta vez, duas frases de quatro compassos (cc.39$42+$ cc.43-46) seguidas por duas transposições "mediatrizes" (cc.51-52, cc.53-54, cc.5556), como demonstra a figura a seguir. 


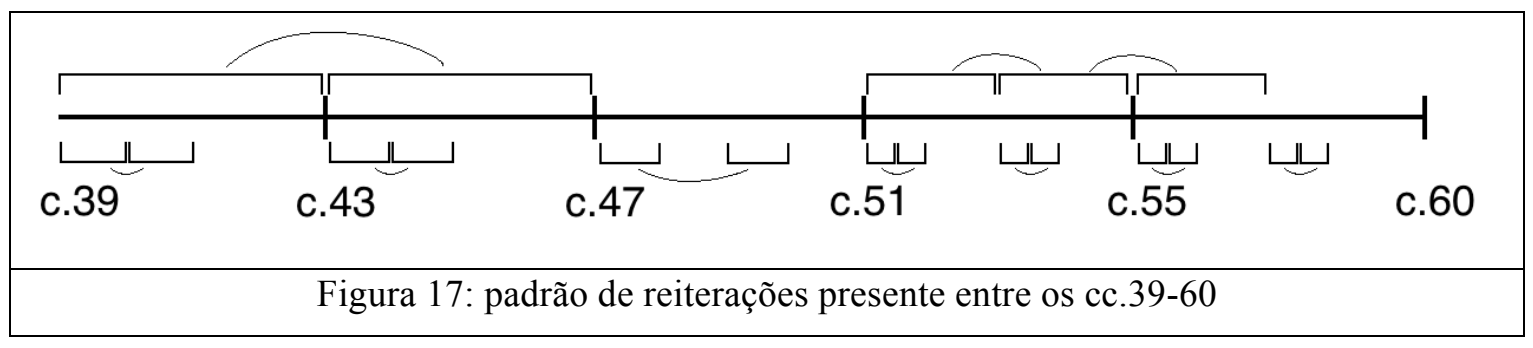

Ao longo deste capítulo foram observadas diferentes características relativas ao uso de reiterações na música de Debussy. Buscou-se demonstrar que existe um pensamento sofisticado na maneira como o compositor lida com estes elementos, fazendo com que estudá-lo seja necessário para uma boa compreensão formal da peça. Também se apresentou a semelhança conceitual entre o uso de reiterações segundo Bourion e o conceito de forma cinética de Richard Parks. A seguir observaremos de que maneira a forma cinética pode ser compreendida em um plano formal mais amplo, trazendo também características relativas ao uso de reiterações na música de Debussy que não somente as descritas por Bourion. 


\section{Propostas analíticas para o Quarteto}

O presente capítulo busca integrar os conceitos observados anteriormente em propostas analíticas originais de trechos do primeiro movimento do Quarteto em sol menor de Claude Debussy. O objetivo aqui é demonstrar de que maneira a forma cíclica e características ligadas à reiteração e à reapresentação podem relacionar-se, apresentando elementos relevantes para o processo composicional de Debussy dentro de seu Quarteto de cordas em sol menor. A comparação entre o primeiro movimento do Quarteto e o primeiro movimento da Sonata para flauta, viola e harpa, peça do final da carreira de Debussy, também é interessante para que se compreenda que tipos de mudanças ocorrem entre duas peças com importantes elementos comum, porém compostas em polos cronológicos opostos.

\section{Exposições temáticas e a forma cinética}

Para Parks, o conceito de forma cinética é um potente organizador de forças em Debussy, pois relaciona-se com elementos que, muitas vezes, estão distantes dos presentes em análises tradicionais, porém são de importância estrutural na obra deste compositor. Nas próximas páginas, serão observadas algumas características do Quarteto que podem ser relacionadas com o conceito de forma cinética com o objetivo de investigar se é possível encontrar coerência em um plano formal intermediário segundo estes critérios e, desta maneira, compreender melhor a importância que este conceito pode ter para uma análise da obra.

Um primeiro exemplo pode ser observado em relações temáticas no início do primeiro movimento. É possível observar que a primeira metade do tema inicial (que é o tema que se torna cíclico nos próximos movimentos) é de grande importância para materiais melódicos que o precedem. 


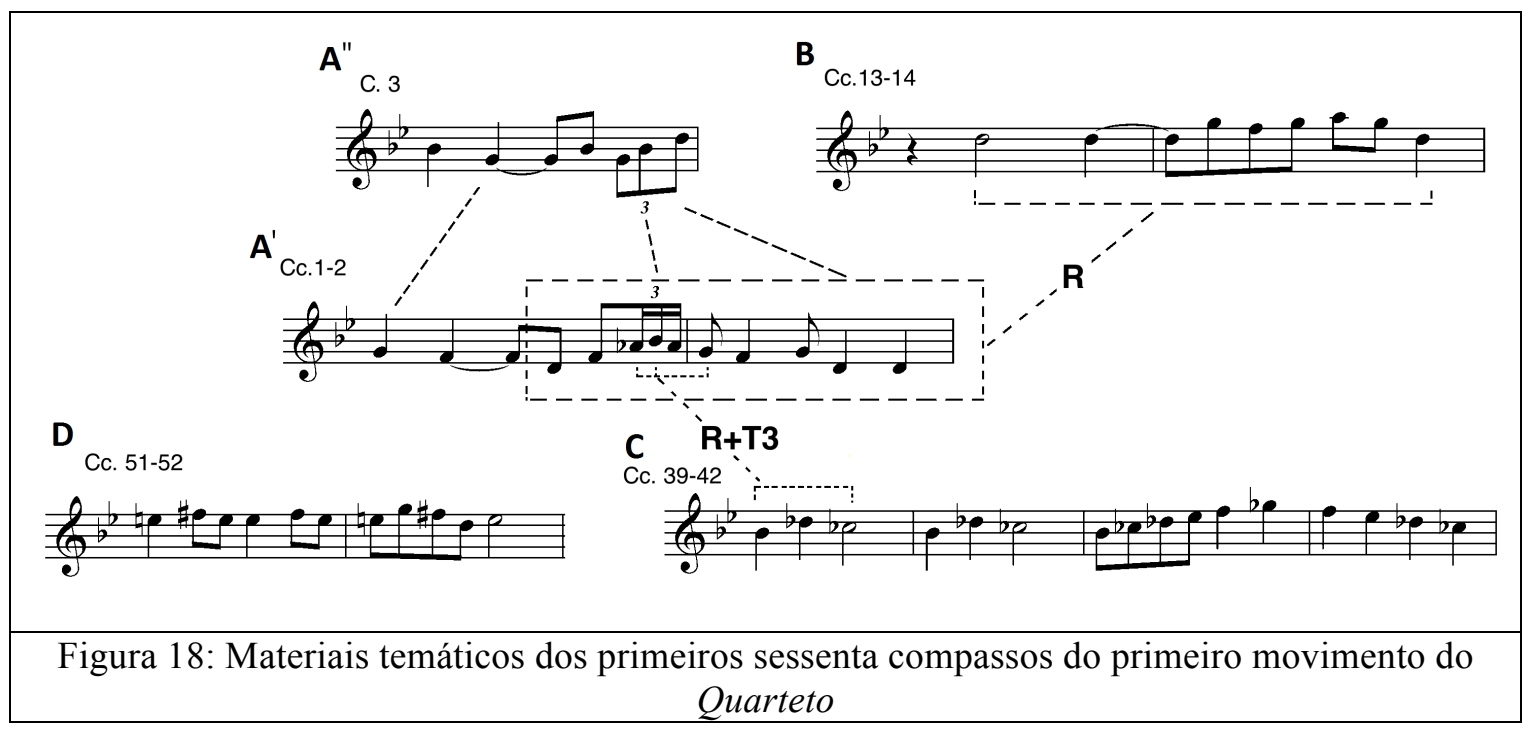

A Figura 17 apresenta os quatro materiais melódicos presentes nos primeiros sessenta compassos do primeiro movimento do Quarteto (o primeiro material melódico, A, encontra-se segmentado na figura). Alguns elementos relacionam os diferentes temas com a primeira metade de $\mathbf{A}$ (A', cc.1-2), ao centro: a segunda metade de $\mathbf{A}$ (A”, c.3) utiliza as duas notas extremas de seu contorno melódico (ré e si bemol) e a nota central (sol) do início do tema. O tema $\mathbf{B}$ (cc.13-14) é uma retrogradação quase literal de $\mathbf{A}$, apenas sem a bordadura central deste. O tema C (cc.39-42) utiliza uma retrogradação transposta da bordadura que não é utilizada em $\mathbf{B}$, além de retomar coleções frígias presente no início da peça. Já o tema $\mathbf{D}$ (cc.51-52) não possui relação motívica evidente com os anteriores. Desta forma, identificamos que não apenas existem importantes relações entre estes temas como também é possível observar uma gradual diminuição na semelhança entre o primeiro tema e os subsequentes.

Pouco a pouco, torna-se claro que aquilo que parecia pertencer apenas ao domínio da forma morfológica (ou seja, apresentações temáticas relacionando-se com a construção arquitetônica da peça) também possui papel formal relevante no domínio da forma cinética, observado aqui na gradual diminuição de similaridade entre os motivos melódicos e o tema inicial. Com isso, observamos a existência de um "consistente padrão de mudanças", fato que, conforme descrito anteriormente, é relevante para o domínio da forma cinética.

Assim, como afirma Richard Parks (1989, p.233), uma unidade formal cinética é definida pelo limite de tendências de diminuição ou de aumento em qualquer parâmetro musical. No exemplo apresentado, os limites em questão são o maior ou o menor grau de proximidade em relação ao primeiro tema, e é possível identificar um padrão de 
afastamento progressivo, ou seja, uma linearidade neste afastamento, que se encerra quando o tema retorna de forma literal no compasso 75 , marcando o fim da exposição. Tal característica da forma cinética, ainda segundo Parks, pode ser percebida como uma sensação de movimento em direção a - ou em direção oposta a - estes limites. Em outras palavras, ela é responsável pela existência de direcionalidade no trecho. Desta forma, fica estabelecida uma sensação de movimento em um plano médio (75 compassos) por conta de uma perda progressiva e um posterior retorno de similaridade com material melódico do início da peça.

Com base nos elementos observados neste capítulo e nas observações relativas às reiterações no capítulo anterior, é possível esboçar alguns princípios composicionais que influenciam ou, possivelmente, determinam o plano médio da peça, ou seja, a primeira seção formal da peça. É possível agrupar os trechos observados anteriormente em dois grupos texturais, que se assemelham por possuírem alguns procedimentos composicionais em comum.

O primeiro grupo será denominado de $\mathbf{A}$ e engloba os cc.1-12 e cc.26-38, tendo as seguintes similaridades:

- Uso da escrita homofônica entre as quatro vozes, reduzindo a independência das linhas melódicas.

- Com maior frequência, a velocidade de mudança harmônica permite que se distingam acordes e, eventualmente, mesmo relações tonais entre acordes.

- A presença literal do tema, que se tornará cíclico ao longo dos movimentos.

- Particularidades na utilização de reiterações e transposições, com predileção pela repetição de trechos pequenos, de até um compasso de duração.

O grupo B, contrastante, é formado pelos cc.13-25 e cc.39-60. Os dois trechos aproximam-se por terem os seguintes aspectos em comum:

- Predileção por um tratamento essencialmente polifônico, com uma melodia acompanhada por rápidos gestos de bordadura.

- O tema do início da peça é observado nestes trechos apenas de forma distorcida, como foi observado na Figura 3.

- A velocidade das bordaduras de acompanhamento impede que o trecho seja percebido como uma sucessão de mudanças de acordes, ficando mais clara uma sensação modal a partir de classes de altura empregadas que se alteram gradualmente. 
- Em relação às reiterações e transposições, em ambos encontramos trechos maiores, de um a quatro compassos, que são reiterados de forma literal, algo menos frequente nos exemplos do grupo $\mathbf{A}$.

O fato de que trechos que possuem processos composicionais similares também tenham semelhanças na forma de utilização de reiterações demonstra que a ênfase (quase obsessiva) que Bourion dá a estas não é exagerada, pois elas podem ser determinantes para (ou talvez determinadas pela) a compreensão de processos composicionais de Debussy.

\section{Processo cinético em um plano médio}

É interessante observarmos que existe um padrão consistente de unidades formais sempre contrastantes que se mantém na primeira seção formal da peça. Trata-se da alternância entre trechos que utilizam os dois processos composicionais descritos anteriormente, A e B (A, cc.1-12, B, cc.13-25, A, cc.26-38, B, cc.39-60). Tal fato é determinante para o conceito de forma cinética da música, pois não apenas a textura geral da peça muda com certa regularidade, mas também ela se alterna entre apenas dois tipos de textura contrastantes.

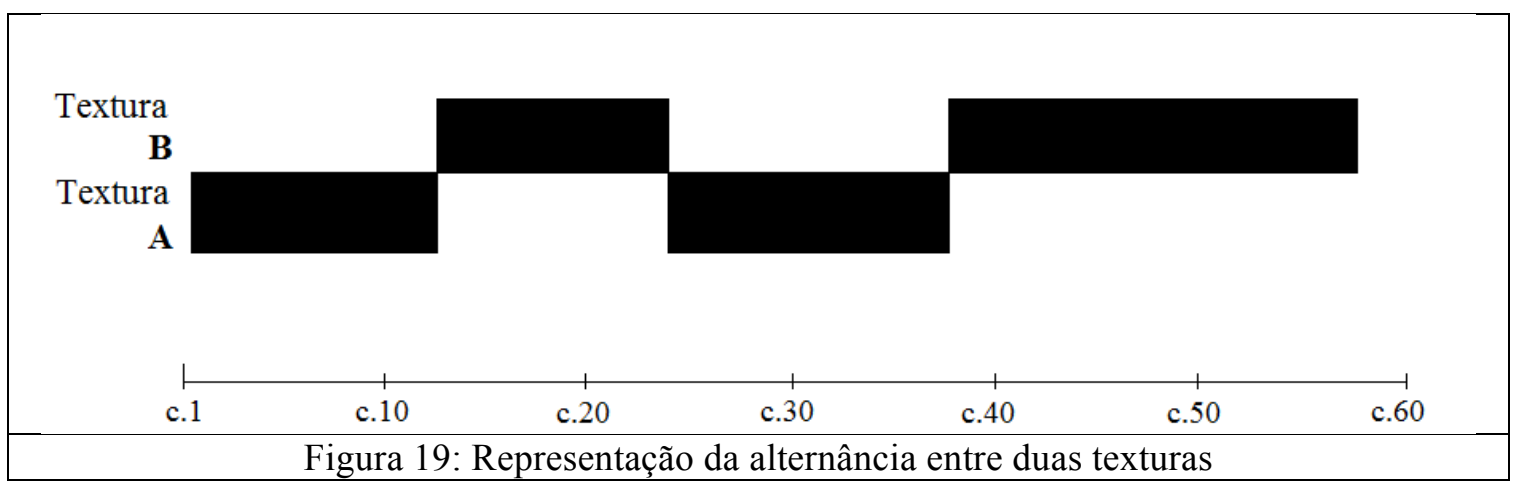

Esta alternância ocorre no mesmo plano formal do processo cinético observado nas primeiras exposições temáticas, onde observamos gradual diminuição na similaridade entre entre os temas nos cc.1-60 (figura 17, p.67). Porém, existe uma diferença fundamental entre os dois processos; enquanto o apresentado acima (Fig. 19) cria uma alternância, ou seja, um movimento periódico que segue um padrão, o processo observado anteriormente (Fig. 18, p. 67 e 68) é caracterizado por sua 
linearidade; ele parte de determinado ponto e se afasta progressivamente deste, encerrando-se em um ponto distante do original. A distinção entre a periodicidade e a direcionalidade dentro de processos cinéticos é de grande importância, pois tratam-se de movimentos bastante diferentes em sua construção (poderíamos dizer que são, em algum nível, opostos: um é linear, não repetido, outro é formado por repetições). Porém, o fato de encontrarmos os dois tipos de movimentos presentes em um mesmo plano formal demonstra de forma significativa a complexidade do processo composicional de Debussy, que não pode ser reduzida a apenas um tipo de movimento.

Nas páginas anteriores pudemos observar de que maneira aspectos relativos à reiteração determinam a forma cinética da peça em um plano médio. Acreditamos que os processos descritos acima sejam determinantes para a sensação de direcionalidade deste trecho. Porém, uma análise que busque atentar-se aos processos influentes na forma cinética ou na direcionalidade percebe rapidamente que existe nestes aspectos um grande dinamismo: assim como observamos uma clara sensação de esgotamento em unidades de 12 compassos (ao longo de sucessivas reduções no tamanho das reiterações), encontramos ao fim dos sessenta primeiros compassos um esgotamento neste padrão de mudanças entre os grupos A e $\mathbf{B}$ e no distanciamento de similaridade melódica. A última apresentação do grupo B (cc.39-60) possui quase o dobro do tamanho de seus anteriores (todos com 12 ou 13 compassos de duração), o que já indica que o processo se encontra saturado e é necessário procurar outras formas de alternância para manter a sensação de movimento ao longo desta peça.

\section{Aspectos relativos à forma cinética na segunda seção formal do Quarteto}

Entre os cc.74-138, encontra-se a segunda seção formal do primeiro movimento do Quarteto. Diferentemente da primeira seção formal, na qual observamos uma alternância regular (a cada 12 compassos, aproximadamente) entre dois tipos de textura, neste trecho é possível observar uma quantidade menor de mudanças no plano textural. Essencialmente, a peça estabiliza-se em uma textura formada por três elementos: linhas melódicas principais, figuras rítmicas de acompanhamento rápidas e repetidas e linhas melódicas de acompanhamento, mais lentas que as linhas principais e, muitas vezes, no baixo. 
Neste trecho, o desenvolvimento temático com base em temas já apresentados continua em evidência e, além de uma apresentação quase literal do tema original (cc.79-80, que neste caso ainda se trata de uma reiteração melódica dos cc.75-76), encontramos o material melódico já presente entre os cc.63-64 e 67-68, repetido exaustivamente neste trecho. Mais uma vez, esse material temático é originário dos quatro primeiros compassos da peça; porém, neste caso, não se trata de um material proveniente da voz melódica principal, e sim de uma figura de acompanhamento presente na viola:

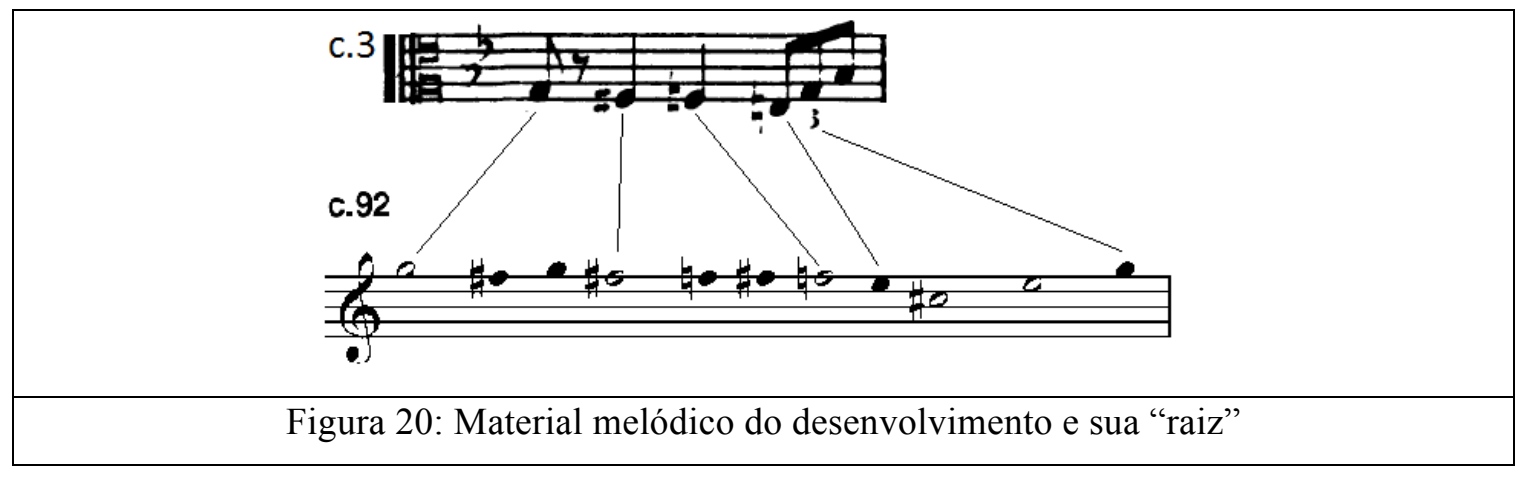

Assim como nos primeiros sessenta compassos, observamos aqui uma grande quantidade de repetições deste material melódico; trata-se de seis transposições por extenso e quatro transposições incompletas do mesmo material em apenas 25 compassos. Apesar das similaridades de contorno melódico, as melodias não são reapresentadas de forma literal; existem diferenças intervalares e transposições significativas entre elas, como mostra a figura a seguir: 


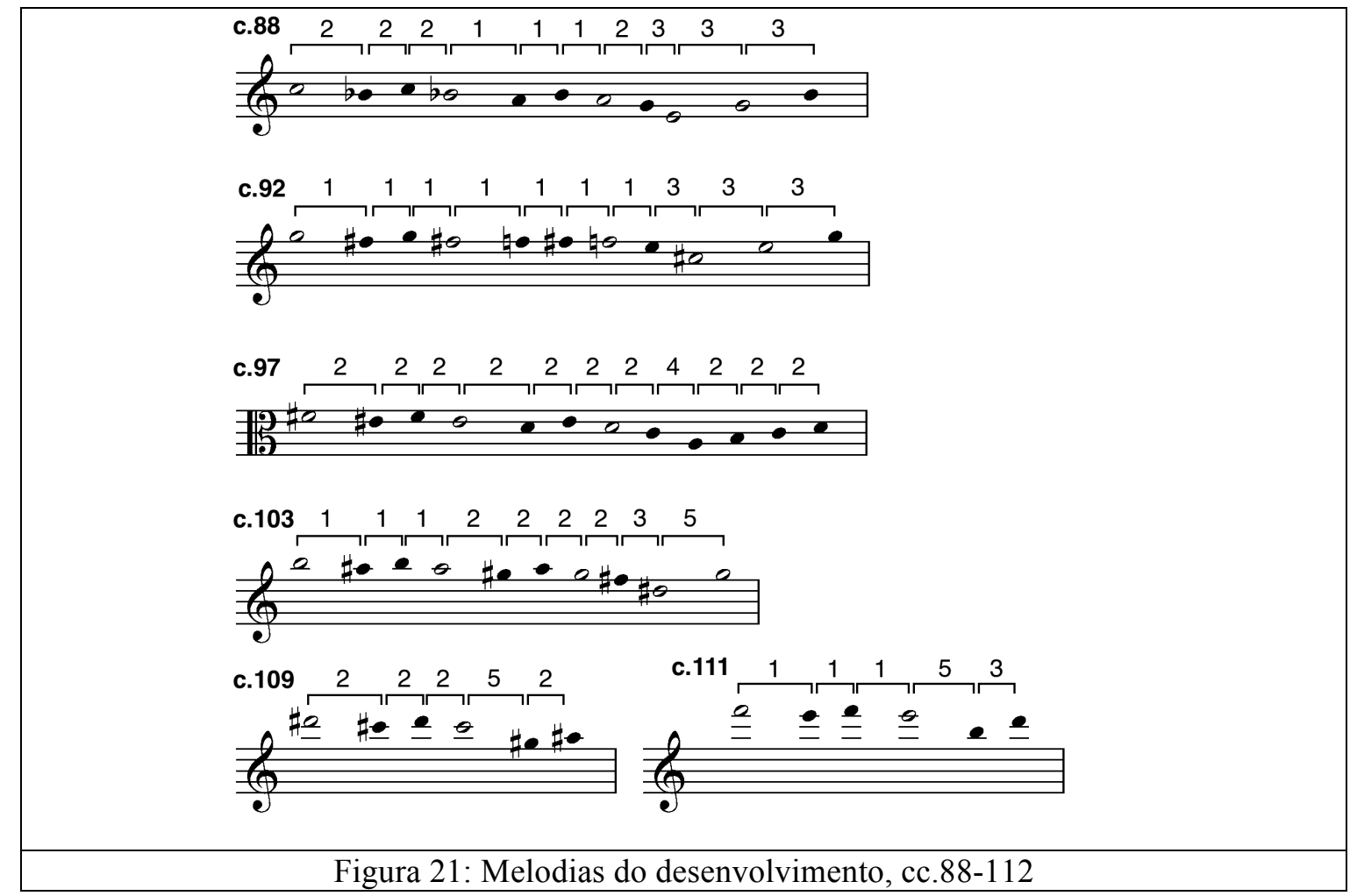

É possível identificar um movimento de contração e expansão nas distâncias intervalares das melodias exemplificadas, algumas com predileção por gestos cromáticos, com intervalos de um semitom entre as primeiras notas, outras com predileção por gestos diatônicos ou de tons inteiros, com intervalos entre um ou dois semitons, no início da melodia. Ao considerarmos que existe uma alternância regular entre estes dois tipos de gestos, identificamos neste processo algo próximo a uma espécie de processo cinético, no qual a alternância entre contração e expansão do material motívico é responsável por uma sensação de movimento, por mais distante da audição que esta sensação de movimento esteja.

No trecho em questão, também é possível notar que cada uma das reapresentações melódicas é acompanhada de um evidente aumento na complexidade harmônica e de escrita, criando um movimento direcional sob este parâmetro. 


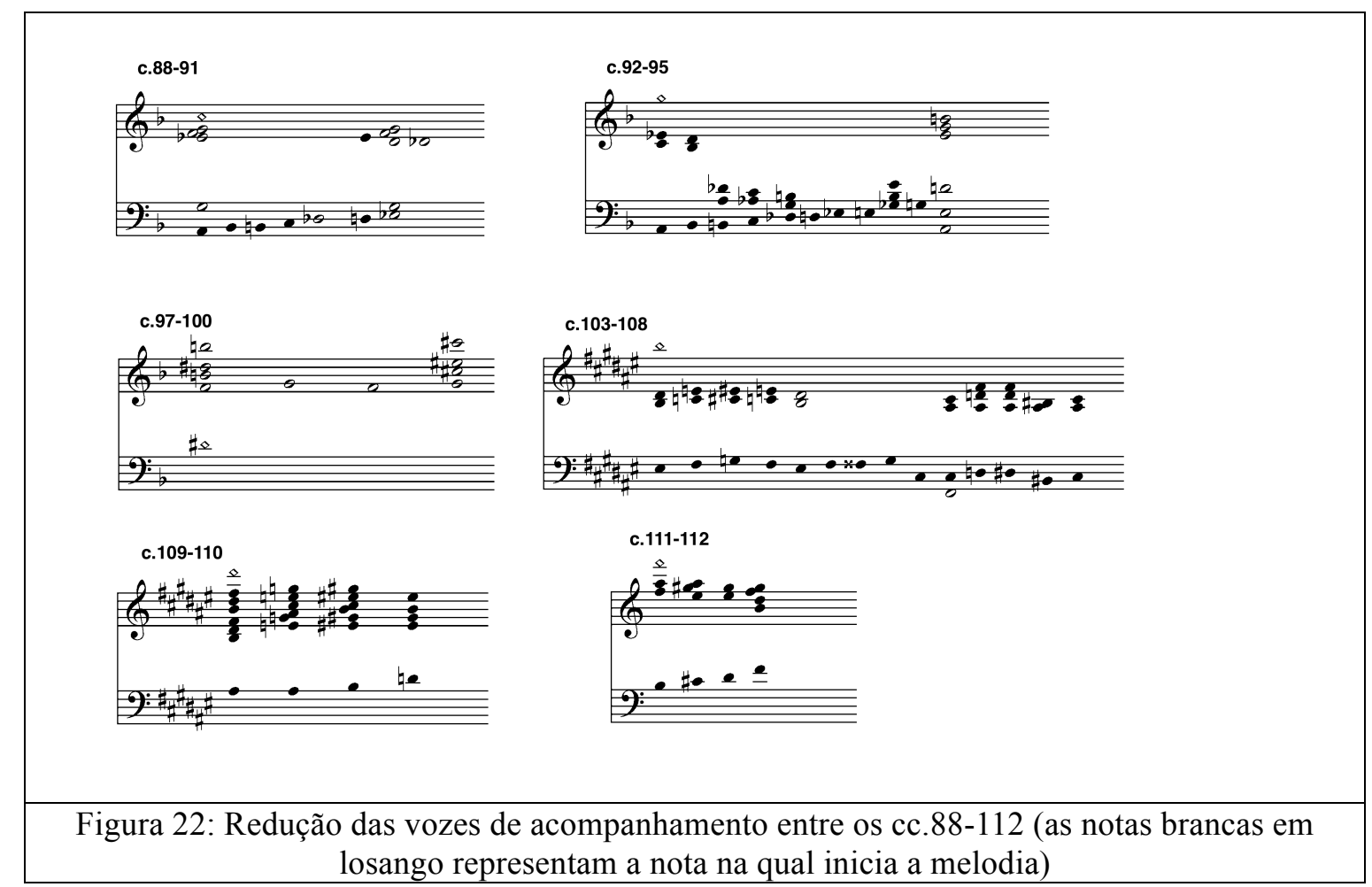

Mais uma vez, podemos observar a coexistência de processos cinéticos periódicos e direcionais em um mesmo plano formal; a alternância entre gestos predominantemente diatônicos ou tons inteiros e cromáticos (periódicos) e o progressivo aumento de complexidade harmônica presente no trecho (direcional).

Observamos também ao longo dos cc.103-118 uma diminuição no tamanho de reiterações, passando de unidades de dois compassos (cc.103-104+107-108), para unidades de um compasso (cc.109+110, 111+112) e, finalmente, unidades de dois tempos (cc.113-116) e 2/3 de tempo (cc.117). Uma comparação entre a utilização de reiterações neste trecho e nos cc.13-25 revela semelhanças nestes aspectos.

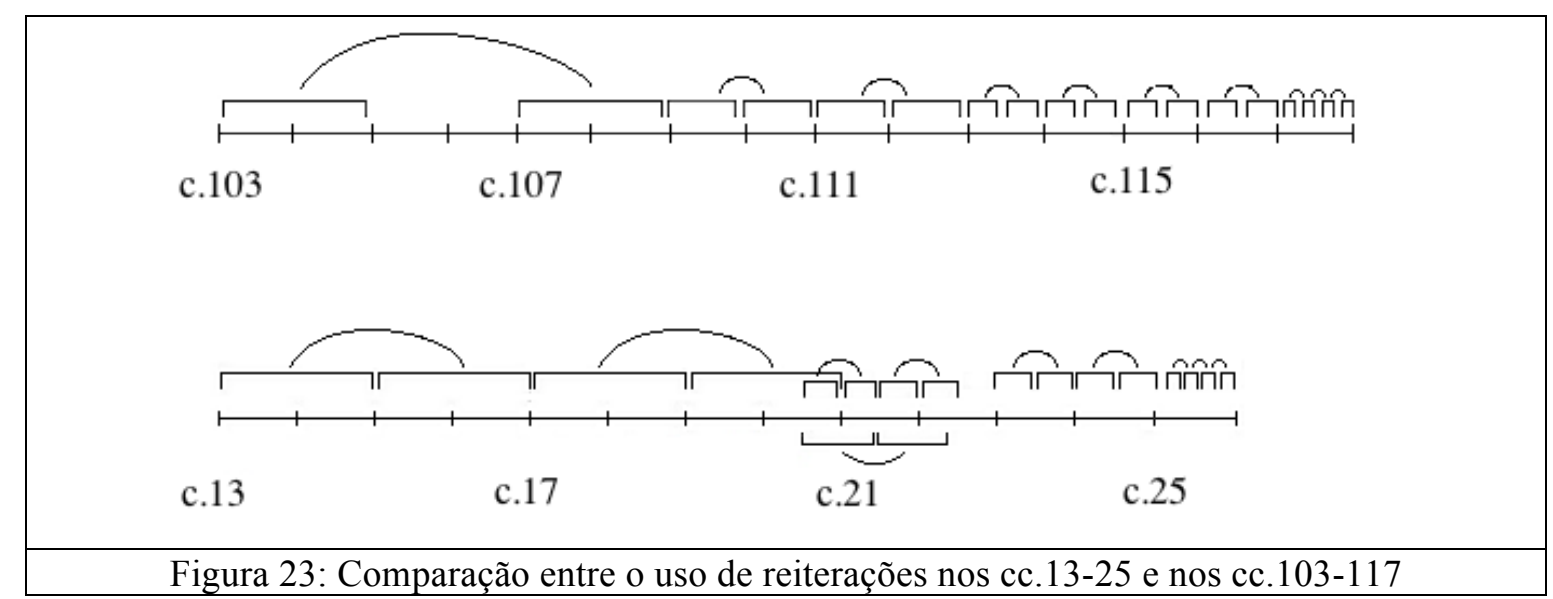




\section{Investigando aspectos relativos à reiteração}

O ponto culminante do trecho encontra-se no início do cc.113, com uma rápida descida em $f \boldsymbol{f}$ que se estende por cinco compassos. Aqui, encontramos não apenas um exemplo interessante de interação entre elementos periódicos e direcionais em pequena escala como podemos localizar também outras formas de repetição ainda mais acentuadas, além da presença de uma espécie de "simetria harmônica" em diferentes planos.

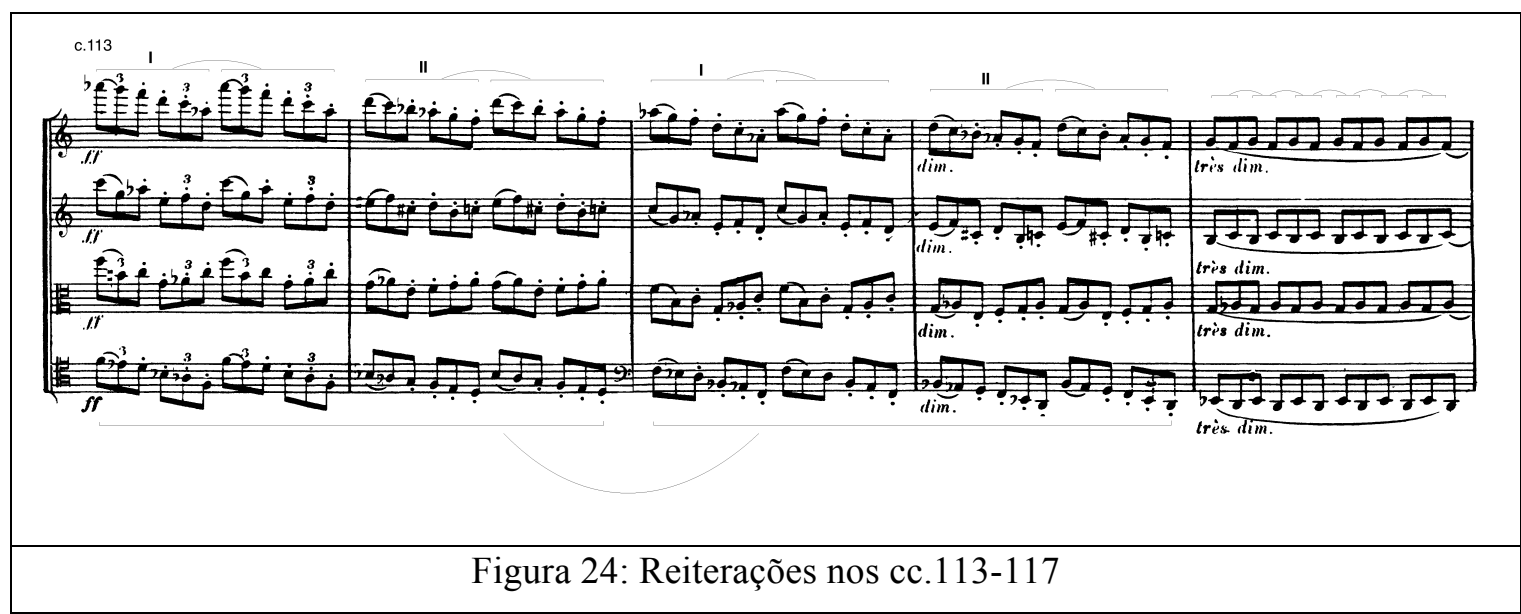

Em uma primeira observação, é possível identificar o fato de que os dois últimos tempos dos cinco compassos em questão são sempre reiterações literais dos primeiros dois tempos dos mesmos compassos. Porém, também existem outras formas de repetições em diferentes planos, com diversos níveis de sutileza. Notamos, por exemplo, o fato de que o terceiro e quarto compassos são repetições literais do primeiro e segundo, porém com todas as classes de alturas transpostas em uma oitava para o grave. Com isso, todo o material "original" do trecho resume-se a dois gestos com dois tempos de duração, classificados como I e II na Figura 23 (ou seja, todos os outros gestos são reiterações literais ou transposições em oitava destes dois gestos).

Menos evidente que isso é o fato de que, em suas vozes extremas, o gesto II é uma reiteração quase literal do gesto I, porém com uma inversão de localidade; as 
classes de alturas presentes no primeiro tempo agora se encontram no segundo tempo e vice-versa ${ }^{23}$ (figura seguinte).

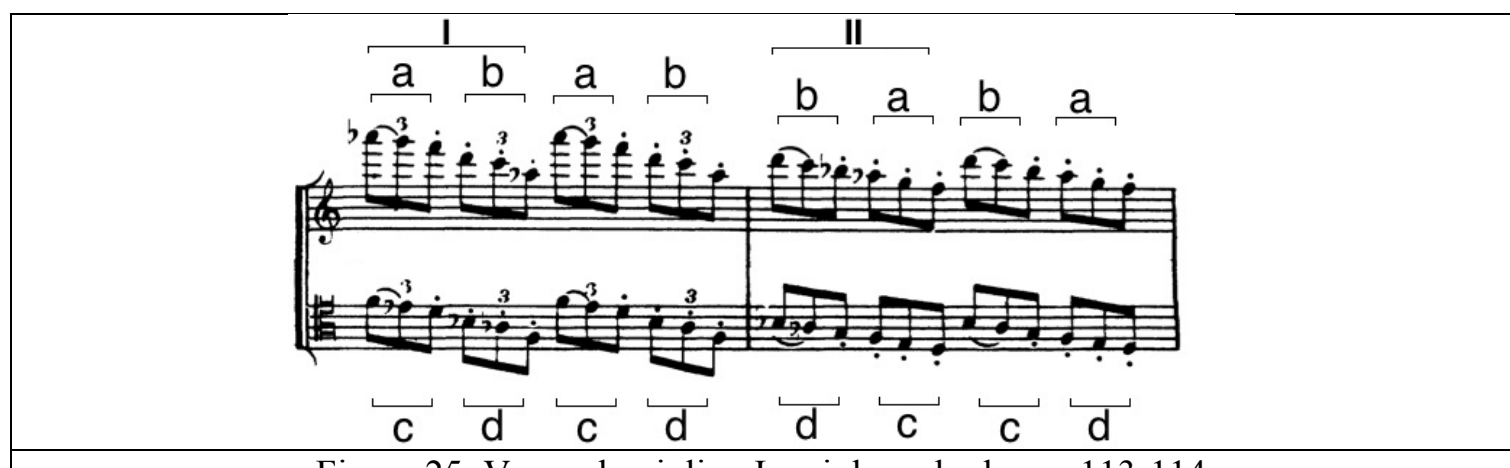

Figura 25: Vozes do violino I e violoncelo dos cc.113-114

Também podemos notar que ainda que o trecho aparente possuir denso conteúdo harmônico, a repetição de classes de alturas encontra-se em um nível ainda mais profundo: entre todas as classes de alturas apresentadas no trecho, existe uma constante alternância entre grupos com as alturas fa-láb e grupos com as alturas mi-sol (indicado pelas notas brancas da Figura 25).

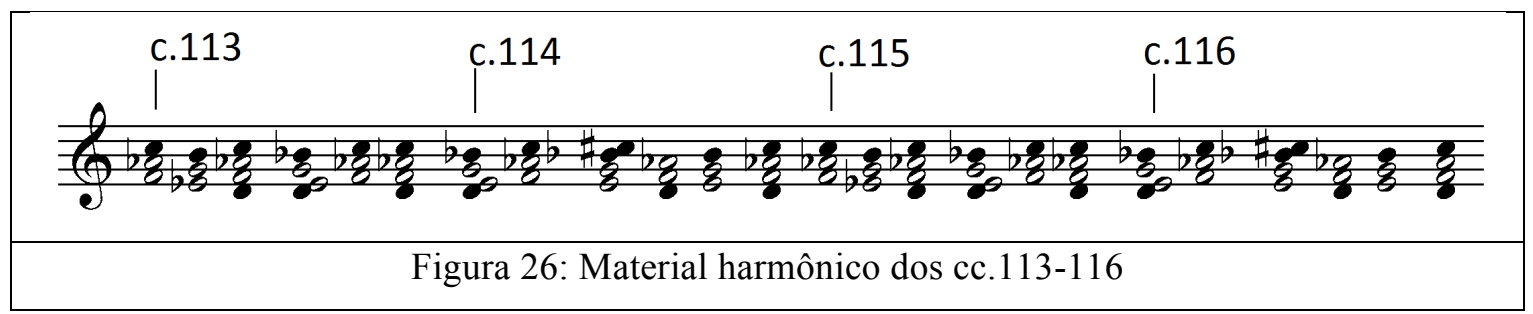

Esta espécie de padrão de bordadura entre estes dois grupos de acordes modifica-se apenas no último tempo de cada compasso, possivelmente com o intuito de fazer com que o próximo compasso inicie com outro grupo de acordes, diferenciando-o assim do compasso anterior. Tal padrão antecipa o gesto do c.117, formado por reiterações semelhantes às presentes apenas harmonicamente na figura acima. Quando observamos o trecho em diferentes planos formais (em micro e pequena escala), isso

23 Ao levarmos em conta as vozes intermediárias (violoncelo e viola), os gestos mantêm os mesmos padrões descritos acima, porém, algumas classes de alturas são modificadas. Existe apenas uma classe de altura do grupo b e outra do grupo d que não são idênticas nos dois gestos; em I, b é formado por ré, do, láb, enquanto em II, é formado por ré, do, sib. No grupo I, d é formado por sib, láb, fá, enquanto em II, é formado por sib, láb, sol. É interessante notar que mesmo esta alteração ocorre de forma simétrica, na mesma localização temporal em ambos os grupos, possivelmente para permitir que ocorram alguns procedimentos harmônicos como os observados na sequência. 
acaba por criar outros padrões interessantes, nos quais diferentes figuras de bordadura podem ser observadas, sempre com as mesmas notas em destaque.

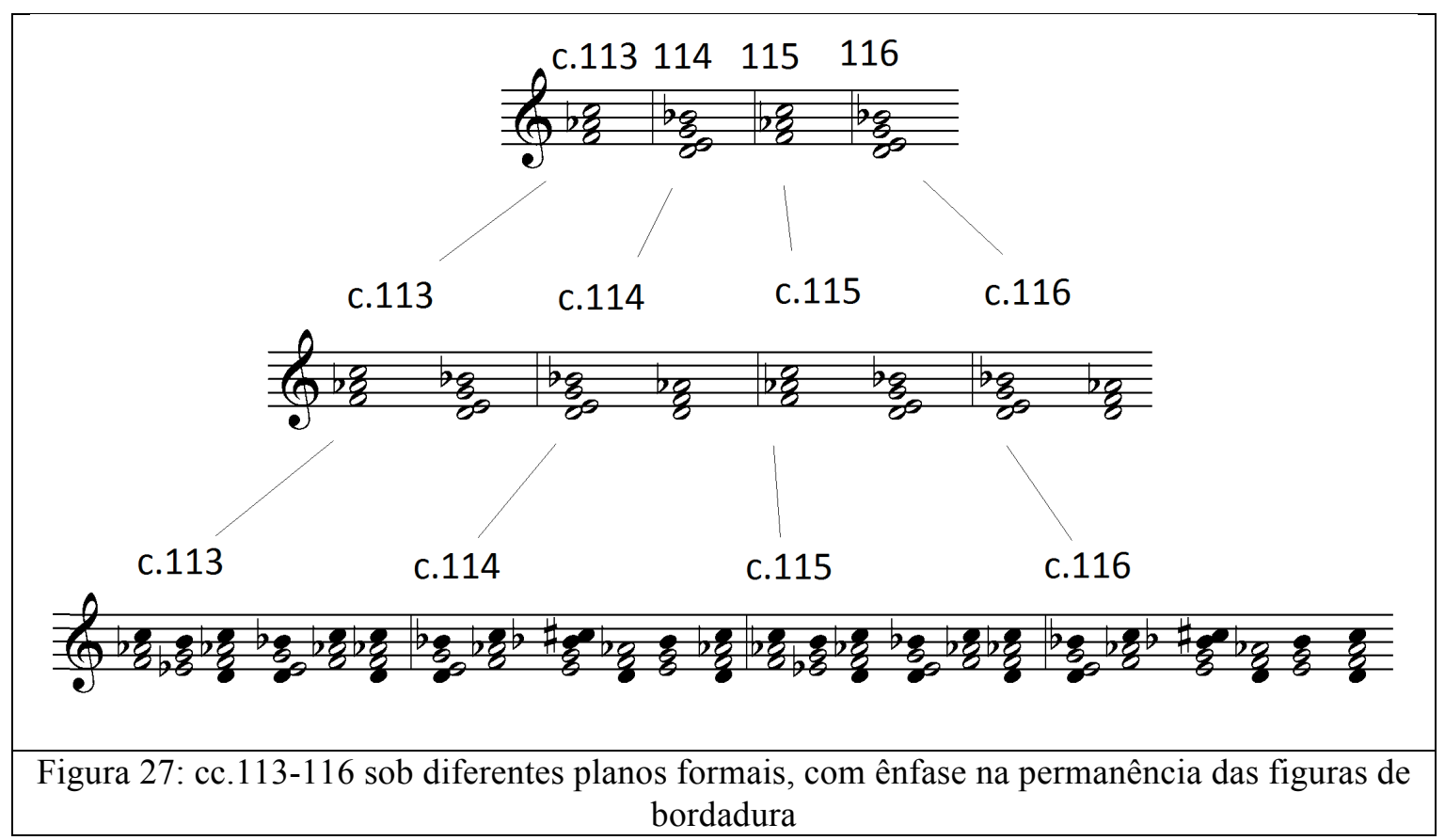

Observamos assim que entre os cc.113-116, a repetição encontra-se em níveis mais elevados do que ela aparenta em uma primeira escuta. Tal fato faz com este trecho assemelhe-se ao compasso 25: ambos são pequenos trechos ao final de uma unidade morfo-cinética, que aparentam ser compostos por uma grande diversidade de elementos, mas são, na realidade, composto por poucos elementos modificados por meio de permutações, transposições e reiterações. É possível então conceber este trecho como uma ampliação de um processo composicional semelhante ao encontrado no c.25.

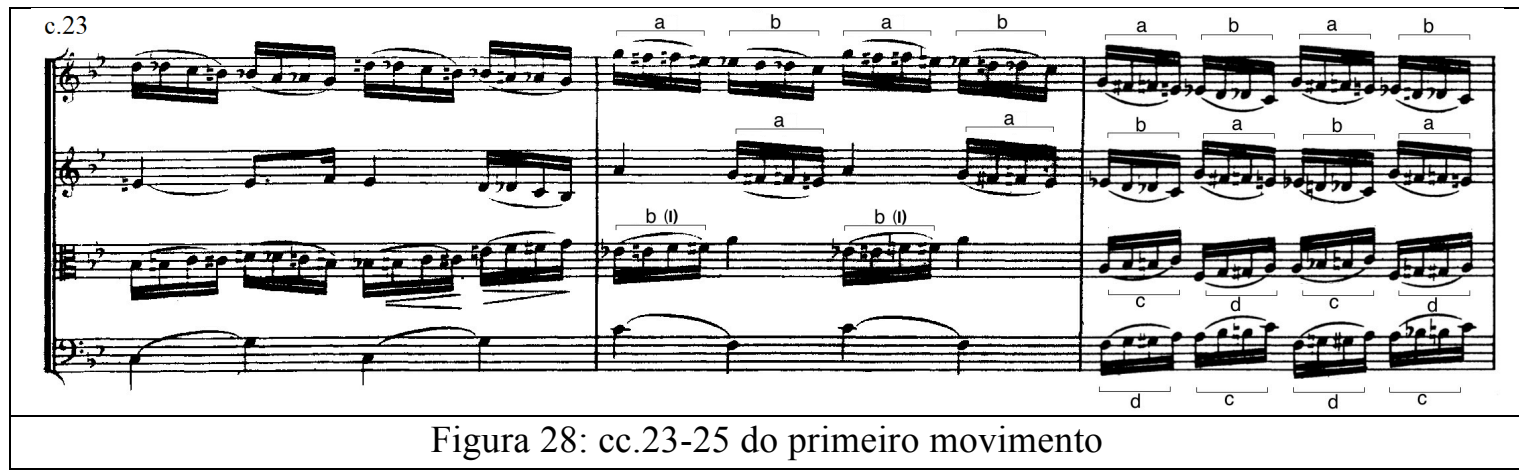

Os procedimentos descritos acarretam um aumento na sensação de direcionalidade do trecho em sua totalidade (cc.88-117) devido aos seguintes fatores: 
- Diminuição progressiva no tamanho das unidades reiteradas.

- Aumento da complexidade harmônica.

- Forte presença de simetria e reiterações (em diferentes níveis) ao final das duas unidades.

Observaremos a seguir mais um exemplo de uma espécie de bordadura harmônica, semelhante à observada anteriormente. Tal bordadura encontra-se em um plano formal mais amplo e consequentemente mais distante do plano auditivo.

\section{Bordaduras harmônicas em um plano elevado}

O trecho logo após a rápida descida dos cc.113-116 (figura 23) é marcado por uma brusca mudança em todos os parâmetros musicais e pode ser visto como uma espécie de preparação para o final do desenvolvimento e início da recapitulação. Encontramos uma grande quantidade de silêncio nas vozes, e todas elas se encontram nas regiões graves de seus respectivos instrumentos em uma dinâmica entre $p$ e $p p$.

Curiosamente, também é o trecho que possui a reiteração mais longa de todo o movimento, com duração de seis compassos, o que reforça a ideia de que quanto menores as reiterações, maior é a sensação de movimento do trecho. Nele há uma reiteração transposta (cc.120-125+126-131) na qual observamos um procedimento inédito na peça; uma transposição de todas as vozes com exceção da do baixo, que se mantém fixa em um pedal.

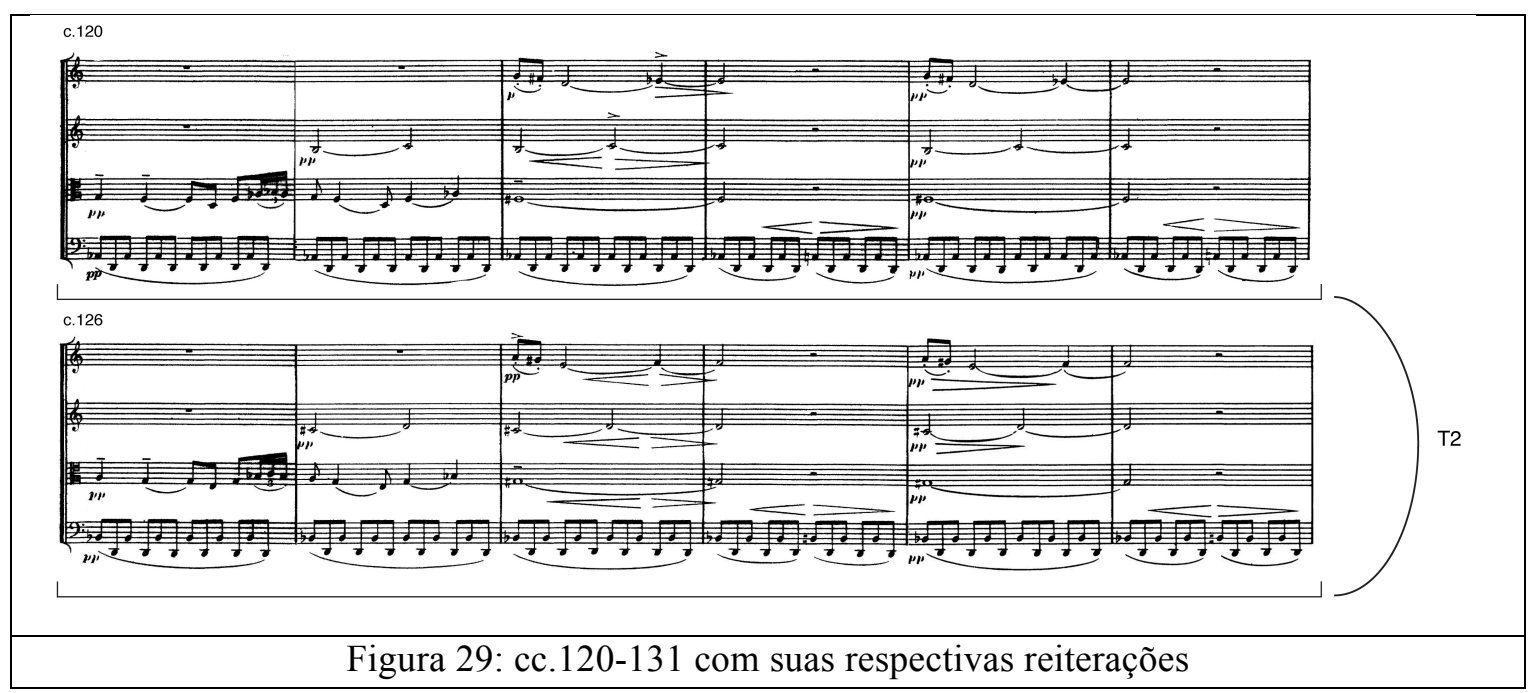


Uma espécie de alternância, ainda mais distante do plano sonoro, pode ser observada aqui. O trecho apresenta o tema inicial da peça duas vezes, a primeira partindo da nota sol, e a segunda, sua transposição, partindo da nota lá. Sempre após as apresentações temáticas encontramos um novo gesto, também reiterado, formado por um fragmento temático. O fato de ocorrer uma transposição com um pedal fixo, ou seja, uma reiteração em que algumas vozes são transpostas e outras se mantêm, acaba por criar uma espécie de bordadura harmônica, ainda mais distante do plano auditivo, pois as semelhanças encontram-se no conjunto de classes de alturas das vozes harmônicas do trecho que são repetidas com sua ordem invertida, como mostra a Figura 27.

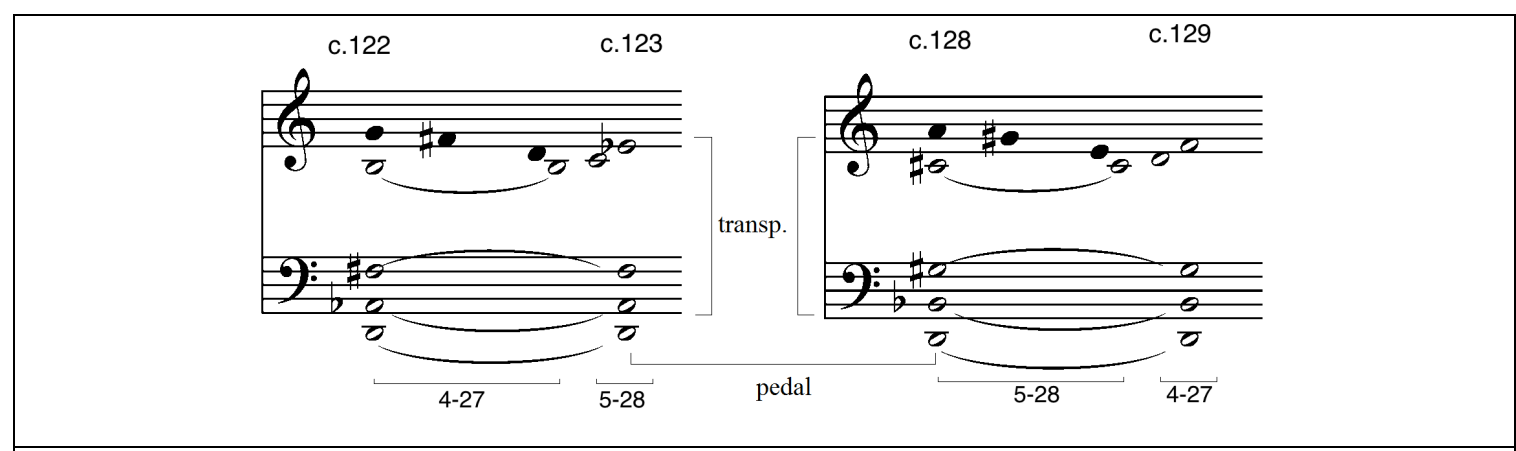

Figura 30: Alternância entre conjuntos de classes de alturas dos cc.122-123 e 128-129

Mais uma vez, encontramos antes da terceira seção formal da peça um rápido aumento na quantidade informações aliado a uma fragmentação do material melódico que havia sido apresentado anteriormente (apenas um compasso do tema inicial é ligado ao fragmento temático presente nos cc.88-112). Os dois últimos compassos do trecho, cc.136-137, possuem características de "sonoridades de transição" semelhantes aos cc.25 e 113-117 observados anteriormente: trechos homofônicos com alto índice de reiteração, consequentemente, uma menor quantidade de informações novas.

Neste trecho também observamos uma reiteração transposta uma oitava abaixo, semelhante à presente nos cc.113-116 (p.73). Inicialmente, as alturas presentes nestes dois compassos aparentam formar dois tipos de acorde (A e B na figura seguinte). Porém, logo se observa que ambos são compostos pelas mesmas classes de alturas dispostas de maneira diferente. Além da modificação rítmica do c.137, também observamos uma mudança nas vozes internas do trecho que não altera a disposição das classes de alturas em questão, mas sim qual o instrumento que as executa. Isso proporciona uma sensação de movimento sem que exista, de fato, uma movimentação harmônica, procedimento já observado em exemplos anteriores. 
Novamente, é possível identificar uma simetria horizontal entre o movimento de vozes, com um eixo de espelhamento entre o violino II e a viola. Neste caso, a simetria também se encontra no âmbito harmônico, pois o acorde em questão, classificado como 4-25, possui características de tons inteiros, sendo formado por dois intervalos de trítono separados por uma segunda maior. O conjunto possui propriedades simétricas por invariância em $T_{6}$, e por invariância e inversão em $T_{4} I$ e $T_{10} I$.

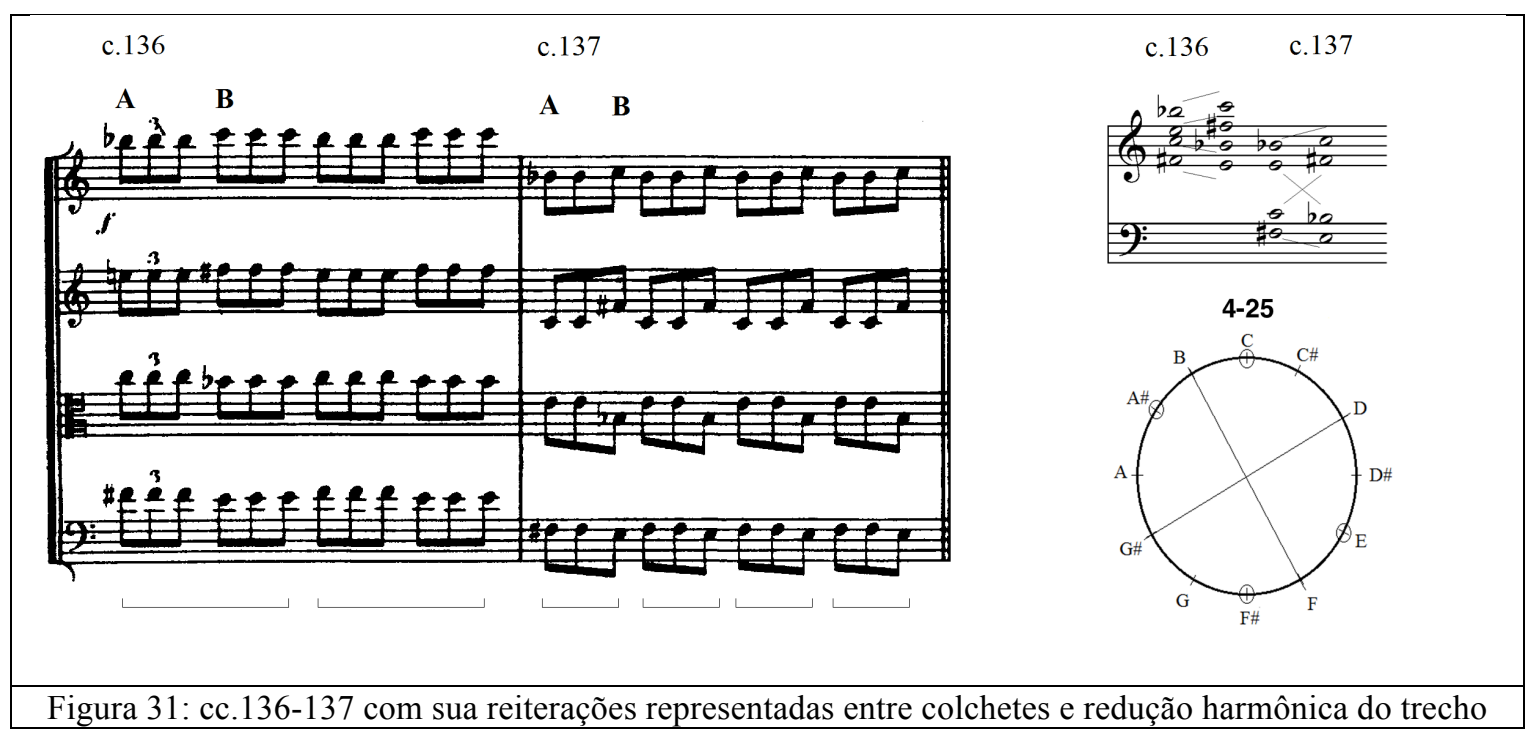

\section{Terceira seção formal}

Entre os cc.138-180, encontra-se a terceira seção formal do Quarteto, identificada por Parks como a recapitulação da forma sonata. Nela, os diversos processos composicionais descritos anteriormente se encontram presentes e de maneiras semelhantes às anteriormente observadas. Por isso, acredita-se que seja mais interessante atentar a outros elementos deste trecho e do primeiro movimento do Quarteto.

Apesar de existir de fato uma reapresentação melódica do tema inicial completo no início desta seção, tal elemento parece ser o único que nos permite afirmar que se trata, de fato, de uma reexposição nos moldes de uma forma sonata, pois não é possível localizar de maneira explícita nenhum outro elemento temático ou formal que ligue este trecho ao trecho da exposição inicial. A peça continua a utilizar os mesmos procedimentos presentes entre os cc.75-137, ou seja, desenvolvimentos temáticos 
baseados em elementos presentes anteriormente. Os principais materiais melódicos presentes no trecho encontram-se na figura seguinte.

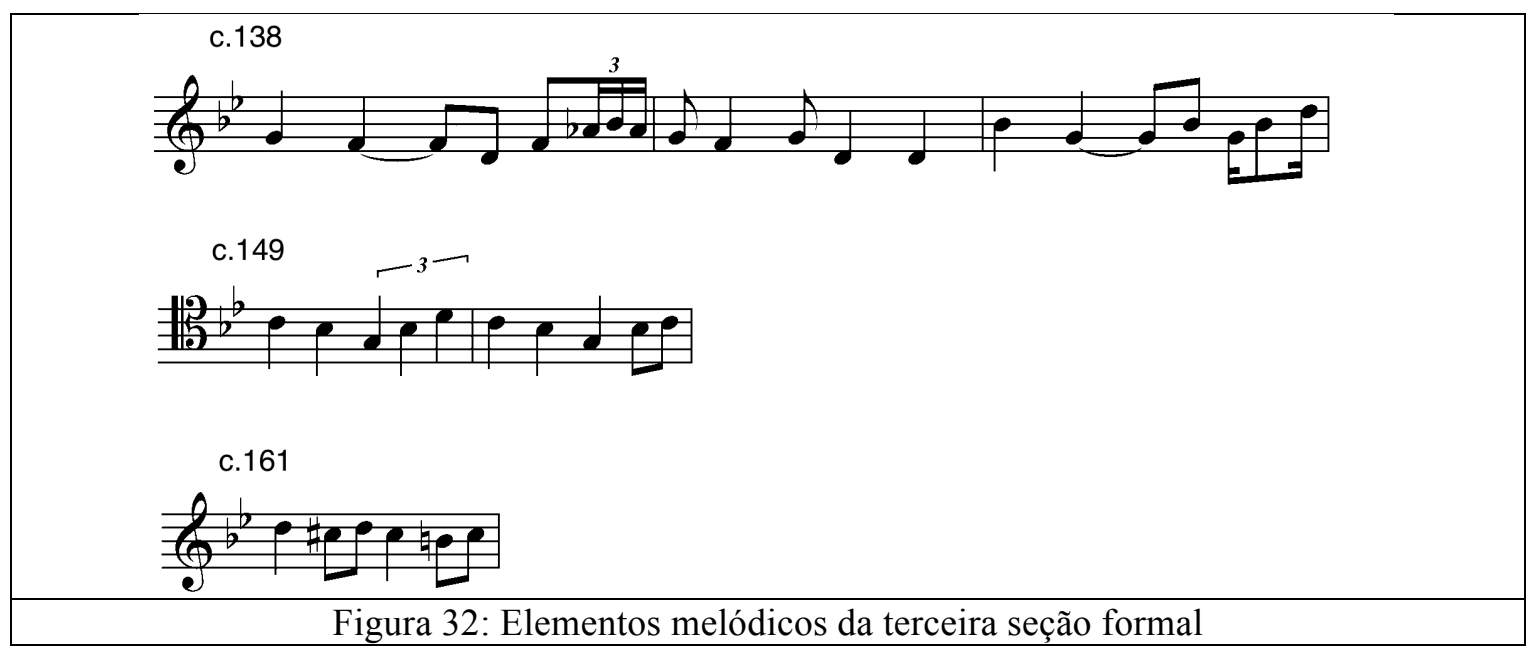

Não é difícil identificar as semelhanças entre as melodias acima e os elementos temáticos observados anteriormente; trata-se de distorções do tema inicial e do fragmento do c.3 da voz da viola (figura 19, p.71). Tanto o primeiro quanto o segundo gesto são reiterados (com transposições) quatro vezes enquanto o terceiro gesto é repetido três vezes. Um elemento recorrente no trecho que é pouco observado anteriormente são subidas cromáticas entre os cc.145-146 e cc.171-174 (na primeira delas observamos três reiterações literais transpostas sempre um semitom acima, algo inédito na peça). Esse fato é um dos principais elementos responsáveis pelo aumento de tensão na peça, que vai culminar na rápida descida pentatônica entre os cc.183-190.

\section{A análise paradigmática segundo Bourion}

A principal ideia desta pesquisa é investigar de que maneira alguns aspectos específicos se comportam no primeiro movimento do Quarteto de cordas em sol menor de Debussy. Longe de tentar explicar completamente o movimento, enfatizaram-se aqui aspectos relativos a reiterações, simetrias e também alguns aspectos harmônicos, principalmente quando estes se encontram aliados a um ou aos dois elementos citados acima. Se, sob estes aspectos, acreditou-se cobrir os pontos de maior destaque da peça, importantes elementos tornam-se mais claros ao revermos estes conceitos por meio de uma análise paradigmática, elemento proposto por Bourion originalmente com o intuito 
de elucidar o papel das reiterações na música, que será utilizado aqui para uma melhor compreensão de aspectos formais do Quarteto.

A técnica de análise paradigmática consiste em identificar unidades que pertencem a um mesmo paradigma, ou seja, elementos que apresentam diversas ocorrências na obra. Nós reescrevemos então a peça sobre a forma de uma tabela paradigmática que apresenta, repete ou transforma, em uma mesma coluna, diferentes ocorrências apresentadas na obra analisada. Esta decupagem consistirá no reconhecimento de similitudes internas de unidades constitutivas do discurso. (BOURION, 2011, p.21)

Para realizar uma decupagem paradigmática é necessário separar os momentos da peça em diferentes categorias ou paradigmas. Estas categorias podem ser identificadas por diferentes tipos de semelhanças, sejam elas texturais, harmônicas, melódicas ou de outras ordens. Utilizaremos nesta decupagem paradigmática uma separação entre os tipos de texturas observadas anteriormente: trechos homofônicos em que existe uma clareza tonal ou modal, trechos de melodia acompanhada, usualmente com figuras de ostinato no acompanhamento, sonoridades de transição situadas ao final de unidades formais, sempre homofônicas e tonalmente ambíguas, e texturas intermediárias, próximas de mais de uma categoria mencionada ou cuja formação não se encaixa em nenhuma delas.

A tabela paradigmática deixa claro de que maneira a peça se alterna entre as diferentes categorias, apontando também o tamanho de cada unidade (em negrito na figura seguinte). Demonstrando esta alternância entre diferentes categorias e mesmo modificações entre elementos da mesma categoria, é possível elucidar como estes elementos se relacionam com o processo composicional de Debussy.

Paradigma A: trechos homofônicos: cc.1-5, cc.26-38, cc.75-78, cc.138-139, cc.181-194 -38 compassos.

Paradigma B: melodias acompanhadas: cc.13-22, cc.39-73, cc.79-95, cc.97-100, cc.103-112, cc.120-135, cc.149-169, cc.171-180- 123 compassos.

Paradigma C: sonoridades de transição: cc.23-25, c.74, cc.101-102, cc.113-117, cc.136-137 - 13 compassos.

Paradigma D: texturas intermediárias: cc.6-12, cc.96, cc.118-119, cc.140-148, c.170 20 compassos. 


\begin{tabular}{|c|c|c|c|}
\hline Paradigma A & Paradigma B & Paradigma $\mathrm{C}$ & Paradigma D \\
\hline \multicolumn{4}{|l|}{ Seção 1} \\
\hline \multirow[t]{2}{*}{ cc. $1-5(5)$} & & & cc.6-12(7) \\
\hline & cc.13-22 (10) & cc.23-25 (3) & \\
\hline cc.26-38 (13) & cc.39-73(35) & cc.74 (1) & \\
\hline \multicolumn{4}{|l|}{ Seção 2} \\
\hline \multirow[t]{4}{*}{ cc.75-78 (4) } & cc.79-95 (17) & & cc.96(1) \\
\hline & cc.97-2100 (4) & cc.101-102 (2) & \\
\hline & cc.103-112 (10) & cc.103-117 (15) & cc.118-119(2) \\
\hline & cc.120-135 (16) & cc.136-137 (2) & \\
\hline \multicolumn{4}{|l|}{ Seção 3} \\
\hline \multirow[t]{3}{*}{ cc.138-139(2) } & & & cc.140-148(9) \\
\hline & cc.149-169 (21) & & cc.170 (1) \\
\hline & cc.171-180 (10) & & \\
\hline cc.181-194 (14) & & & \\
\hline
\end{tabular}

\section{A forma sonata dentro do Quarteto}

Com base na figura anterior, é possível afirmar que existe consistência tanto na divisão da peça entre três grande seções (como foi feito por Parks), quanto na divisão entre os paradigmas mencionados, pois fica claro que existem mudanças no padrão de utilização dos diferentes paradigmas a cada mudança de seção. Já foi observado que, na primeira seção formal da peça, a alternância entre trechos pertencentes ao paradigma $\mathbf{A}$ e trechos pertencentes ao paradigma $\mathbf{B}$ é essencial para a forma cinética da peça, e que este tipo de alternância não se mantém ao longo da segunda seção formal, que é marcada por alternâncias entre os paradigmas $\mathbf{B}$ e $\mathbf{C}$, como demonstra a figura anterior. A última seção formal da peça não retoma o padrão presente no início da peça, mas mantém uma textura próxima à da segunda seção formal, porém deixando de utilizar os elementos homofônicos e tonalmente ambíguos do paradigma $\mathbf{C}$ e retomando a homofonia modal/tonal do paradigma $\mathbf{A}$ apenas ao final da peça (é possível recordar a citação de Lockspeiser (1936, p.153), no Capítulo 1, na qual o autor menciona que, ao final da segunda seção do quarteto, somos "[fascinados] por um pouco mais de tempo por outras variações, desenhos e mutações harmônicas"). Também podemos observar que a maior parte das três seções é formada por trechos pertencentes ao paradigma B; porém, todas se iniciam com o paradigma $\mathbf{A}$ e terminam ou com o mesmo paradigma ou $\operatorname{com} \mathbf{C}$. 
A falta de similaridade entre a primeira e a última seção formal reforça a ideia de que, nesta peça, a forma sonata não deve ser vista como um elemento de grande força estrutural. Se fosse este o caso, observaríamos uma quantidade maior de elementos da primeira seção retornando em sua última parte e não apenas o tema presente nos quatro compassos iniciais apresentado em um contexto textural diferente.

Uma possível razão para esta aparente falta de rigor com a forma sonata é o fato de o Quarteto de Debussy ter sido composto no final do século XIX e encontrar-se ligado ao estilo na moda neste período, no qual o rompimento com estruturas preestabelecidas era valorizado (foi observado no Capítulo 2 o comentário de Charles Rosen, segundo quem o compositor do final do século XIX era interessado pela ruptura de uma forma padrão). Neste sentido, a utilização de uma forma sonata mais convencional poderia ser vista como uma espécie de tradicionalismo pouco interessante para o compositor ${ }^{24}$.

A relação entre inovação, ruptura e tradicionalismo é particularmente interessante no Quarteto de cordas em sol menor de Debussy, pois aparenta estar carregada de contradições. Ao empregar a forma cíclica, Debussy utiliza um modelo formal bastante próximo a ele (o compositor César Franck) e o utiliza de maneira praticamente literal, conforme observou Wheeldon (2005, p.646). Com relação à forma sonata, esta se encontra enfraquecida e não possui um modelo formal claro, porém isso também é condizente com o período em que a peça foi composta (assim como é condizente utilizar o modelo formal de Franck). Já o seu padrão no uso de reiterações dentro da música - na qual encontramos um grande número de reiterações em um plano microestrutural, diminuindo a quantidade de reiterações em maior escala - aproxima o Quarteto de peças mais tardias de sua carreira, nas quais tal tipo de procedimento é mais frequente.

Outras análises do Quarteto, observadas no primeiro capítulo, também reforçam esta interessante dicotomia entre tradição e ruptura. Lockspeiser afirma que o Quarteto possui uma forma semelhante a "pequenos mosaicos", qualidade associada a peças da maturidade de Debussy como Jeux ou alguns de seus prelúdios. Porém, dentro destes mosaicos, encontramos temas que ainda são basicamente morfológicos: contornos,

24 Seria possível indagar se a utilização da forma cíclica, com seus constantes desenvolvimentos temáticos, não acabaria impossibilitando uma utilização mais conservadora da forma sonata, e por esta razão a forma sonata acaba perdendo força nesta peça. Observaremos a seguir, porém, que os dois modelos formais não apenas são compatíveis como também são integrados de maneira bastante peculiar em peças do final da carreira do compositor. 
harmonia e proporções duracionais são características cuja superfície varia, mas o contorno estrutural não (PARKS, 1989, p.338). Esta característica é rompida em obras posteriores do compositor, nas quais timbres e sonoridades ocupam o lugar de elementos "morfológicos" na estrutura musical das obras ${ }^{25}$.

As dicotomias mencionadas apontadas levam-nos à conclusão que o Quarteto de cordas em sol menor de Debussy pode ser visto como uma obra de transição entre o período de juventude e o período de maturidade do compositor ${ }^{26}$. Neste sentido, é enriquecedor para a pesquisa observarmos em um plano formal mais amplo de que maneira os elementos pesquisados no Quarteto se manifestam em peças de um período posterior de sua carreira, e especialmente em obras que possuam esquemas formais semelhantes ao do Quarteto. Para tanto, utilizaremos o primeiro movimento de sua Sonata para flauta, viola e harpa, peça composta ao final de sua carreira que utiliza padrões formais semelhantes aos do Quarteto. Compreendendo as mudanças existentes na utilização de modelos formais das duas peças, será possível jogar luz sobre o papel que a tradição musical exerce no processo composicional de Debussy e fortalecer a ideia de que, "em Debussy, processos composicionais não são substituídos; eles vão se sobrepondo" (PARKS, 1989, p.XII).

\section{Uma breve comparação entre os primeiros movimentos do Quarteto em sol menor e da Sonata para flauta, viola e harpa}

Entre 1914 e 1918, Debussy compôs três importantes peças, chamadas informalmente de "três sonatas de câmara": Sonata para violino e piano, Sonata para violoncelo e piano e Sonata para flauta, viola e harpa. Nestas três peças, é possível observar uma retomada de procedimentos pouco vistos em obras de Debussy dos primeiros anos do século XX: a utilização do gênero música de câmara, o emprego frequente de elementos pertencentes ao tonalismo e a utilização da forma cíclica na

25 Segundo Wheeldon, o Quarteto já possui características que permitem que se coloque o timbre como elemento formal desta peça, como foi observado no início do segundo capítulo. Porém, trata-se de uma característica presente apenas em um plano formal em larga escala, observado entre os diferentes movimentos, e não dentro de um elemento motívico, que é o foco da citação de Parks.

26 Para esta categorização entre períodos composicionais de Debussy utilizamos a divisão realizada por Benedetti, que separa as obras de Debussy em três períodos: obras de juventude (1880-1887), obras de maturidade (1887-1913) e obras de síntese (1914-1917) (BENEDETTI, 2005, p.876-877). 
composição da peça. Ainda que o primeiro movimento da Sonata para flauta, viola e harpa, Pastoral, tenha um caráter lento e suave, diferente do primeiro movimento do Quarteto (diferença esta que pode estar ligada às suas influência composicionais, como observaremos adiante), acreditamos ser interessante uma comparação entre esta obra e o primeiro movimento do Quarteto. Nestas duas peças encontramos os dois requisitos mencionados: trata-se de peças situadas em polos opostos da cronologia do compositor e ambas são peças de música de câmara em que é possível observar o emprego de elementos tonais e a forma cíclica. As diversas mudanças na utilização dos elementos citados nos diferentes períodos podem ser importantes ferramentas para compreender modificações mais amplas no pensamento composicional de Debussy.

\section{Influências na forma cíclica da sonata para flauta, viola e harpa}

Se, durante o período de composição do Quarteto, Debussy tinha em Franck um de seus principais modelos para a utilização da forma cíclica, existiam em 1914 questões que dificultavam esta aproximação, o que fez com que outras referências surgissem para este modelo composicional:

Depois da morte de Franck, em 1980, [Vincent] d'Indy encarregou-se de promover o legado de seu professor [Franck], tanto em suas aulas na Schola Cantorum quanto no Cours de composition musicale, um tratado de quatro volumes baseado em seu currículo na escola. D'Indy compilou suas aulas (com a ajuda de seu aluno Auguste Sérieyx) em vários volumes do Cours, sendo o primeiro impresso em 1903. O capítulo intitulado La Sonate cyclique - baseado nas aulas de d'Indy na Schola Cantorum de 1989 a 1900 - encontra-se no volume 2, parte 1, publicado em 1909. (WHEELDON, 2005, p.659)

A visão histórica de Vincent d'Indy sobre a sonata cíclica, presente em suas aulas e livros, encontra-se fortemente influenciada por um nacionalismo exacerbado, com predileção por compositores franceses, em detrimento de compositores pertencentes à tradição germânica. Segundo ele, nenhum compositor alemão do século XIX trouxe importantes contribuições para este modelo e, desta forma, "a tradição cíclica pode ser considerada como transmitida diretamente de Beethoven a César Franck" (WHEELDON, 2005, 661).

Possivelmente com o objetivo de não ser associado a uma tradição que se inicia em Beethoven e termina na Moderna Escola Francesa, Debussy opta pela adoção de 
modelos formais mais antigos para as suas três sonatas de câmara, porém, ainda verdadeiramente franceses - cabe ressaltar que em 1914 é deflagrada a Primeira Guerra Mundial, e Debussy adotava uma posição nacionalista fervorosa, assinando as três sonatas pela primeira vez como "Claude Debussy - musicien français". Tendo adquirido grande conhecimento da obra de Rameau por ter editado sua ópera Les fêtes de Polymnie, publicada em 1908, Debussy mostra-se nas sonatas de câmara fortemente influenciado por compositores do Barroco francês, principalmente por Couperin e Rameau, músicos que "proporcionavam a Debussy um elo com uma tradição puramente francesa que era símbolo de clareza, sutileza, inteligência e nuance e servia de antídoto ao peso excessivo, pompa e magnificência" (WHEELDON, 2005, p.669).

\section{Forma sonata na Sonata para flauta, viola e harpa}

Na Sonata pra flauta, viola e harpa, é notável o fato de que alguns aspectos estruturais pertencentes ao tonalismo são mais claros do que os presentes no Quarteto de cordas em sol menor. A forma sonata é um exemplo disso. É possível observar que a exposição da Sonata é composta por duas partes, a e b (Figura 31), cada uma com dois temas formados por antecedentes e consequentes. Diferentemente do Quarteto, encontramos na reexposição da forma sonata um retorno de quase todos os elementos presentes na exposição; o único elemento que não é reapresentado é o a' da parte a. Assim, é possível afirmar que na Sonata para flauta, viola e harpa, a forma sonata encontra-se presente de maneira mais clara do que no Quarteto de cordas em sol menor.

Paradoxalmente, encontramos aliada à clareza formal uma liberdade maior na maneira como o compositor utiliza a forma sonata na Sonata para flauta, viola e harpa. Mesmo sendo sua exposição mais convencional do que a do Quarteto e tendo sua recapitulação um retorno de quase todos os seus elementos, encontramos os temas expostos na terceira seção formal em uma ordem diferente da original: primeiramente é apresentado o tema $\mathbf{b}$, e na sequência a transição e o tema $\mathbf{a}$, invertendo a ordem inicial destes. Tal fato proporciona maior suavidade ao retorno dos temas, pois a expectativa de retorno do primeiro tema é amenizada pelo retorno de um tema "secundário". Além disso, é criada uma estrutura simétrica em larga escala na disposição dos temas apresentados, com o eixo de simetria presente na metade do desenvolvimento. 


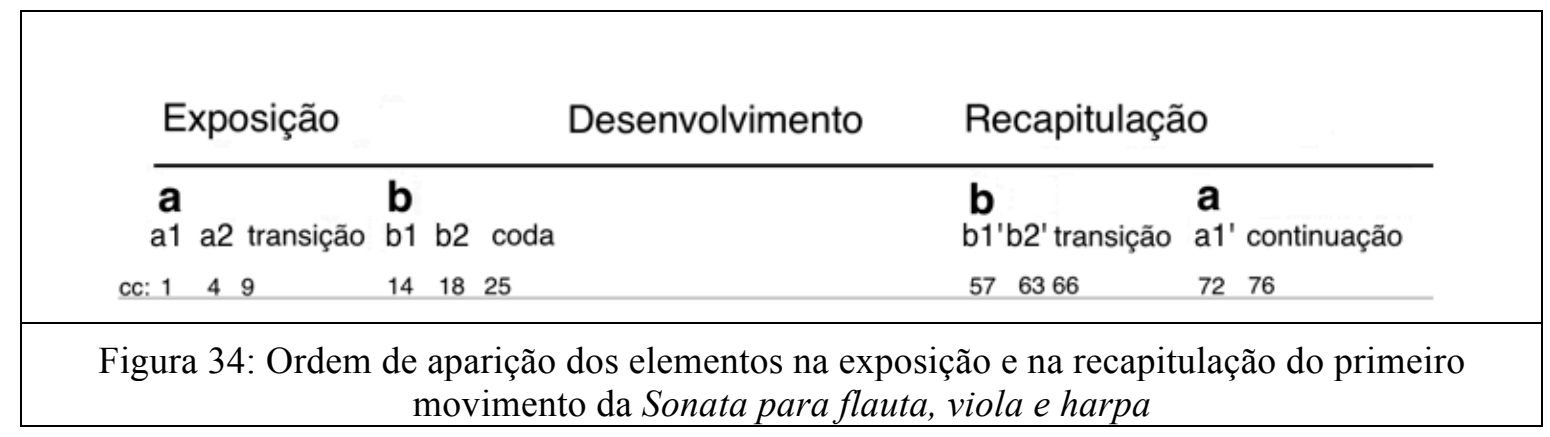

Tais peculiaridades da forma sonata desta peça fazem com que ela se relacione com o Quarteto de forma interessante: se no início da carreira de Debussy observamos uma utilização estrita deste modelo formal corrompido, como ele costuma ser visto ao final do século XIX, no final de sua carreira encontramos justamente o oposto: uma utilização mais livre de um modelo formal mais nítido e fora de seu tempo. Tal diferença faz jus à maturidade composicional presente em cada uma das peças.

\section{Apresentações temáticas: comparação entre o Quarteto e a Sonata}

A primeira observação que pode ser feita com relação às apresentações temáticas da Sonata para flauta, viola e harpa é o fato de que existe uma diferença significativa na quantidade de apresentações de temas em relação a esta peça e o Quarteto. Trata-se de 22 apresentações temáticas no primeiro movimento do Quarteto frente a 13 apresentações temáticas no primeiro movimento da Sonata $^{27}$. Tal fato pode ser explicado pela proximidade do Quarteto a obras do final do século XIX, influenciadas por elementos como leitmotiv ${ }^{28}$, em que uma profusão de temas com inúmeras distorções é apresentada (o quarteto de cordas de César Franck é um bom exemplo deste tipo de procedimento, pois nele também observamos uma grande quantidade de apresentações temáticas). A figura a seguir deixa claro que, sob este aspecto, a principal diferença encontra-se na quantidade de temas diferentes presentes na segunda seção formal de ambas: enquanto na Sonata encontramos poucas repetições temáticas, o

27 Ainda que a Sonata para flauta, viola e harpa tenha 84 compassos e o Quarteto de cordas em sol menor tenha 194 compassos, a primeira é de uma peça lenta, em 9/8, enquanto a segunda é rápida em 4/4. Em diferentes gravações, suas durações são bastante próximas, o que faz com que comparações entre as duas peças sejam válidas.

28 Importante mencionar que no período de composição do Quarteto, Debussy era um admirador devoto de obras de Richard Wagner, tendo ido por duas vezes a Bayreuth para assistir suas obras. Sobre a influência de Wagner em Debussy, ver o livro Neoclassicism in Music (MESSING, 1988). 
desenvolvimento do Quarteto é marcado por uma grande quantidade de repetições de um mesmo tema.

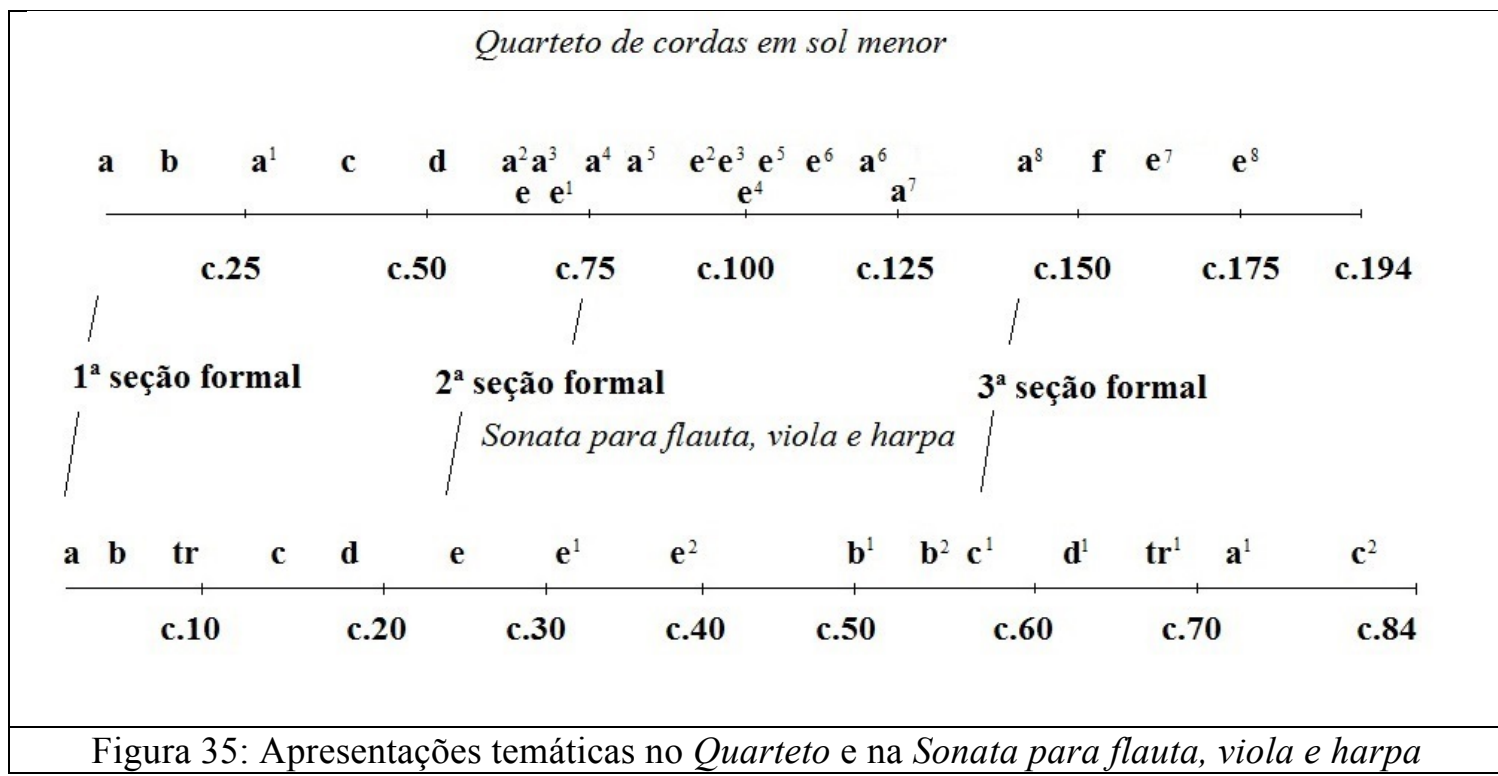

$\mathrm{Na}$ forma de manipulação dos temas das duas peças também há similaridades: assim como no Quarteto, a Sonata também possui dois gestos que são base para todo o desenvolvimento melódico da peça. Porém, se encontramos no Quarteto aquilo que Parks denominava "temas morfológicos", ou seja, melodias de alguns compassos sofrendo um desenvolvimento temático, o que se identifica de semelhança entre unidades melódicas na Sonata dificilmente pode ser chamado de tema: trata-se essencialmente de gestos, de três ou quatro notas que sofrem as mais variadas manipulações. Na figura seguinte encontram-se os dois principais gestos do primeiro movimento.

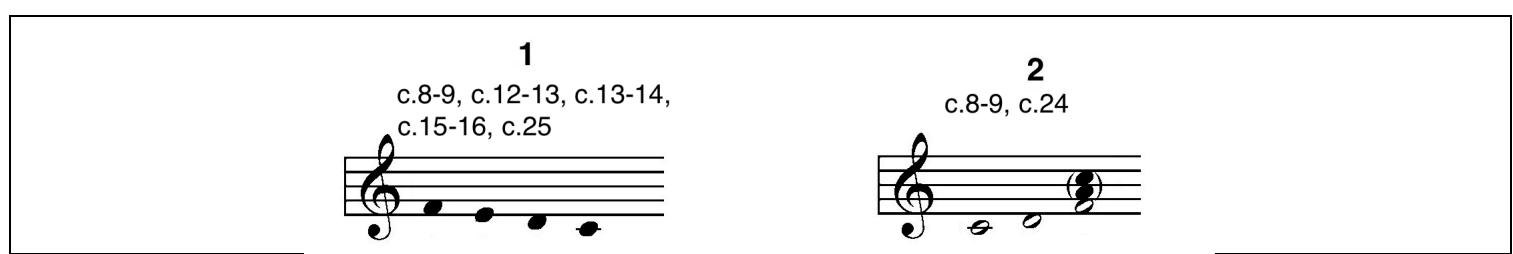

Figura 36: Dois importantes gestos do primeiro movimento da Sonata para flauta, viola e harpa

É evidente que se tratando de materiais motívicos reduzidos, a quantidade de manipulação que este material sofre é significativamente maior. Encontramos nesta peça diversos exemplos de inversões, transposições, reordenações e distorções 
intervalares destes dois gestos. Um importante exemplo de interação entre os dois é o material melódico presente no desenvolvimento, que mostra de que maneira Debussy é capaz de integrar os dois gestos da figura seguinte.

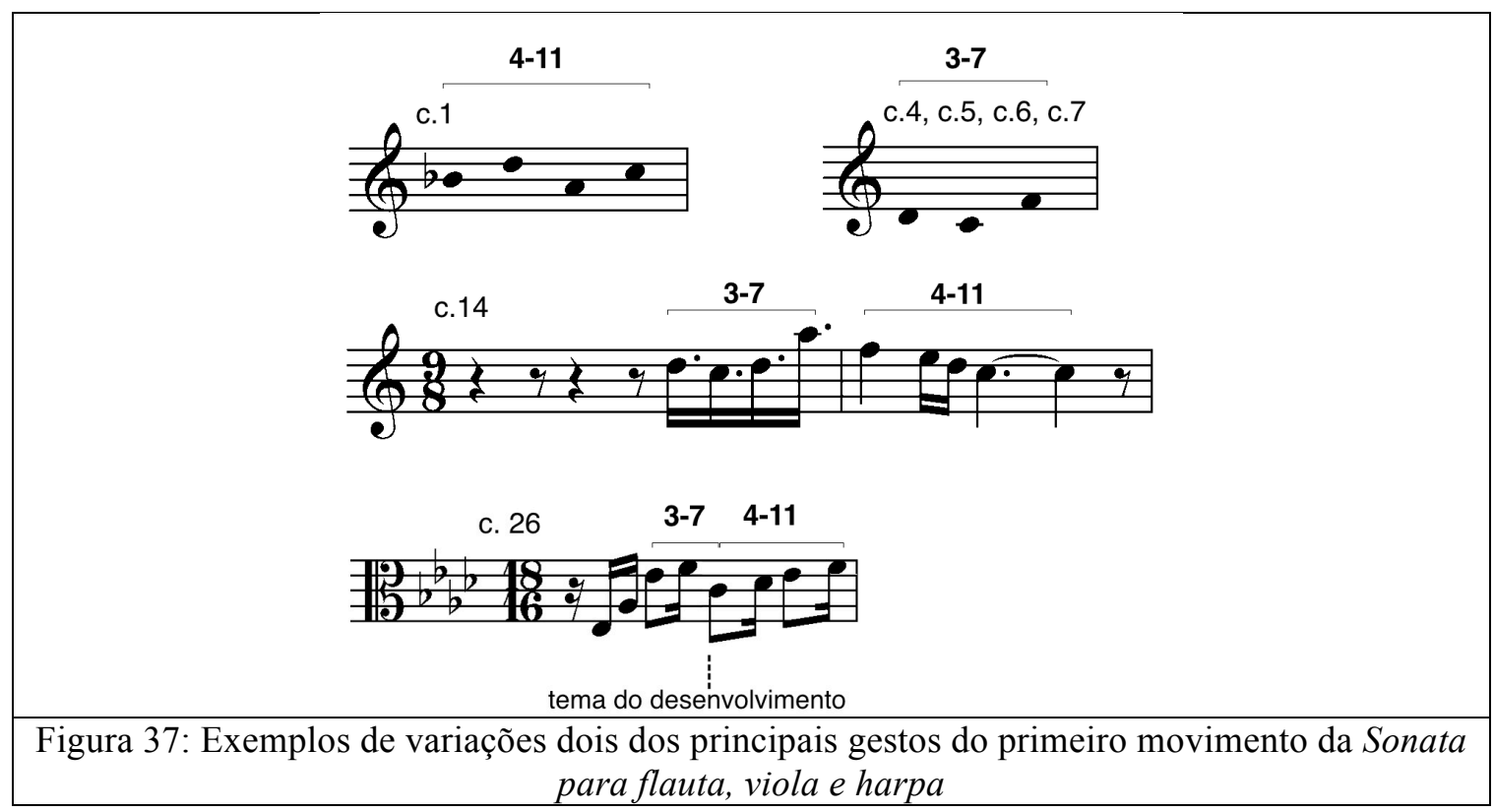

A redução no tamanho das unidades motívicas aproxima a Sonata ao balé sinfônico Jeux, obra a cujo respeito comentários de Eimert foram observados no capítulo anterior. Porém, é interessante ressaltar que, se em Jeux não é possível identificar a presença do elementos tonais, estes se encontram em grande escala nesta Sonata. Esta pode ser uma das razões pela qual Jeux utiliza uma quantidade de elementos motívicos muito maior; a falta de um elemento com potencial estruturante como técnicas advindas do tonalismo poderia criar a necessidade de utilização de mais elementos motívicos. A figura a seguir demonstra a ordem de apresentação dos 24 elementos motívicos de Jeux identificados por Eimert.

\section{$A-\mathrm{B}-\mathrm{C}-\boldsymbol{A}-\mathrm{D}-\mathrm{E}-\mathrm{A}-\mathrm{E}-\mathrm{F}-\mathrm{D}-\mathrm{G}-\mathrm{H}-\mathrm{D}-\mathrm{G}-\mathrm{H}-\mathrm{I}-\mathrm{H}-\mathrm{I}-\mathrm{F}-\mathrm{H}-\mathrm{K}-\mathrm{H}-\mathrm{F}-\mathrm{K}-$ $\mathrm{L}-\mathrm{M}-\mathrm{L}-\mathrm{N}-\mathrm{O}-\mathrm{N}-\boldsymbol{A}-\mathrm{P}-\mathrm{Q}-\mathrm{P}-\mathrm{Q}-\mathrm{R}-\mathrm{S}-\mathrm{T}-\mathrm{U}-\mathrm{A}-\mathrm{U}-\mathrm{A}-\mathrm{V}-\mathrm{W}-\mathrm{X}-\mathrm{A}-\mathrm{X}-\mathrm{A}-\mathrm{X}$}

Figura 38: Ordem de apresentação dos materiais motívicos em Jeux; as letras "A" sublinhadas significam reapresentações literais; as não sublinhadas significam que apenas trechos são reapresentados (EIMERT, 1959, p.7)

É interessante observar que, neste sentido, os primeiros movimentos do Quarteto e da Sonata aproximam-se (e se distanciam de Jeux): ambos possuem cinco elementos 
temáticos (ou motívicos), apesar de o Quarteto apresentar mais repetições destes elementos. Tal fato sugere que pode existir uma relação entre estes dois elementos: a quantidade de motivos ou temas torna-se significativamente reduzida quando existe a presença de diferentes elementos pertencentes ao tonalismo, sejam eles de ordem harmônica ou formal.

\section{Simetria em um plano formal em larga escala na Sonata para flauta, viola e harpa}

Por ser uma obra caracterizada pela presença de tríades e tétrades, também é importante investigar de que maneira elementos harmônicos contribuem para a coerência formal do primeiro movimento da Sonata. No artigo Tonal Allusion and Illusion: Debussy's Sonata for Flute, Viola and Harp (ALLEN, 1983) é apresentada uma redução harmônica da peça a partir da qual é possível deduzir alguns princípios de coerência.

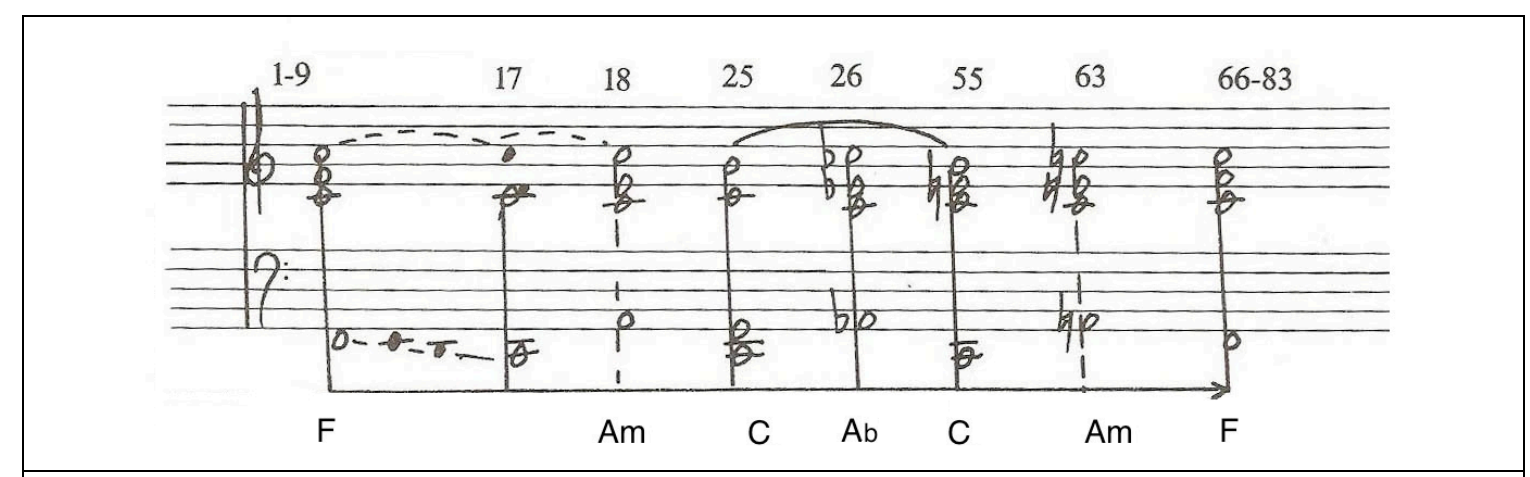

Figura 39: Redução harmônica da Sonata para flauta, viola e harpa (ALLEN, 1983, p.40)

Podemos observar um mesmo padrão harmônico presente não apenas em diferentes localidades, mas também em planos formais distintos; em um plano formal intermediário, com unidades de sete a dez compassos, observamos que existe uma alternância entre os acordes do I, III e V graus do campo harmônico de fá maior (c.9, c. 18 , c. 25 e c.55, c.63, c.83). Também é possível identificar uma alternância entre o I, III e V graus do campo harmônico de fá menor em um plano formal em larga escala (c.9, c. 26, c.55).

Esses três gestos demonstram que existe nesta peça um pensamento harmônico carregado de direcionalidade, pois a peça parte da tônica, chega a sua dominante e retorna à tônica, apresentando o mesmo gesto em diferentes localidades. Desta forma, 
fica evidente uma estrutura que reforça a simetria presente na forma sonata da peça não apenas pela inversão dos graus I, III e $\mathrm{V}$ em um plano formal intermediário, mas também por uma projeção do mesmo gesto (em outro modo, algo bastante recorrente nesta peça) em um plano formal em larga escala.

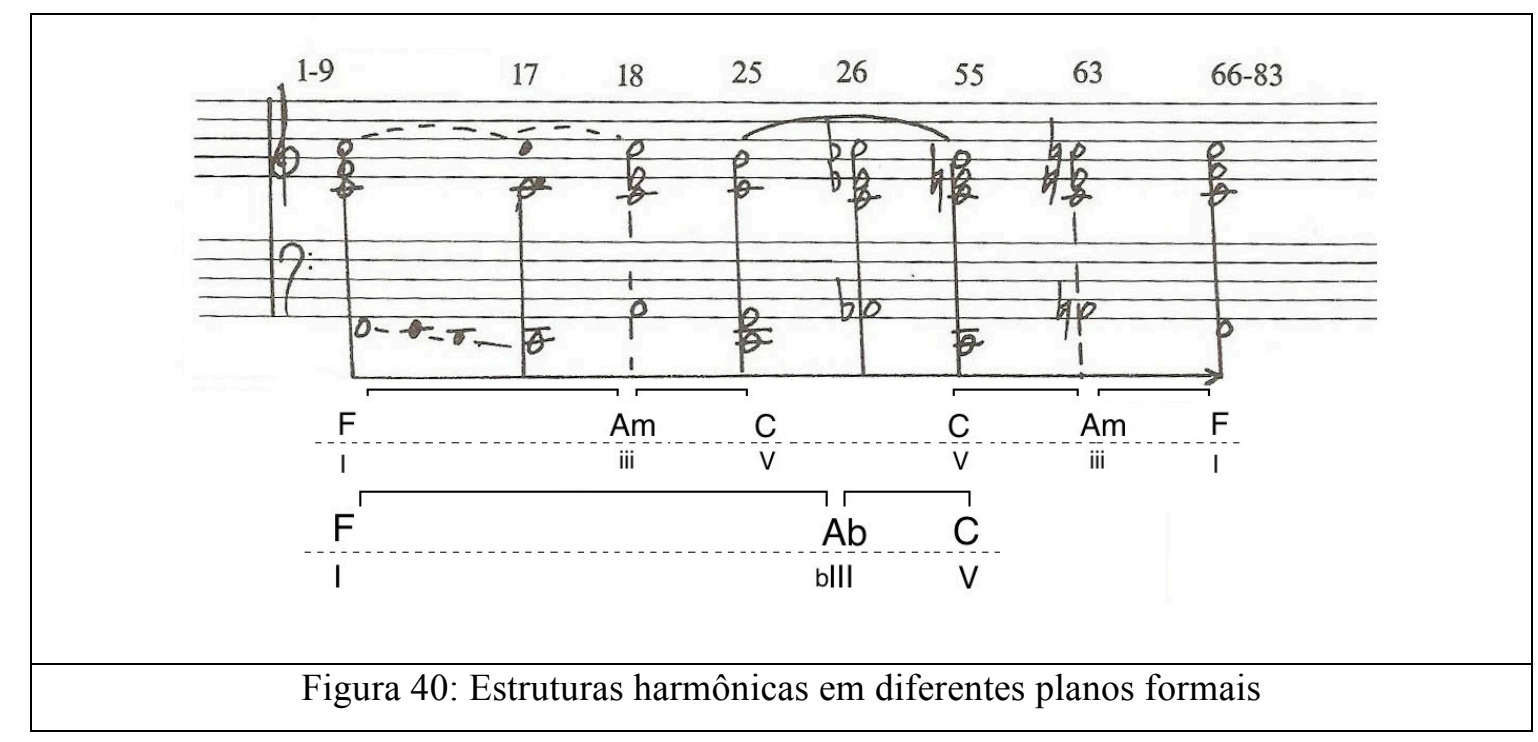




\section{Conclusão}

Como foi mencionado na introdução, este trabalho não tem como objetivo realizar uma análise explicando todos os níveis de coerência ou unidade presentes no Quarteto de cordas em sol menor de Debussy. Buscou-se, aqui, apresentar trechos do primeiro movimento nos quais fosse possível colocar em prática diferentes conceitos teóricos observados. Desta forma, além de integrar conceitos analíticos de diversos autores, também foi possível chegar a algumas conclusões que se encontram aqui aliadas a uma breve retrospectiva das principais questões abordadas no trabalho.

\section{Uma mudança na compreensão analítica da música de Claude Debussy ao} longo dos séculos XX e XXI

- Primeira metade do século XX: pouco tempo para compreender as mudanças trazidas pela música de Debussy, apego a questões tradicionalistas, incompreensão dos procedimentos formais e aspectos revolucionários do compositor.

- Segunda metade do século XX: Eimert soluciona importantes questões formais em Jeux, buscando compreender de que maneira a forma é construída nesta peça. Ligado à vanguarda de sua época, Eimert pensa na música de Debussy de forma quase serial, colocando pequenos motivos como elementos formais de destaque, ao lado do timbre e de movimentos de ondulações. Parks aplica algumas das principais metodologias analíticas desenvolvidas ao longo desse período (gráficos prolongacionais e teoria dos conjuntos) à música de Debussy, mostrando que cada uma contribui de uma maneira para sua compreensão, ainda que nenhuma delas seja suficiente para explicar a música de Debussy sozinha. Yih aprofunda-se sobre essas duas metodologias, porém sua principal contribuição encontra-se no resgate do motivo como força estrutural, já observado por Eimert em Jeux, mas menos presente em Parks.

- Século XXI: Wheeldon resgata um conceito tradicional de forma, a forma cíclica, para encontrar unidade em um plano formal em larga escala no Quarteto, apontando Debussy como um renovador deste conceito, pois nele a forma cíclica utiliza o timbre como elemento cíclico. Bourion distancia-se de elementos tradicionalmente pesquisados em análise musical (harmonia, melodia e forma), 
buscando compreender características da música de Debussy por meio de seu uso da repetição dentro da música. A simetria presente em um plano formal reduzido, observada em diversas reiterações no Quarteto, é um elemento que tem potencial para ligar os conceitos de Bourion a diferentes características formais presentes em planos formais em larga escala.

\section{Uma dicotomia a partir de dois conceitos de forma e o uso de reiterações no} Quarteto

As noções de forma morfológica e forma cinética são apresentadas no livro The Music of Claude Debussy de Richard Parks. Sua diferenciação é importante, pois estabelece a distinção entre duas maneiras opostas de obter continuidade. A forma morfológica é aquela na qual identificamos elementos formais tradicionais (mudanças de frases, períodos, seções etc.). Nela, a continuidade é obtida pela semelhança entre elementos de diferentes partes da música (melódicos, harmônicos ou mesmo texturais). Já a forma cinética é encontrada quando se identificam diferenças entre duas ou mais partes que são capazes de estabelecer um padrão, articulando alguma espécie de coerência entre essas partes. Estando a forma morfológica do Quarteto já identificada por Parks, esta pesquisa identificou alguns exemplos de forma cinética em diferentes planos formais com o objetivo de apontar alguns elementos que atuam na sensação de movimento ou direcionalidade da peça:

- Cc.1-60. No trecho, foram identificadas duas características relacionadas à forma cinética: uma alternância regular entre dois tipos de textura, $\mathbf{A}$ e $\mathbf{B}$, que cria uma periodicidade em um plano médio e uma progressiva diminuição na similaridade dos temas observados com relação ao tema inicial, o que cria um movimento linear, direcional. É interessante observar que os dois tipos de processos cinéticos atuam em um mesmo plano formal, demonstrando que o objetivo de Debussy neste trecho não é criar um movimento unidirecional sob este aspecto, e sim criar uma complexidade que enriquece a percepção do trecho.

- Cc.88-112. Também é possível localizar um exemplo de forma cinética periódica em um plano formal médio neste trecho, pois existe uma alternância entre apresentações melódica com características diatônicas/tons inteiros e apresentações cromáticas. Aqui, o elemento direcional fica a cargo 
da harmonia, que se torna progressivamente mais complexa a cada exposição temática.

- Cc.25, cc.113-119, cc.136-137. Nos três trechos, foi observada uma interessante relação entre aspectos reiterados e aspectos originais em um plano formal reduzido. Neles encontramos perfis melódicos que aparentam possuir certa linearidade mas que possuem, camuflada, uma grande incidência de reiterações, principalmente sob o âmbito harmônico. Mais uma vez, elementos periódicos e direcionais encontram-se fortemente imbricados (porém, aqui, em um plano formal reduzido). Em finais de unidades formais, também é possível encontrar uma forte incidência de elementos simétricos em pequena escala, tanto em elementos texturais e contorno melódico, quanto no uso de reiterações.

- Cc.119-130. O exemplo mais abstrato, mais distante da audição, da forma cinética periódica encontra-se em uma espécie de bordadura localizada no conjunto de classes de altura deste trecho, em que ocorre uma alternância entre $\mathbf{A} \mathbf{B}$ e $\mathbf{B} \mathbf{A}$, semelhante ao que é observado em um plano formal reduzido no trecho anterior, cc.113-118.

A partir desses exemplos observados, pretende-se demonstrar a grande sofisticação de Debussy no uso de elementos reiterados, com uma manipulação consciente destes materiais que faz com que eles possuam importância estrutural na peça. Tal característica influencia diretamente a sensação de movimento da peça, relacionando assim o uso de elementos reiterados e a forma cíclica.

\section{Análise paradigmática}

Este modelo de análise, proposto por Bourion, é utilizado aqui para observarmos de que maneira se comporta o padrão de mudanças texturais da peça. Com ele é possível chegar a duas conclusões: a primeira é que é válida uma divisão formal em três seções do movimento, pois as mudanças texturais da peça alteram seus padrões de comportamento respeitando estas mudanças de seção. A segunda é que, mesmo existindo de fato três seções formais, existe pouca semelhança entre a primeira e a terceira seções formais, o que distancia a peça de uma forma sonata convencional. Esta característica torna interessante uma comparação entre o Quarteto de cordas em sol menor e a Sonata para flauta, viola e harpa, duas peças com importantes elementos formais em comum. 


\section{O Quarteto em sol menor e a Sonata para flauta, viola e harpa}

Assim como o Quarteto, a Sonata para flauta, viola e harpa é uma peça para música de câmara composta utilizando procedimentos cíclicos e com a presença de importantes elementos advindos da tradição tonal. A peça foi composta entre 19151916, o que faz com que uma comparação entre as duas se torne especialmente interessante para observar de que maneira procedimentos composicionais semelhantes atuam em períodos distintos. Aqui, chegou-se às seguintes conclusões:

- A forma cíclica da Sonata não se encontra ligada ao compositor César Franck e ao fim do século XIX (o que ocorre com o Quarteto) e sim à tradição barroca francesa de Couperin e Rameau.

- Formalmente, a peça pode ser classificada como uma forma sonata; esta característica encontra-se em maior evidencia do que no Quarteto, pois na terceira seção formal encontramos boa parte dos elementos presentes na primeira seção formal, porém com sua ordem invertida.

- Tanto o Quarteto quanto a Sonata possuem cinco elementos melódicos em seu primeiro movimento. Porém, no Quarteto encontramos maior quantidade de repetições destes elementos melódicos, especialmente na segunda seção formal.

- Na Sonata, o tamanho destes elementos melódicos é significativamente reduzido, o que a aproxima do balé sinfônico Jeux, composto poucos anos antes. Estes fragmentos melódicos sofrem mais manipulações e distorções do que temas como os do Quarteto.

- Sob um plano harmônico, é possível localizar gestos semelhantes, presentes em diferentes planos formais: a ênfase nos acordes pertencentes ao I, III e V graus do campo harmônico de fá (maior e menor, lembrando que a mudança da terça ao longo da peça é algo recorrente em Debussy). Esta característica cria dois elementos importantes em um plano formal em larga escala: o primeiro é uma sensação de retorno suavizada, pois o primeiro elemento melódico só retorna após a apresentação dos outros, que têm menos força estrutural. $\mathrm{O}$ segundo é que aspectos simétricos se tornam evidentes por meio de uma simetria em um plano formal intermediário, com um espelhamento do gesto I, III, V com um eixo vertical na metade do 
desenvolvimento. Também foi observada uma projeção deste mesmo gesto em diferentes planos formais, em média e larga escala, colaborando para a coerência total da peça.

Com base nessas características, é possível levantar uma hipótese sobre comportamentos composicionais observados a partir da comparação entre estas duas peças $^{29}$.

Um processo semelhante ao identificado por Bourion em reiterações e reapresentações parece existir com relação a simetrias em Debussy. A autora defende que, no início de sua carreira, Debussy utilizava repetições em um plano formal em larga escala, com seções formais inteiras sendo repetidas. Ao final de sua carreira, as repetições encontram-se em um plano formal reduzido, sendo as seções formais maiores mais lineares, menos repetidas.

Um procedimento análogo é sugerido por este trabalho com relação às simetrias. No início de sua carreira, com o Quarteto de cordas em sol menor, identificamos a presença de elementos simétricos em um plano formal reduzido, especialmente ao final de unidades formais. Na Sonata para flauta, viola e harpa, foi possível identificar elementos simétricos em um plano formal em larga escala, por meio de características harmônicas e aspectos formais pertencentes à tradição tonal.

Conceitualmente, é possível compreender o comportamento observado acima como semelhante ao que ocorre em elementos da forma cinética, pois é possível identificar um padrão nestas mudanças entre as duas peças, uma direcionalidade que, dentro da ideia de forma cinética, é responsável por uma sensação de movimento. Se observamos dentro do Quarteto processos cinéticos como a diminuição de similaridade temática com relação ao primeiro tema, é possível conceber a diminuição no tamanho das unidades reiteradas ao longo de toda a carreira de Debussy (como aponta Bourion), ou a observação de aspectos simétricos em um plano formal em larga escala no final de sua carreira (hipótese levantada por esta pesquisa) como espécies de processos cinéticos, lineares, presentes em um plano formal em uma escala ainda maior, neste caso, toda a carreira de Debussy.

É evidente que estes exemplos são apenas hipóteses, sendo necessárias análises de outras peças do compositor para que se possa afirmar que tais padrões são, de fato,

29 Para que esta hipótese se tornasse uma conclusão, seria necessário observar outras peças de diferentes períodos, confirmando que o que foi observado nesta pesquisa de fato se aplica de forma generalizada à música de Debussy ou a um período específico de sua carreira. 
observados no compositor, porém é uma forma de conceber uma análise musical enriquecedora, pois diminui a distância entre elementos analíticos de diferentes planos. Por mais que as implicações analíticas de cada aspecto sejam diferentes, parece-nos interessante investigar se é possível traçar relações entre linearidades em diferentes planos, ultrapassando limites convencionalmente estabelecidos e investigando também o que pode ser revelado ao conceber a obra de Debussy como uma espécie de plano formal macrodimensional em larguíssima escala. 


\section{Bibliografia}

ABRAMOVAY, Juliano. Direcionalidade na composição da Sonata para flauta, viola e harpa de Claude Debussy. In: Anais do XXI congresso da Anppom, Uberlândia, 2011.

ADORNO, Theodor W. Philosofie de la nouvelle musique. Paris: Gallimard, 1962.

ALLEN, Judith Shatin. Tonal Allusion and Illusion: Debussy's Sonata for Flute, Viola and harp. In: Cahiers Debussy - Nouvelle série n.7, 1983.

BENEDETTI, Danieli. Produção pianística de Claude Debussy durante a primeira guerra mundial. In: Anais do XV congresso da Anppom, Rio de Janeiro, 2005.

BOULEZ, Pierre. Apontamentos de aprendiz. São Paulo: Perspectiva, [1958] 1995.

BOURION, Sylveline. Le Style de Claude Debussy: duplication, répetition et dualité dans les stratégies de composition. Paris: Vrin, 2011.

DAVIE, Cedric T. Musical Structure and Design. New York: Dover, 1966.

EIMERT, Herbert. “Debussy's 'Jeux””. Die Reihe n.5 (1959, versão inglesa, 1961), pp. $3-20$.

FERRAZ, Silvio. Música e repetição: aspectos da diferença na música do séc. XX. São Paulo: Educ/Fapesp, 1998.

FORTE, Allen. The Structure of Atonal Music. Yale: Yale University Press, 1973.

GUIGUE, Didier. Estética da sonoridade. São Paulo: Perspectiva, 2011.

LOCKSPEISER, Edward. Debussy. London: J. M. Dent and Sons, 1936.

MACDONALD, HUGH. Cyclic Form. In: SADIE, Stanley (Ed.). The New Grove Dictionary of Music and Musicians, v.6, 2.ed., New York: Oxford University Press, 2001, p.797-798. 
MASSIN, Jean \& Brigitte. A história da música ocidental. Rio de Janeiro: Nova Fronteira, 1997.

MESSING, Scott. Neoclassicism in Music: from the Genesis of the Concept through the Schoenberg/Stravinsky polemic. Michigan: UMI Research Press, 1988.

PARKS, Richard. The Music of Claude Debussy. New Haven and London: Yale University Press, 1989.

ROSEN, Charles. Sonata Forms. New York: Norton, 1988. . A geração romântica. São Paulo, Edusp, 2000.

SALLES, Paulo de Tarso. Villa-Lobos: processos composicionais. Campinas: Editora da Unicamp, 2009.

. Villa-Lobos: desafiando a teoria e análise. In: Anais do IV Encontro de musicologia de Ribeirão Preto, pp.81-95, 2012.

SCHOENBGERG, Arnold. Fundamentos da composição musical. São Paulo: Edusp, 2008 .

SOMER, Avo. Musical Syntax in the Sonatas of Debussy: Phrase Structure and Formal Function. In: Music Theory Spectrum, v.27, n.1, pp. 67-95, 2005.

STOÏANOVA, Ivanka. Manuel D’analyse Musical. Paris: Minerve, 2000.

STRAUS, Joseph N. Introduction to Post-Tonal Theory. New Jersey: Prentice Hall, 2004.

WEBSTER, James. Haydn's “Farewell” Symphony and the Idea of Classical Style:

Through-Composition and Cyclic Integration in his Instrumental Music. Cambridge:

Cambridge University Press, 1991.

WHEELDON, Marianne. Debussy and La Sonate cyclique. In: The Journal of Musicology, v.22, n.4, p.644-679, 2005. 
YIH, Annie. Analysing Debussy: Tonality, Motivic Sets and the Referential Pitch-Class Specific Collection. In: Music Analysis, v.19, n.2, p.203-229, 2000.

\section{Internet}

ENCICLOPEDIA BRITTANICA: Cyclic Form (definição). Disponível em: http://global.britannica.com/EBchecked/topic/147944/cyclic-form. Acessado em julho de 2014. 


\section{Apêndice}

Este apêndice é formado por uma tabela na qual se encontram condensadas as principais observações formais e pela partitura do primeiro movimento do Quarteto de cordas em sol menor de Claude Debussy na qual se encontram destacadas as reiterações.

Na partitura, colchetes abaixo do pentagrama representam elementos reiterados, e seus pares são indicados por ligaduras. Indicações no meio das ligaduras apontam diferentes tipos de transposição: TM (transposição mediatriz), T(x) (transposição, onde $x$ representa a quantidade de semitons). Letras em maiúsculas abaixo do colchete representam a técnica do martelo e bigorna descrita por Bourion, e letras em minúsculas abaixo do colchete identificam pares reiterados. Letras em minúsculas no topo do sistema indicam os temas apresentados ao longo do movimento (a, b, c, d, e, f).

\begin{tabular}{|c|c|c|}
\hline Compasso & Descrição & Seção Formal \\
\hline $1-12$ & Tema a & \multirow{5}{*}{$\begin{array}{l}\text { 1ª seção formal }^{\text {(exposição) }}\end{array}$} \\
\hline $13-25$ & Tema b & \\
\hline $26-38$ & Tema a (mudança harmônica) & \\
\hline $39-60$ & Tema c, d & \\
\hline $61-74$ & Coda (tema e) & \\
\hline $75-87$ & Tema a & \multirow{3}{*}{$\begin{array}{l}2^{\mathrm{a}} \text { seção formal } \\
\text { (desenvolvimento) }\end{array}$} \\
\hline $88-117$ & Tema e & \\
\hline $118-137$ & Tema a & \\
\hline $138-148$ & Tema a & \multirow{5}{*}{$\begin{array}{l}3^{\text {a }} \text { seção formal } \\
\text { (recapitulação) }\end{array}$} \\
\hline $149-160$ & Tema f & \\
\hline $161-170$ & Tema e & \\
\hline $171-182$ & Subida, preparação & \\
\hline $183-194$ & Descida em uníssono e pentatônica & \\
\hline
\end{tabular}




\section{Claude Debussy \\ QUARTET IN G MINOR, Op. 10 \\ I}

Animé et trìs decide $63-10$

1:r Violon

24 Violou

Alto

Violoncelle
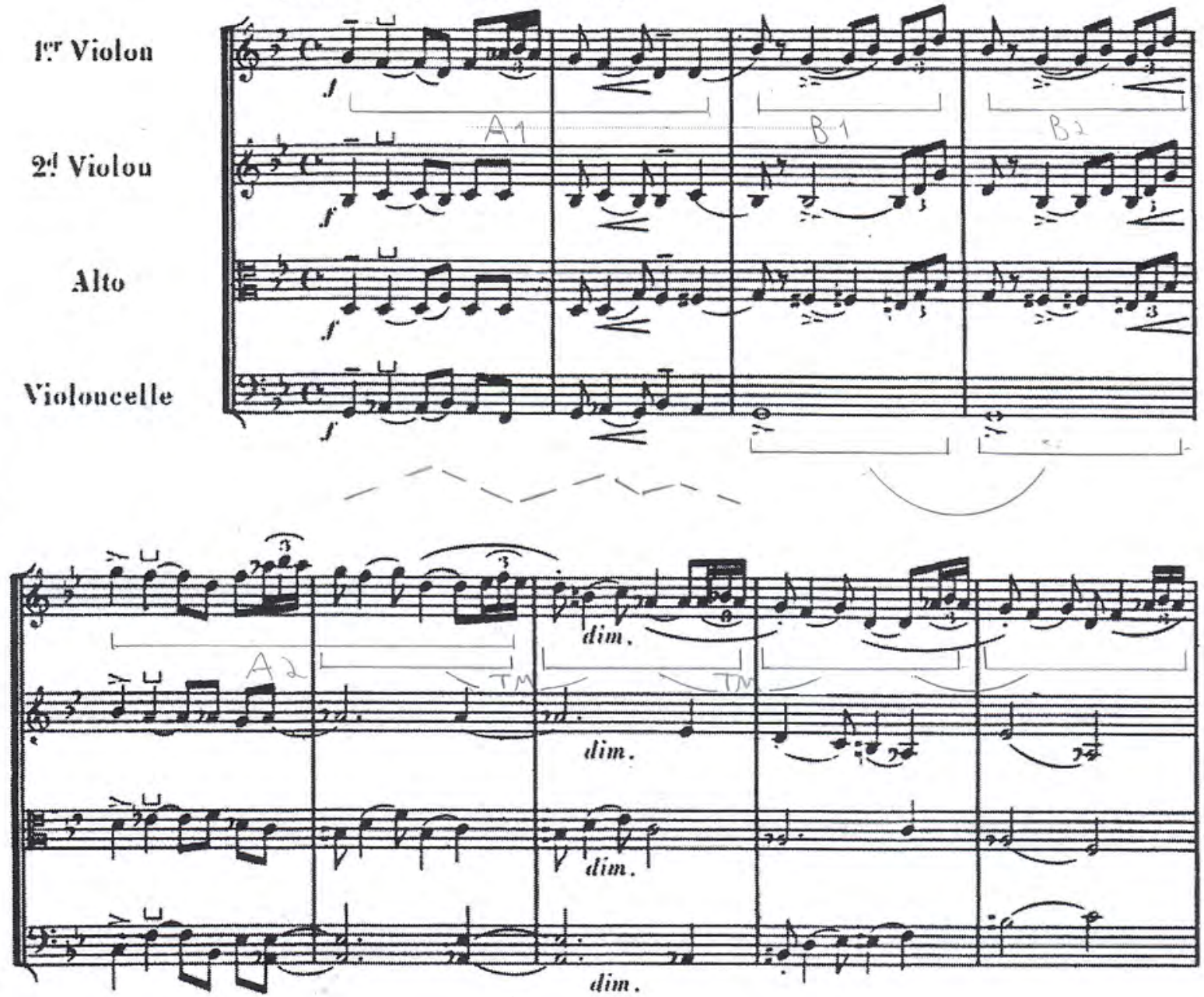

10

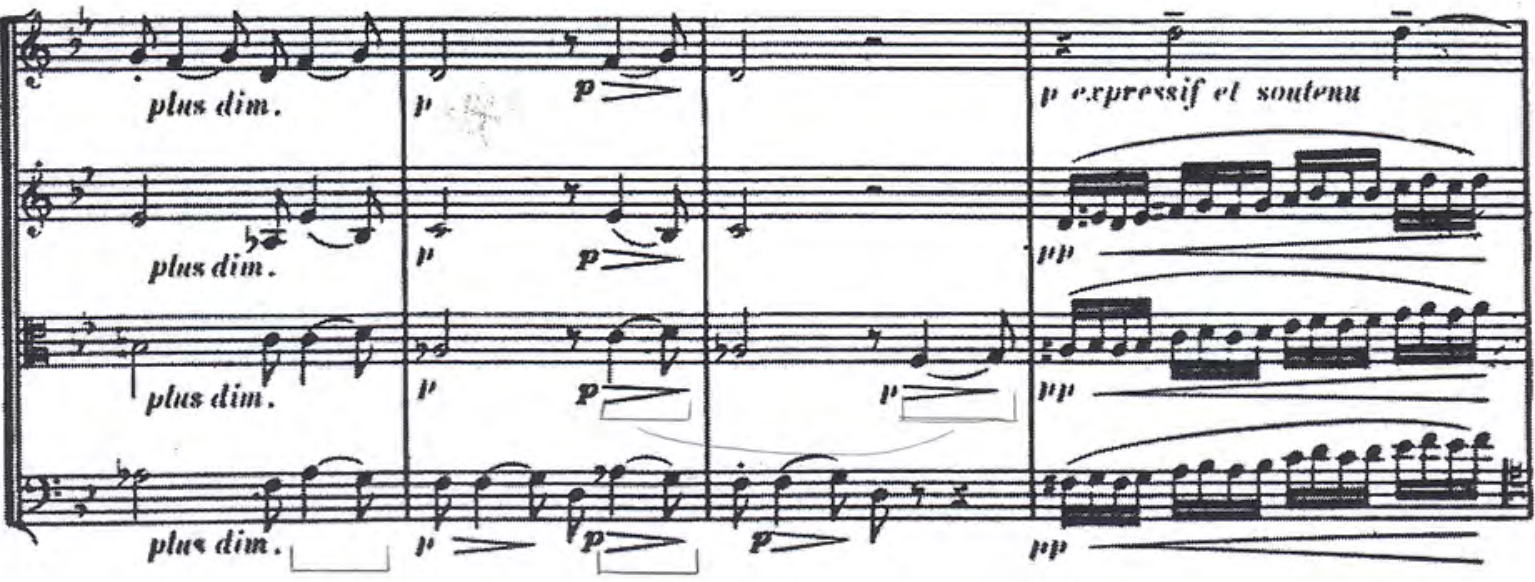




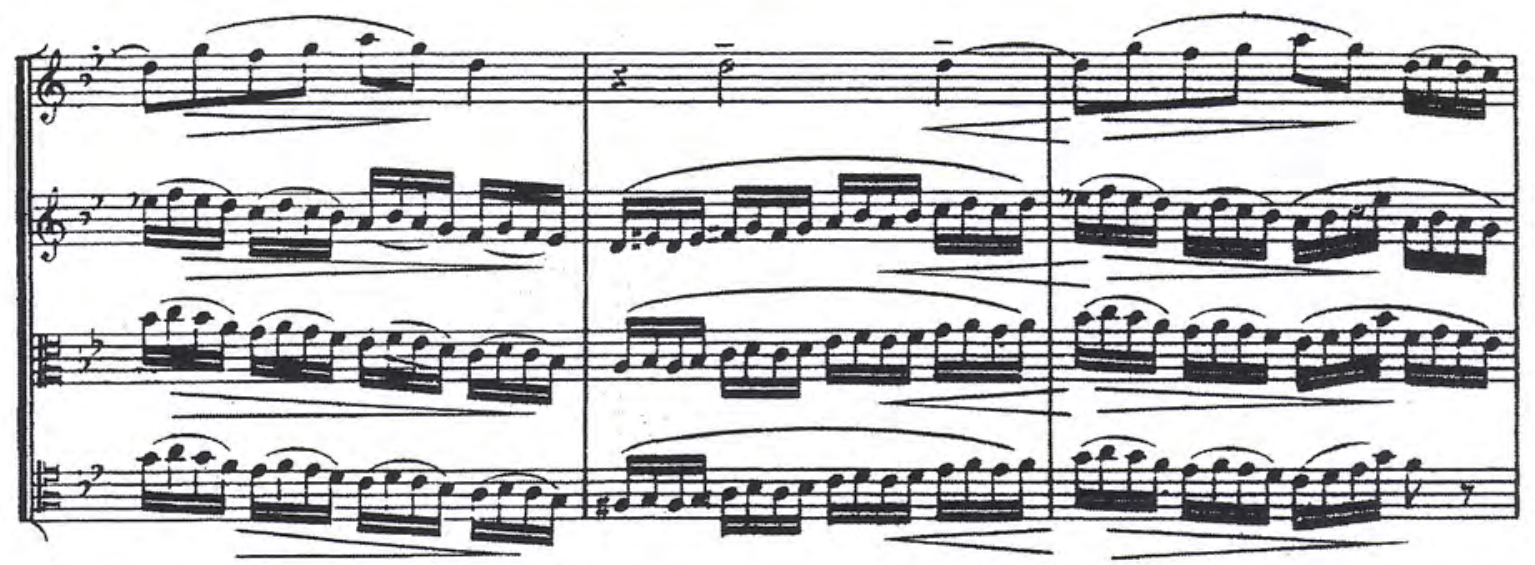

171 (1)
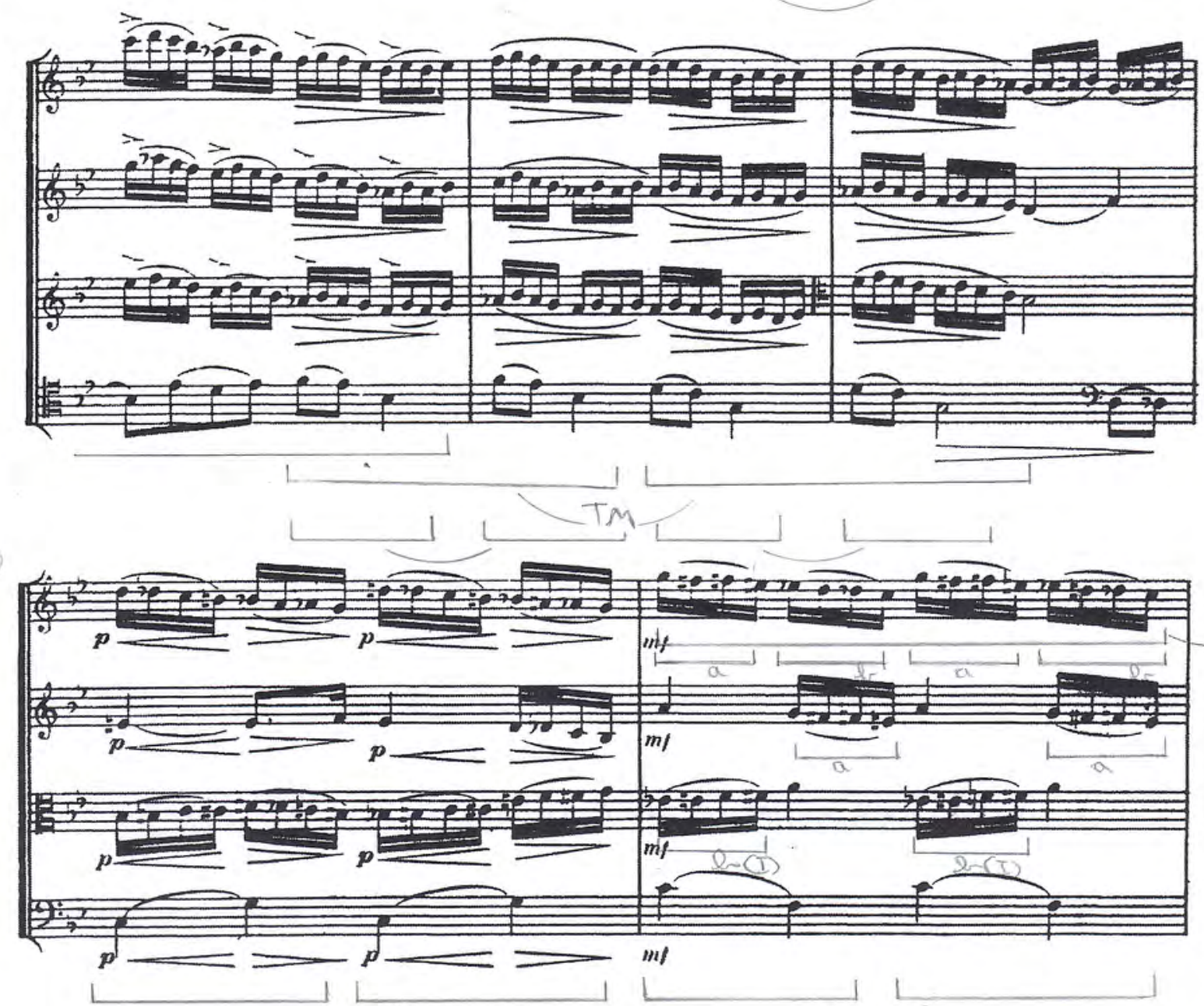
(1)
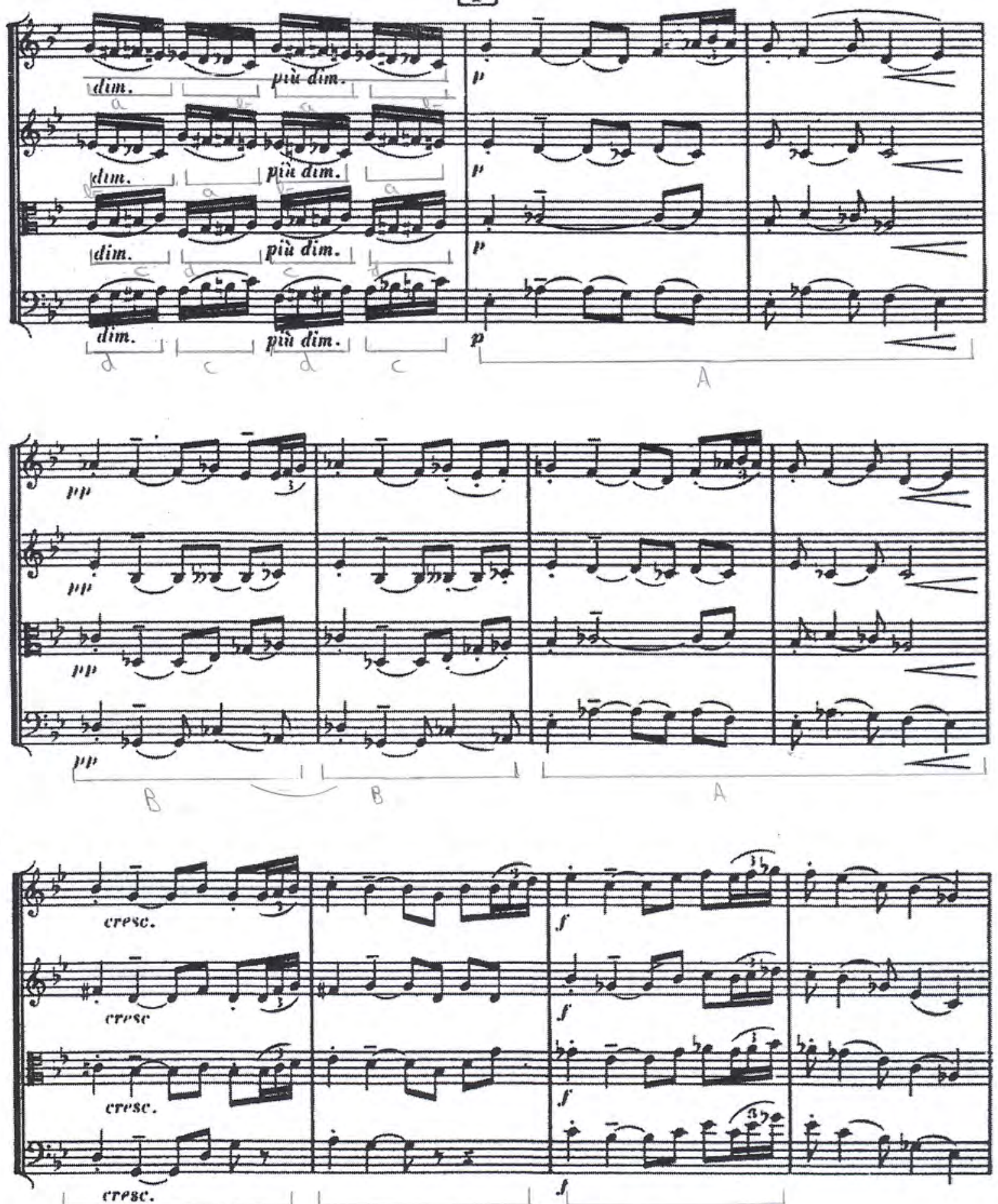

cresc.

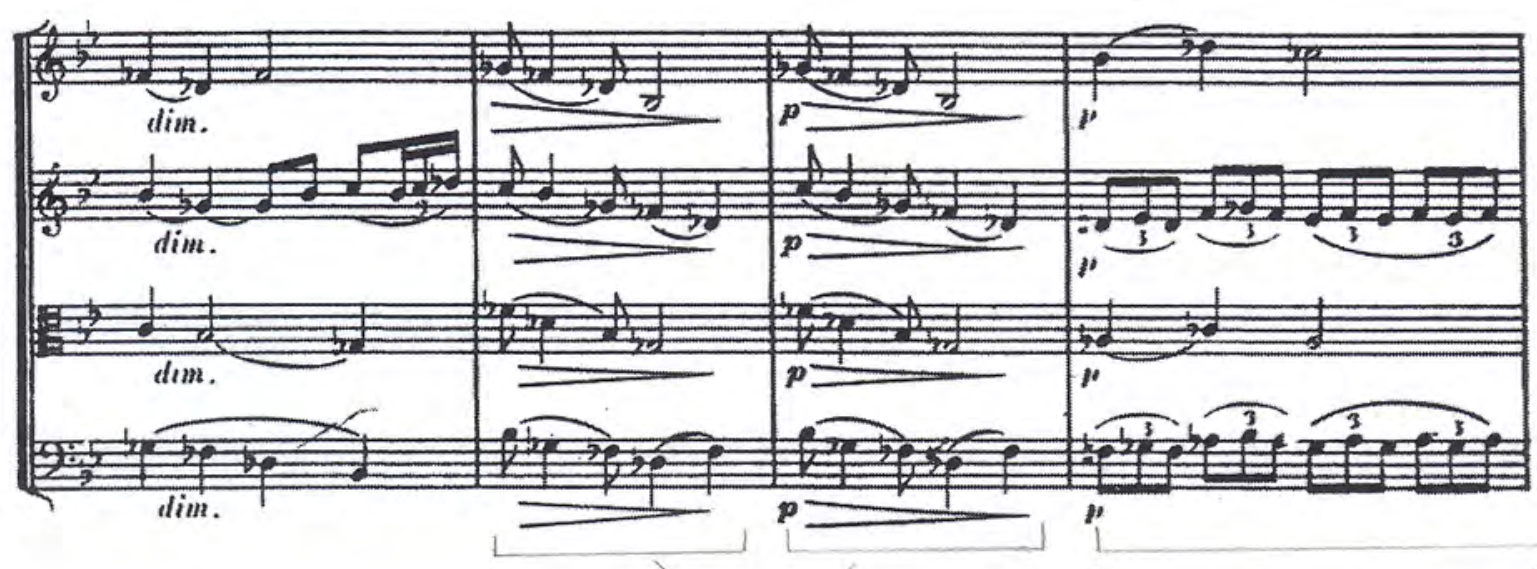



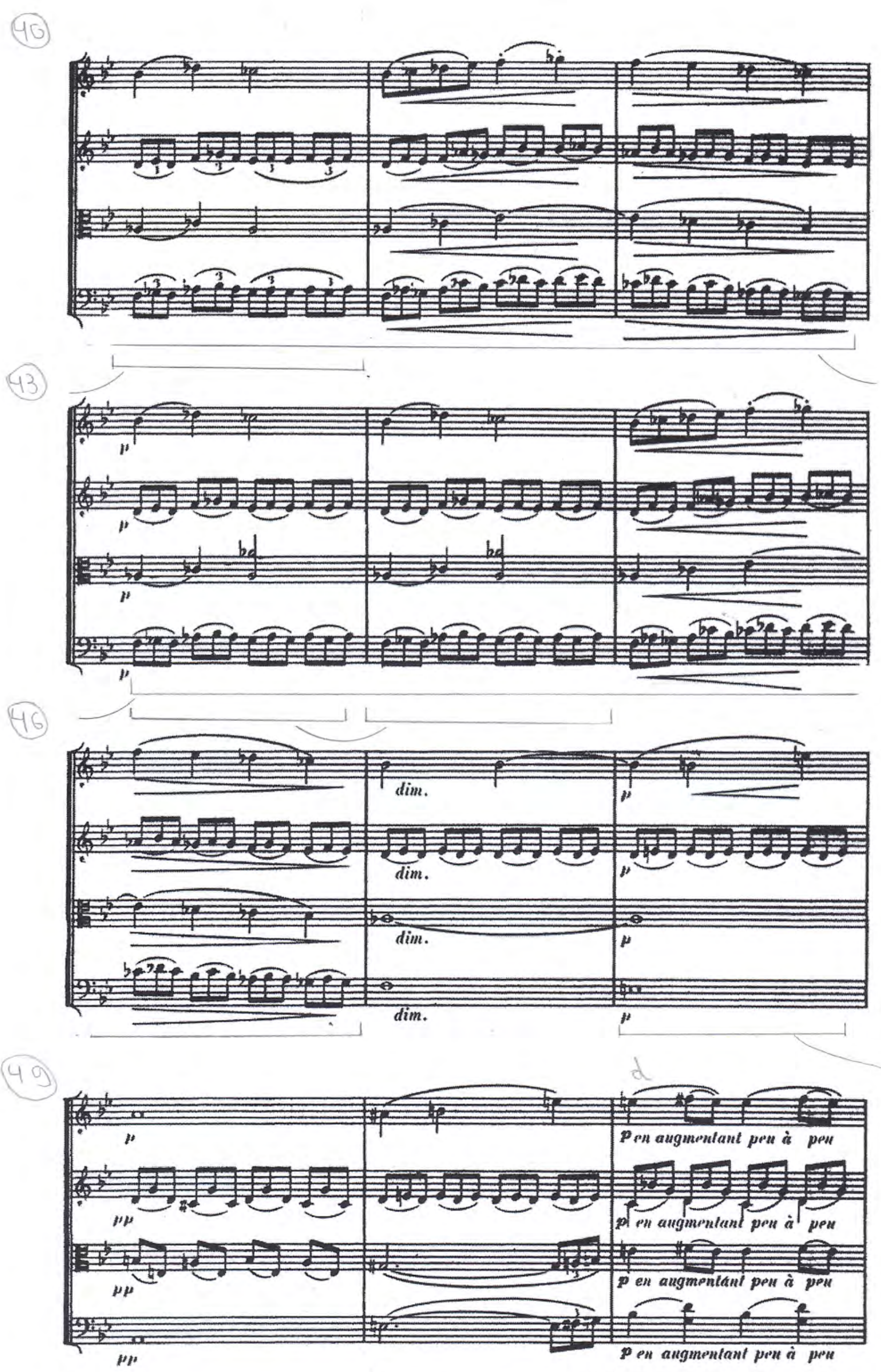

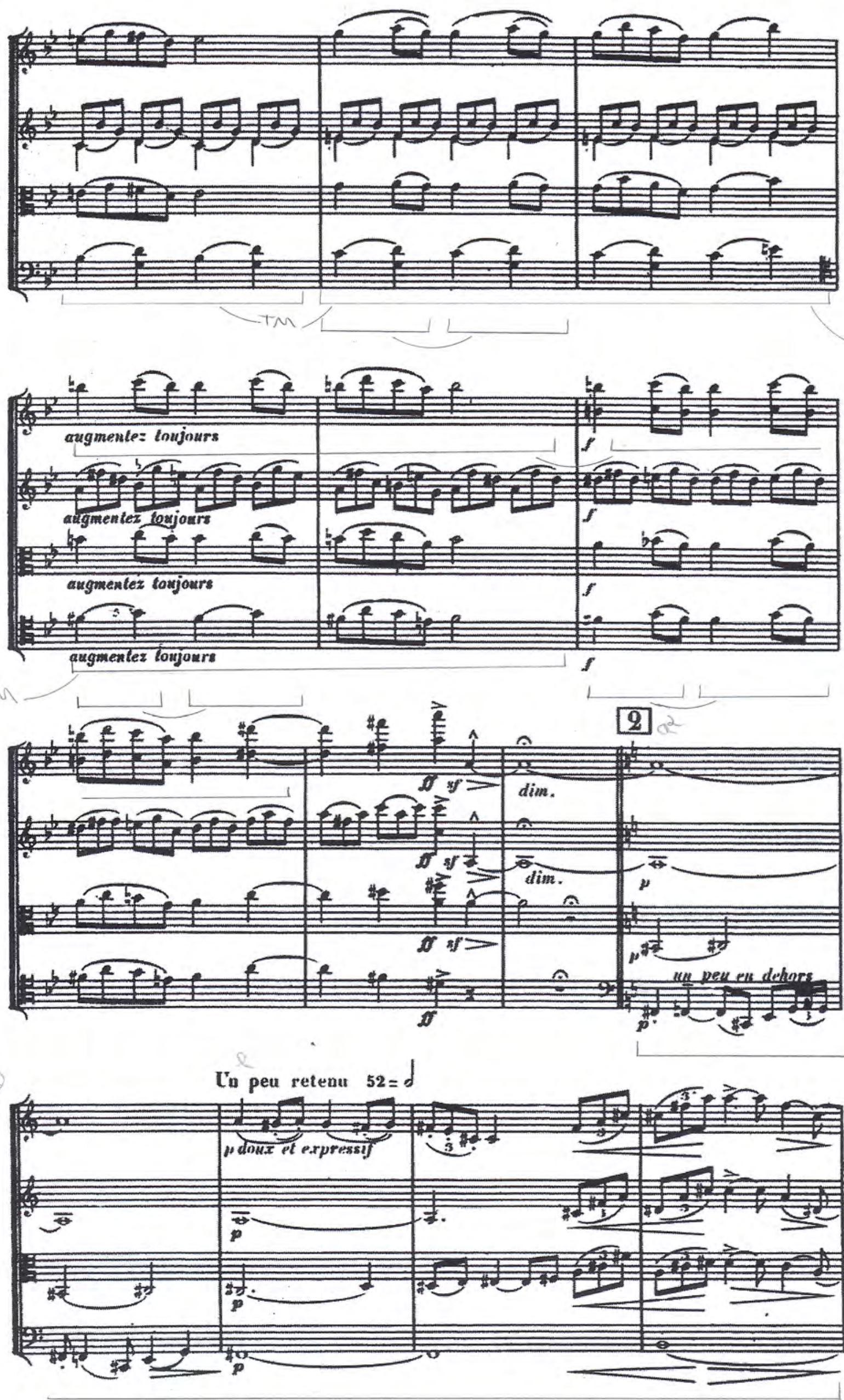


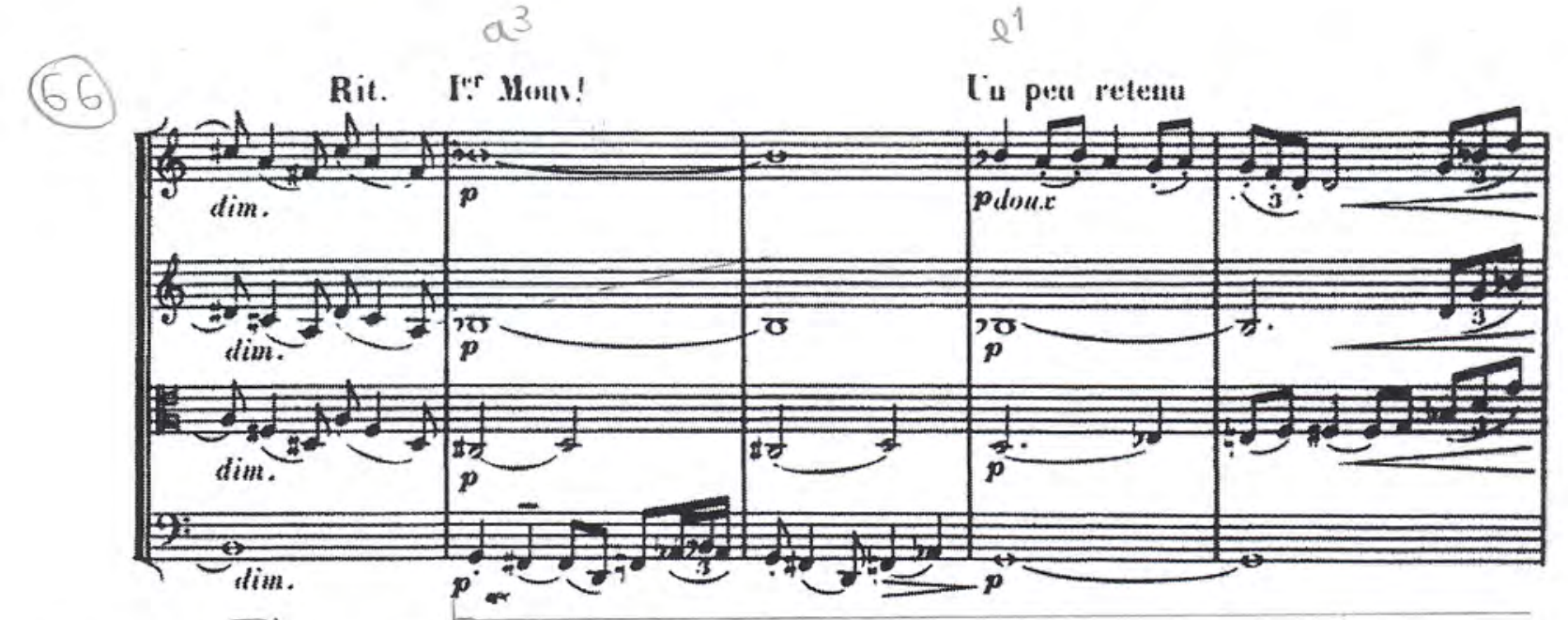

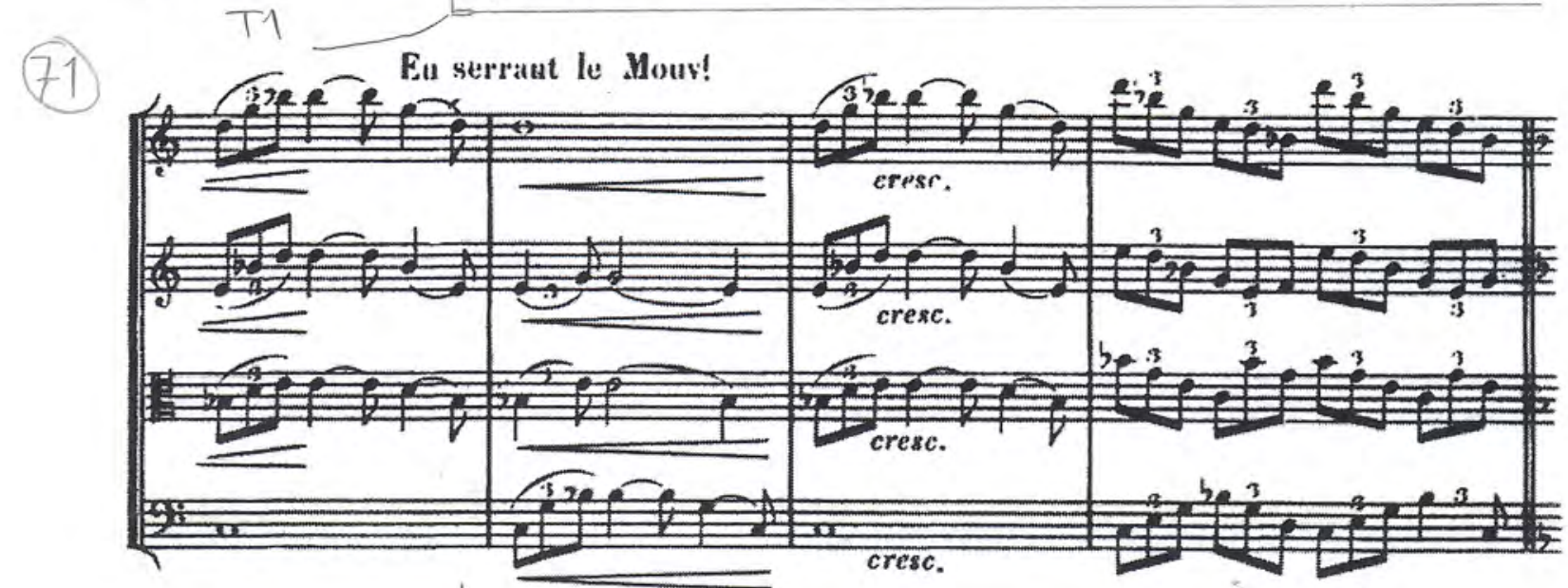
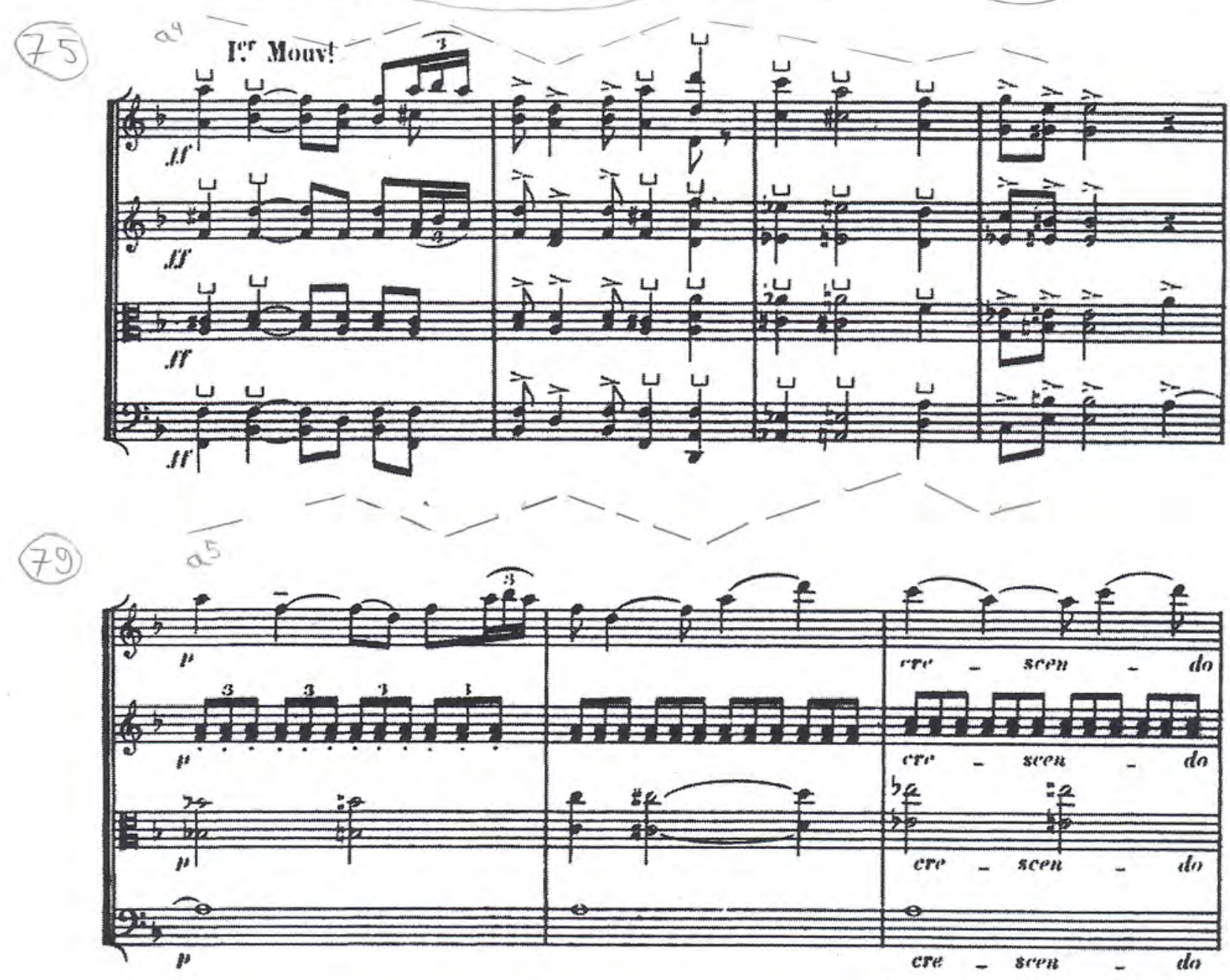
(82)
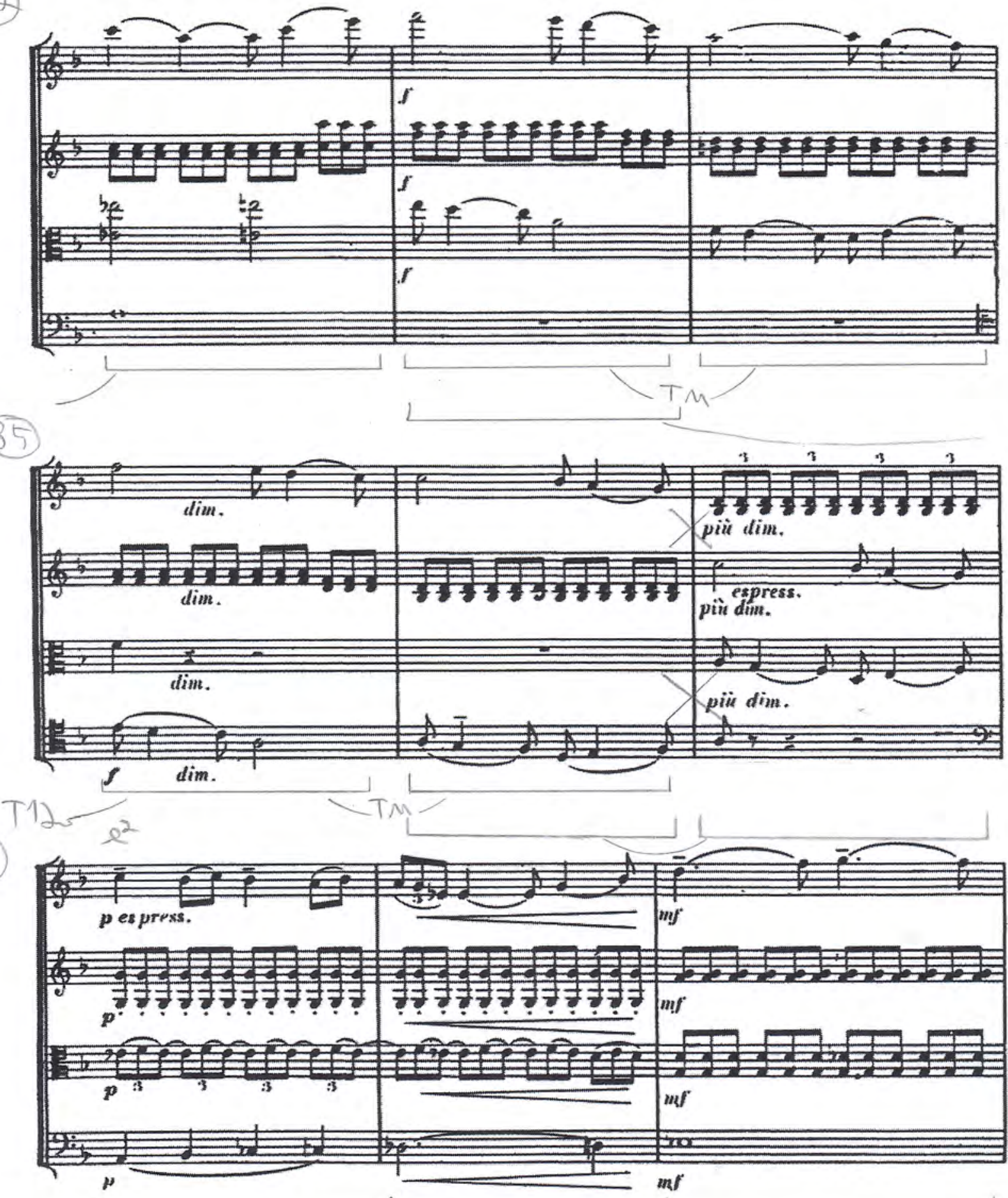

91

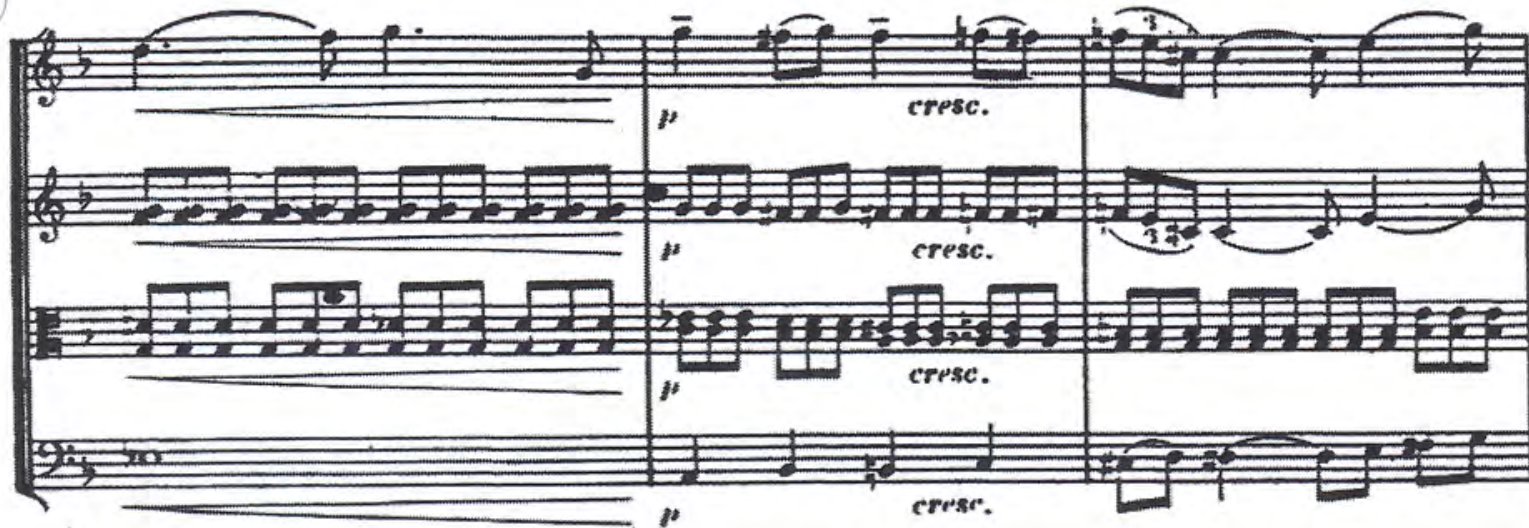




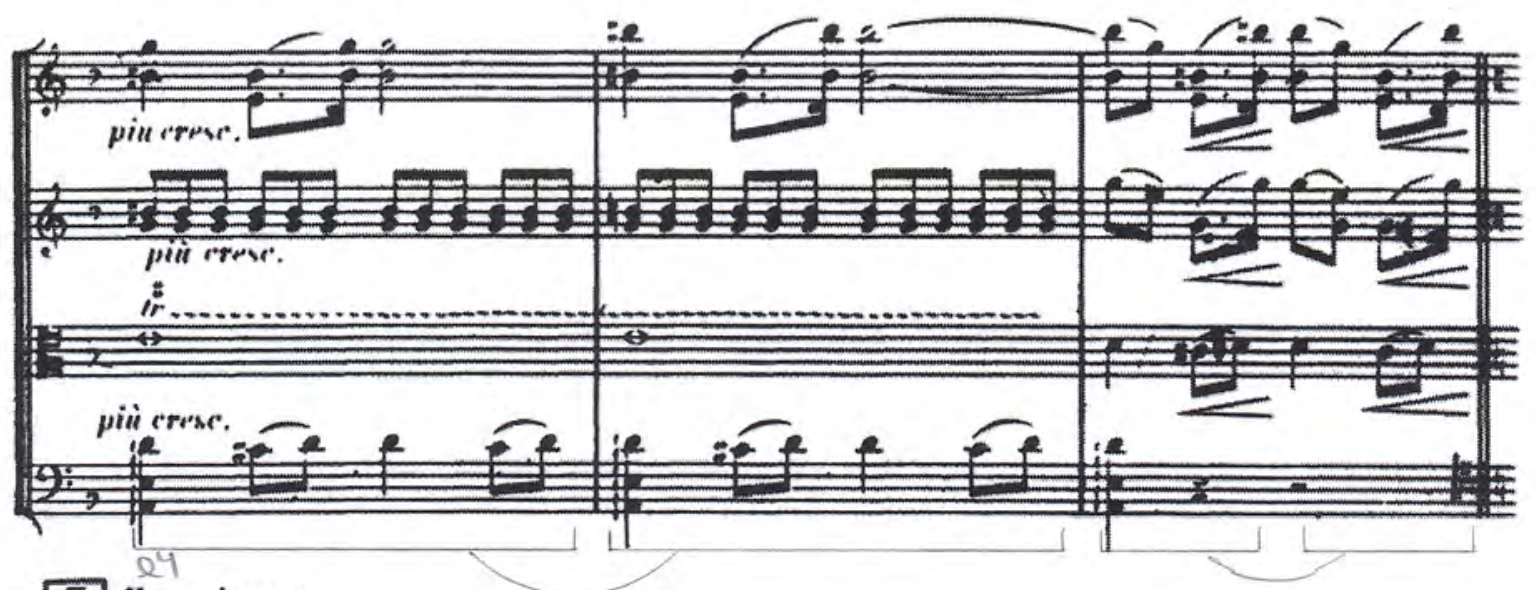

3. En animant

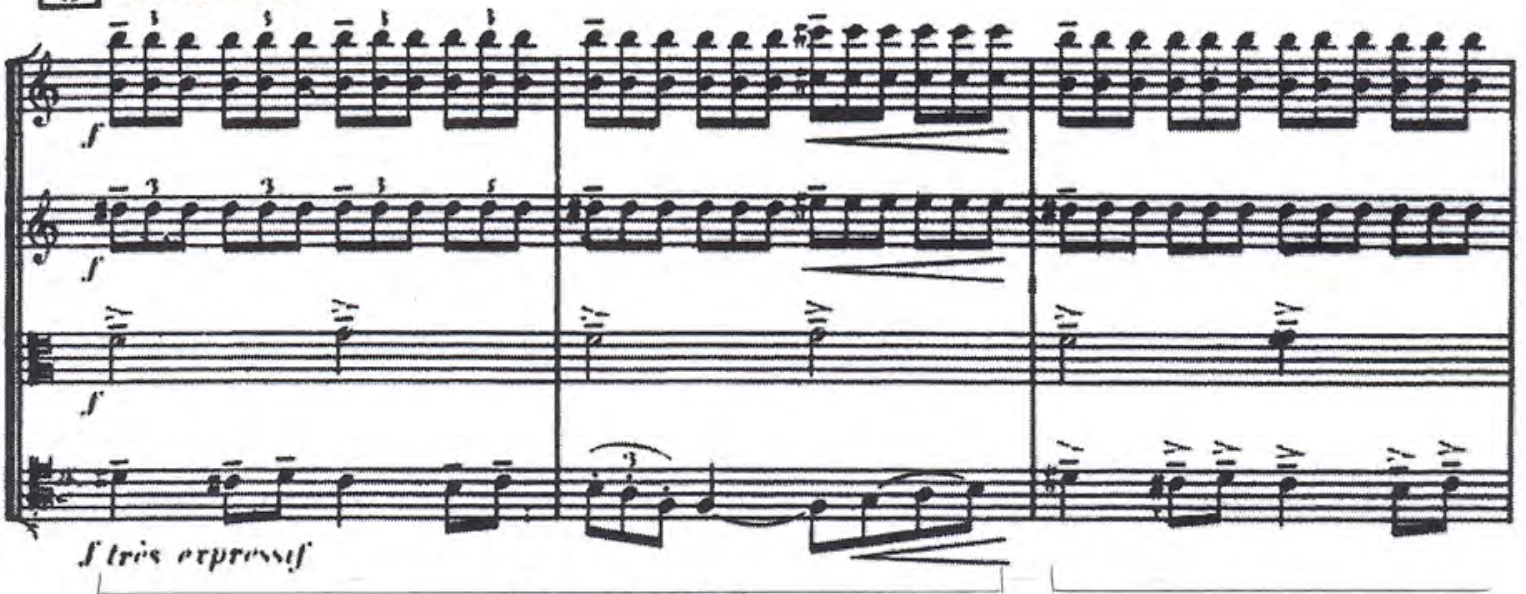

Toujours auimé

100

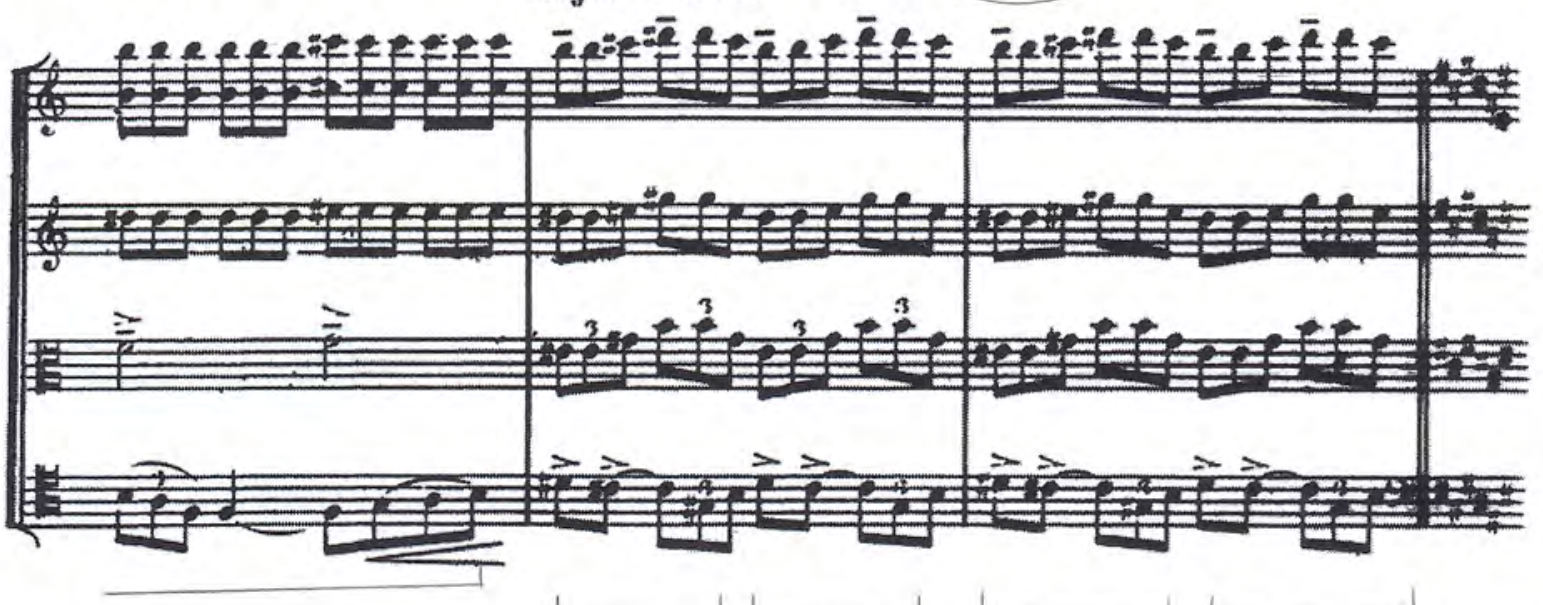

$2^{5}$

(103) 


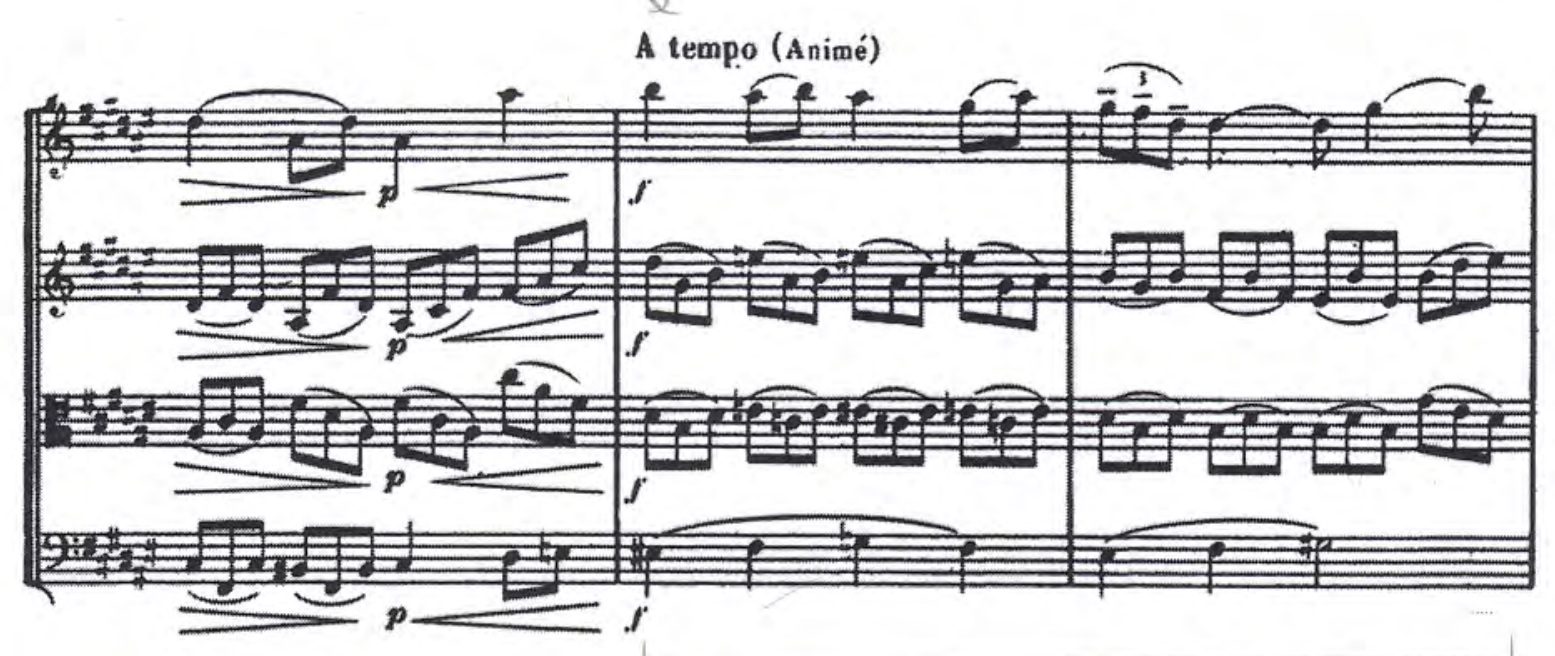

109

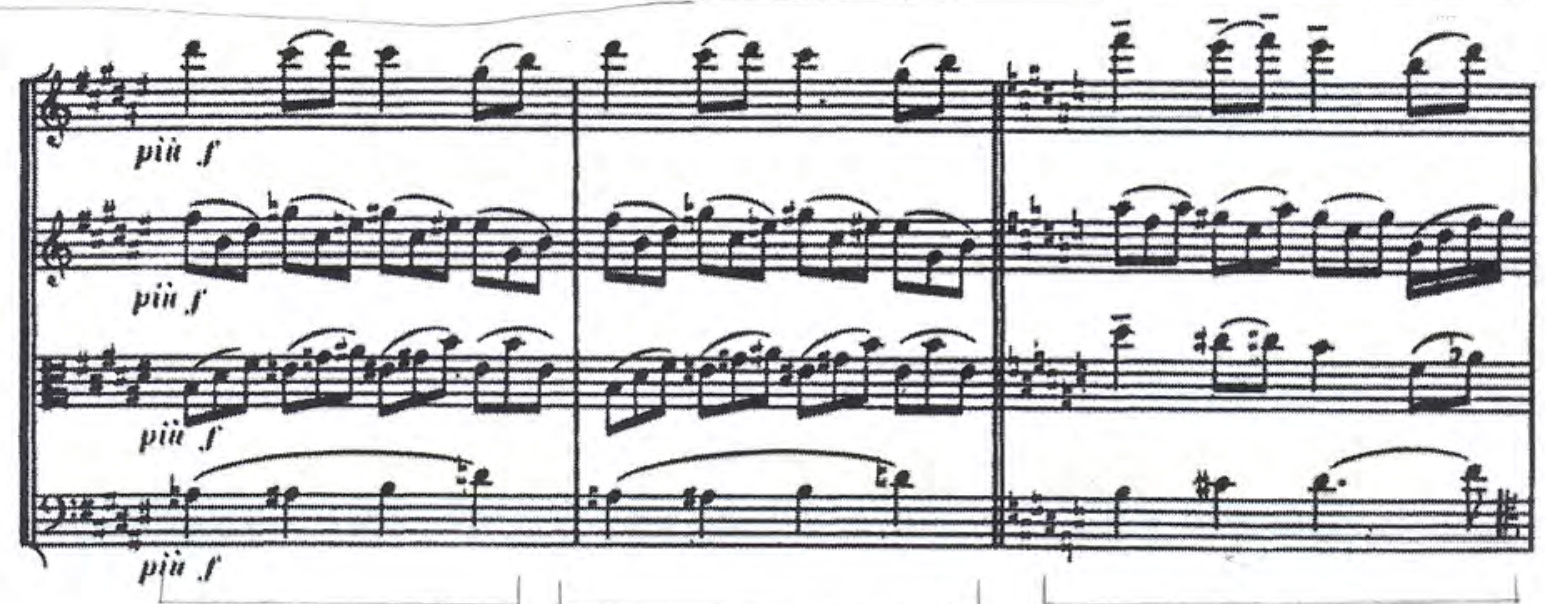

(112)

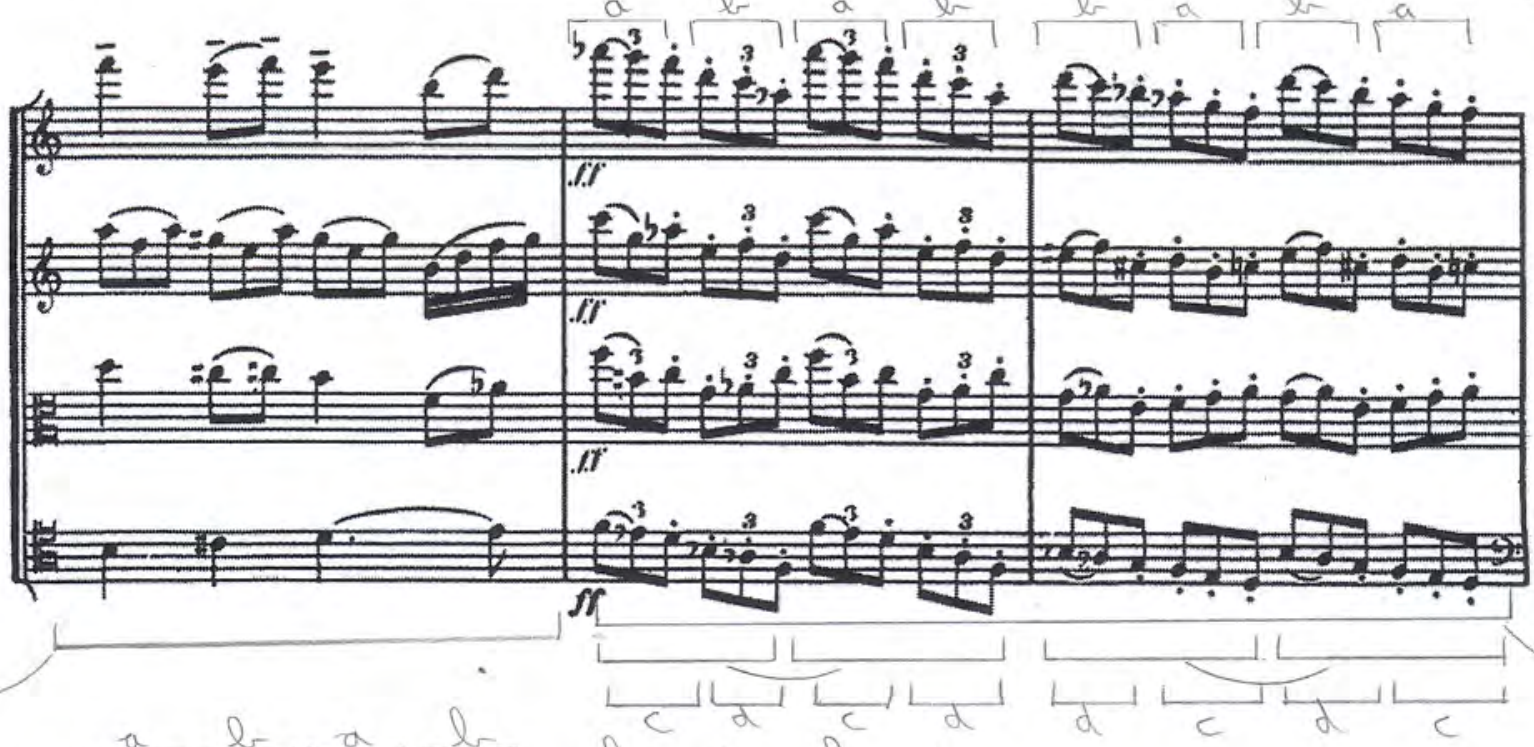

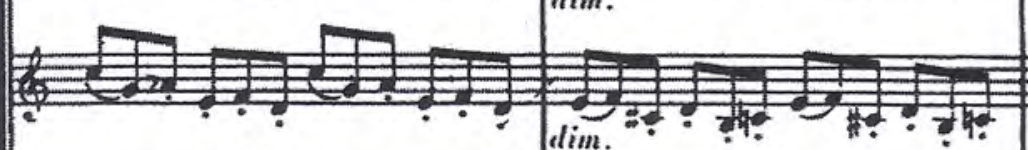
to lim. dim. ए: tris dim. 
(118)

4

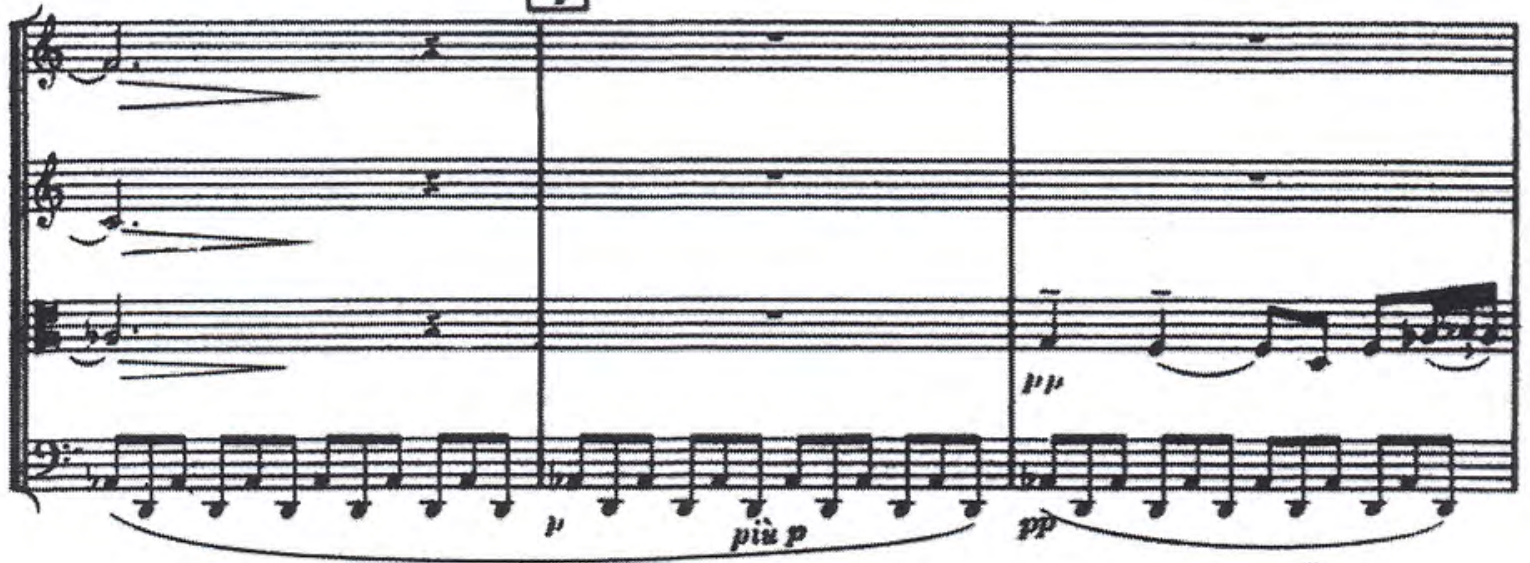

121

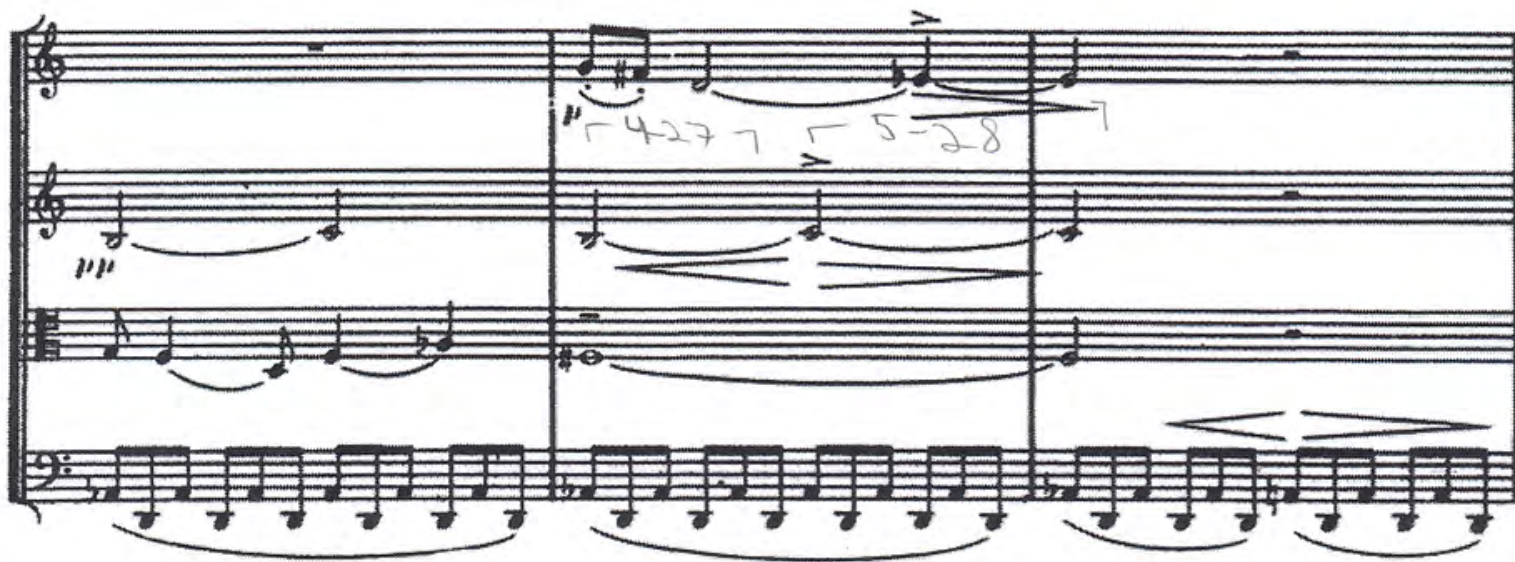

124

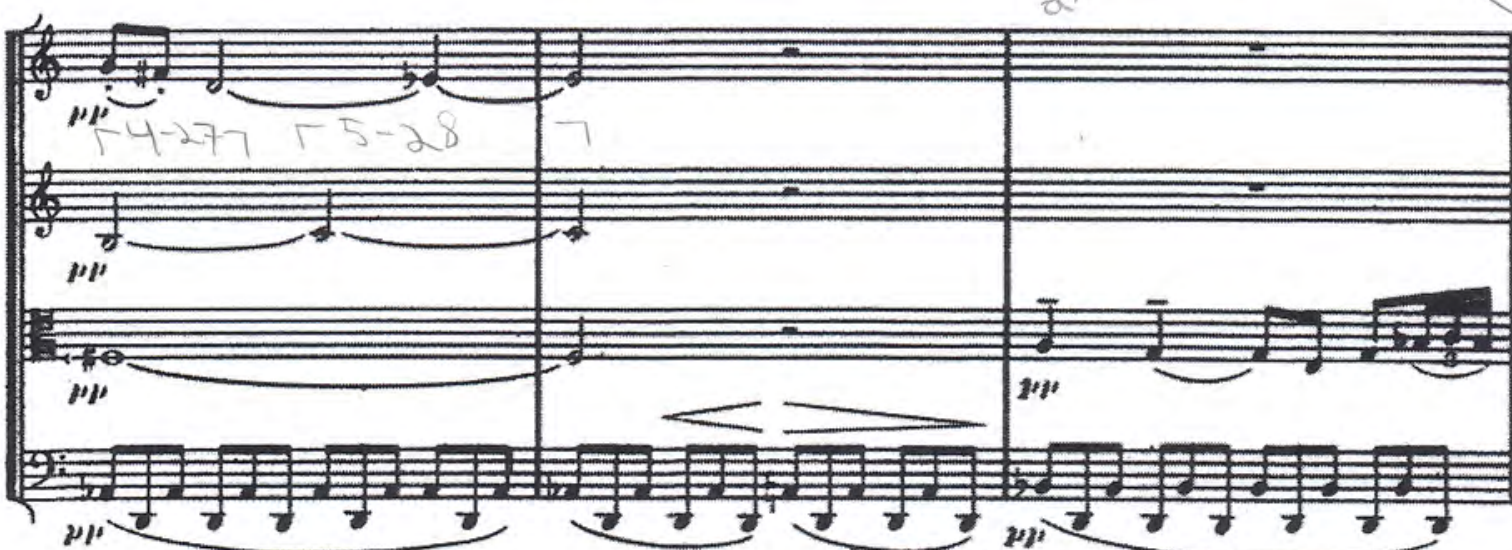

127

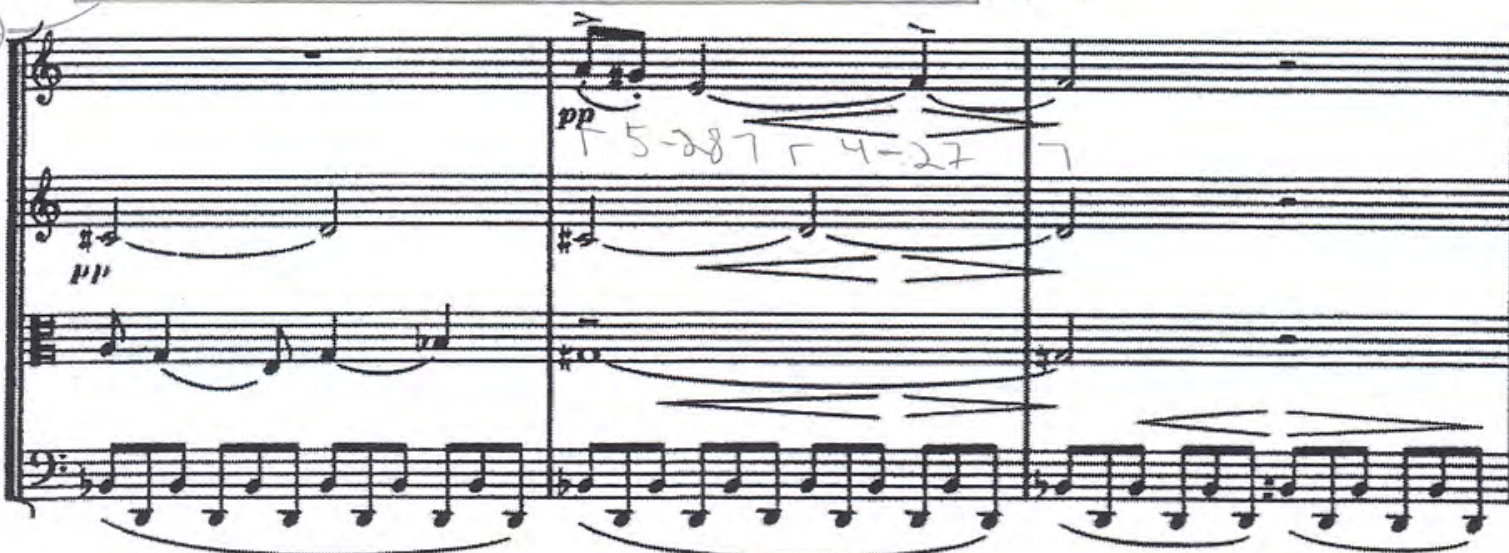



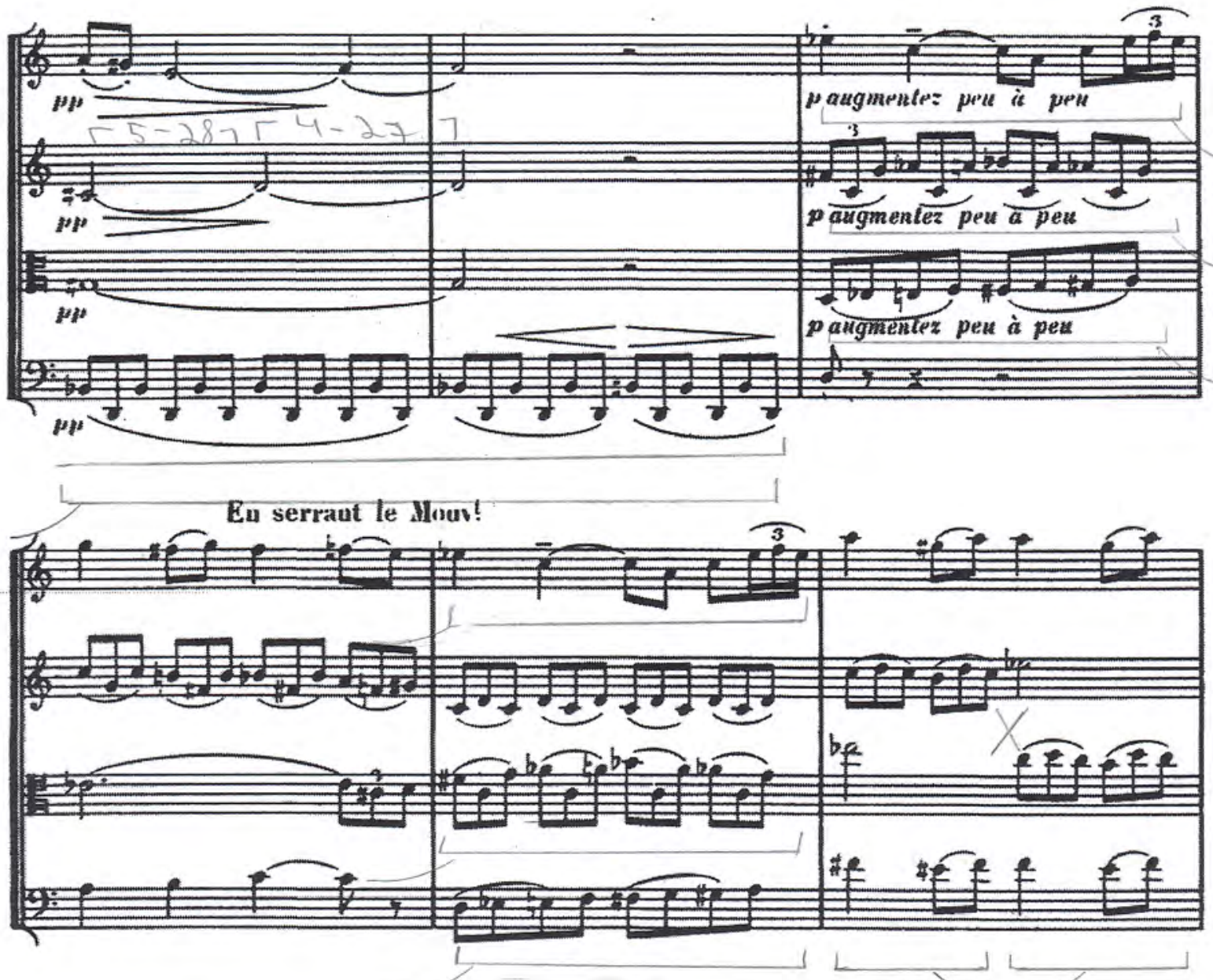

(136)

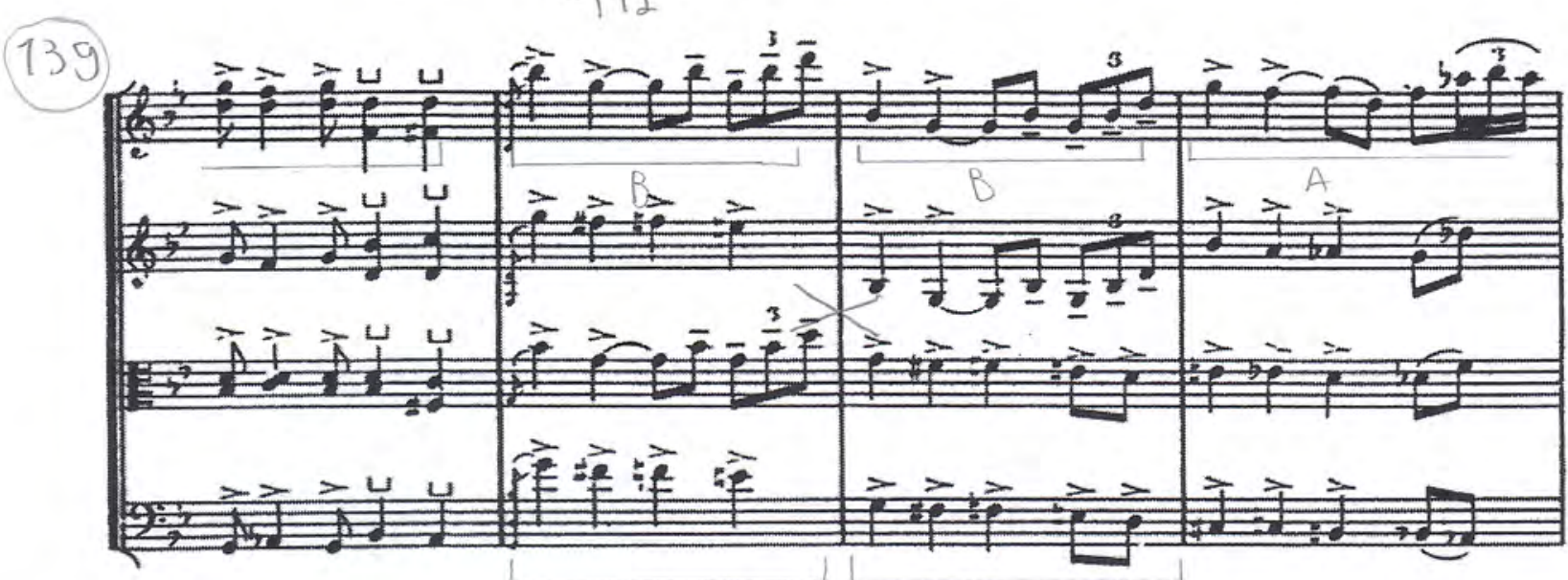




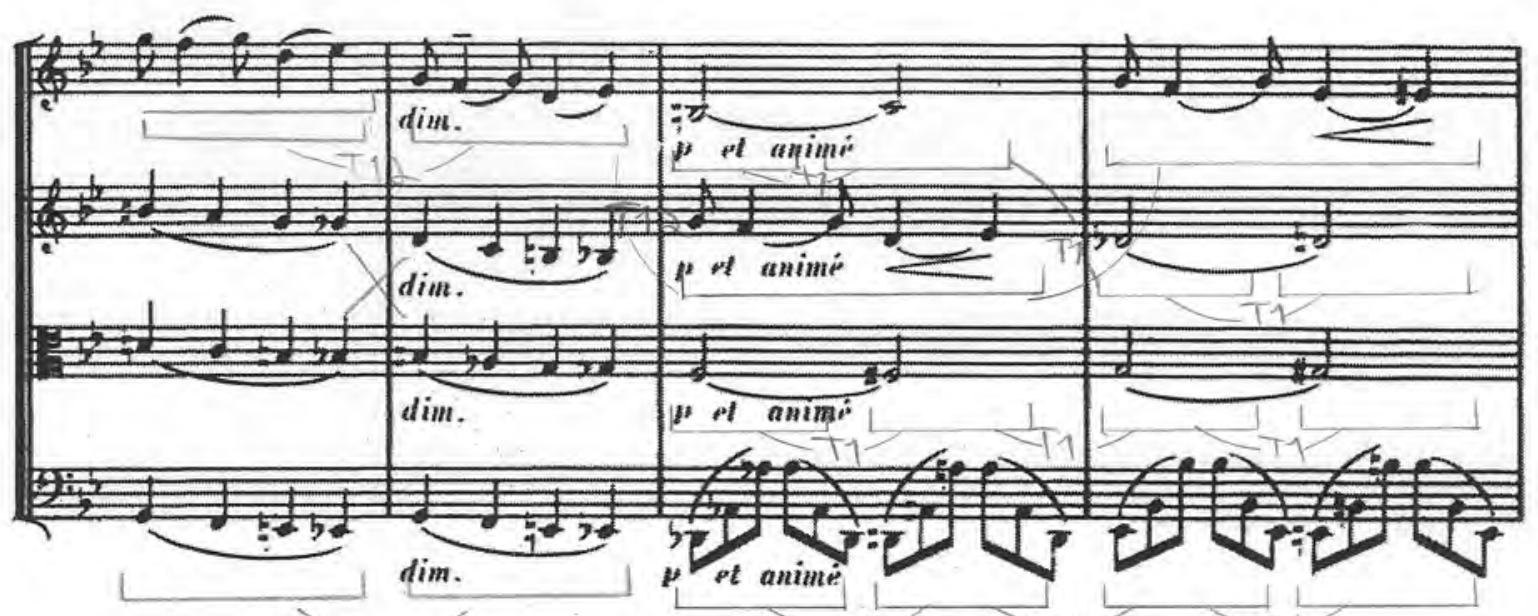

(147)
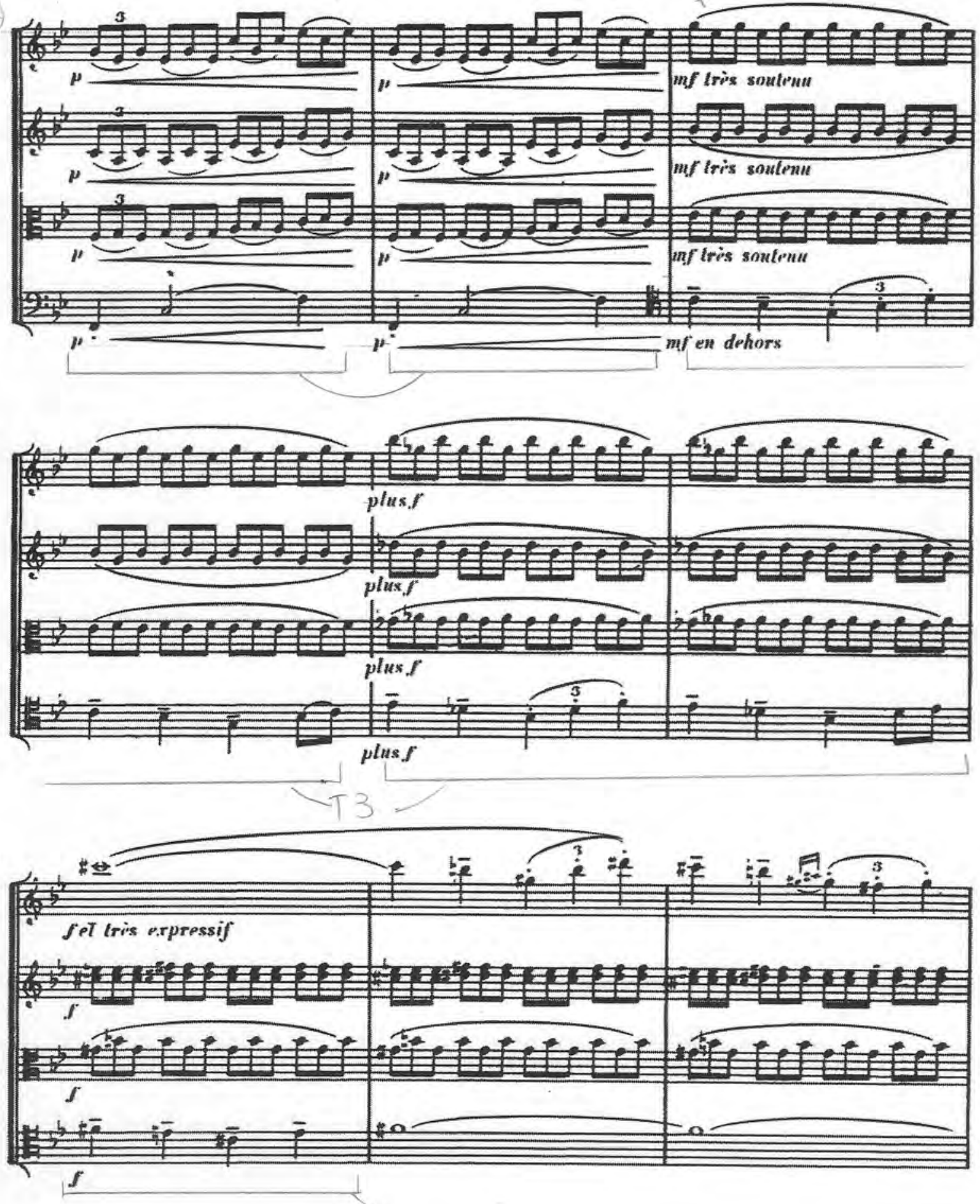

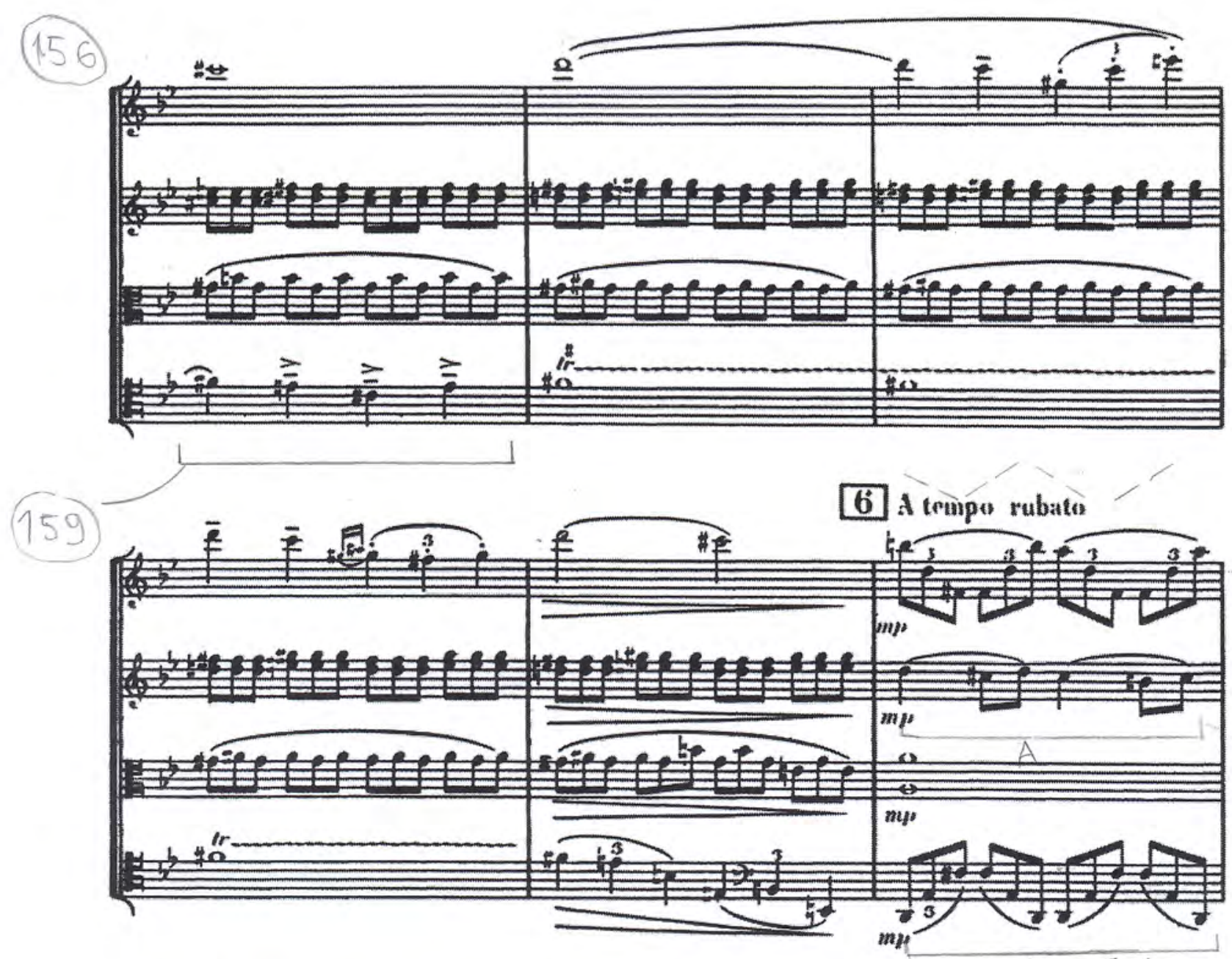

162.12

(165) 
168

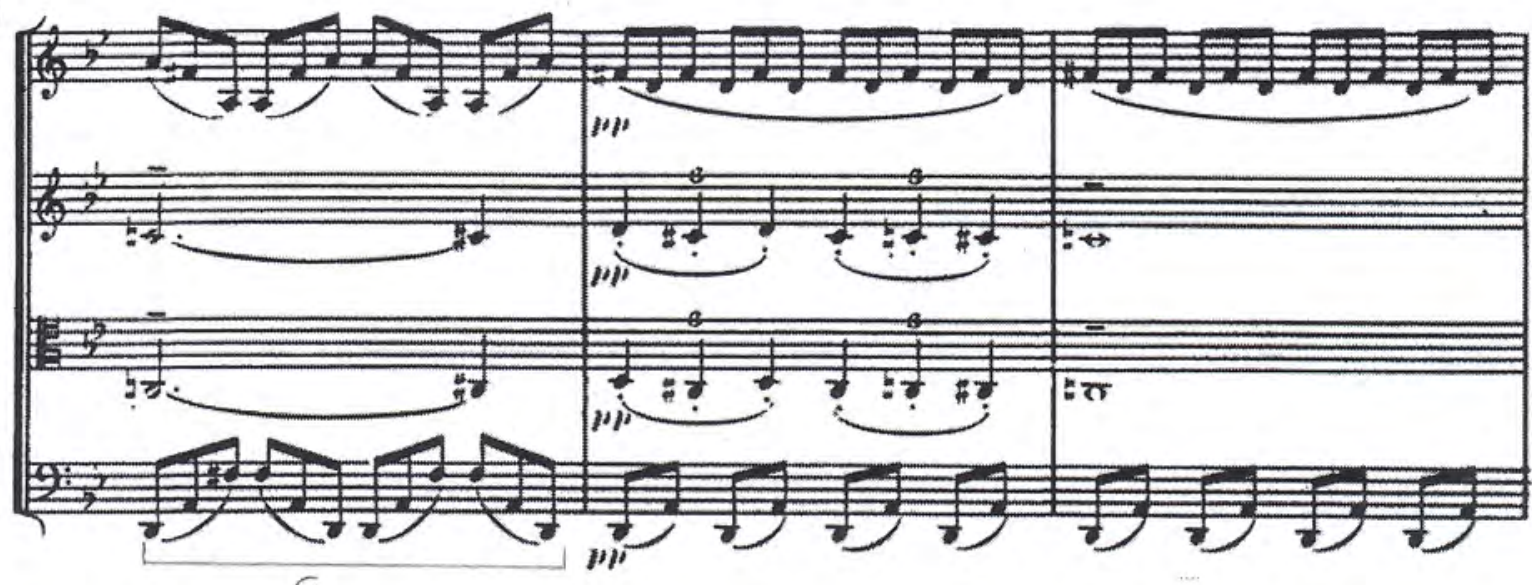

C
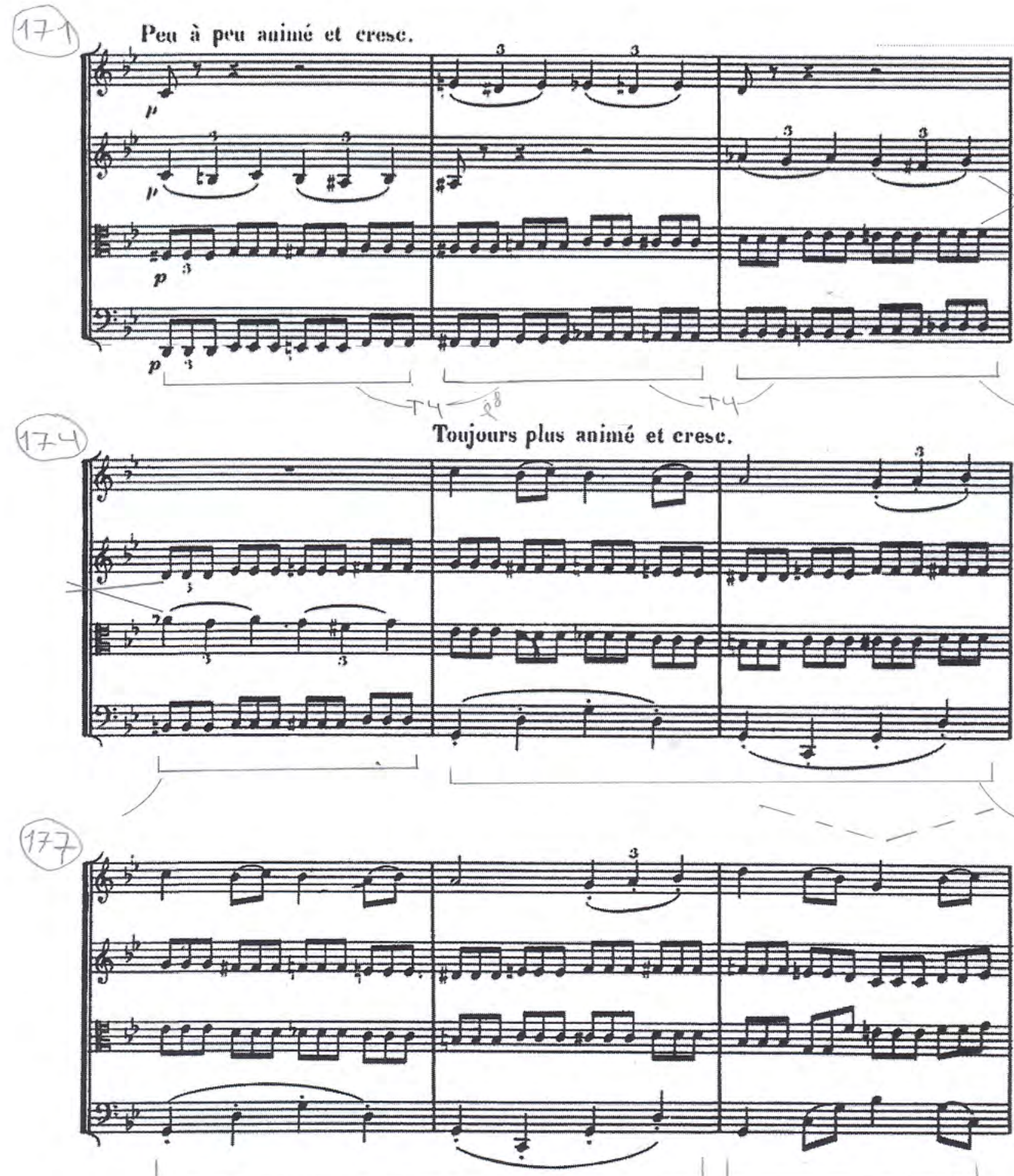
(180)

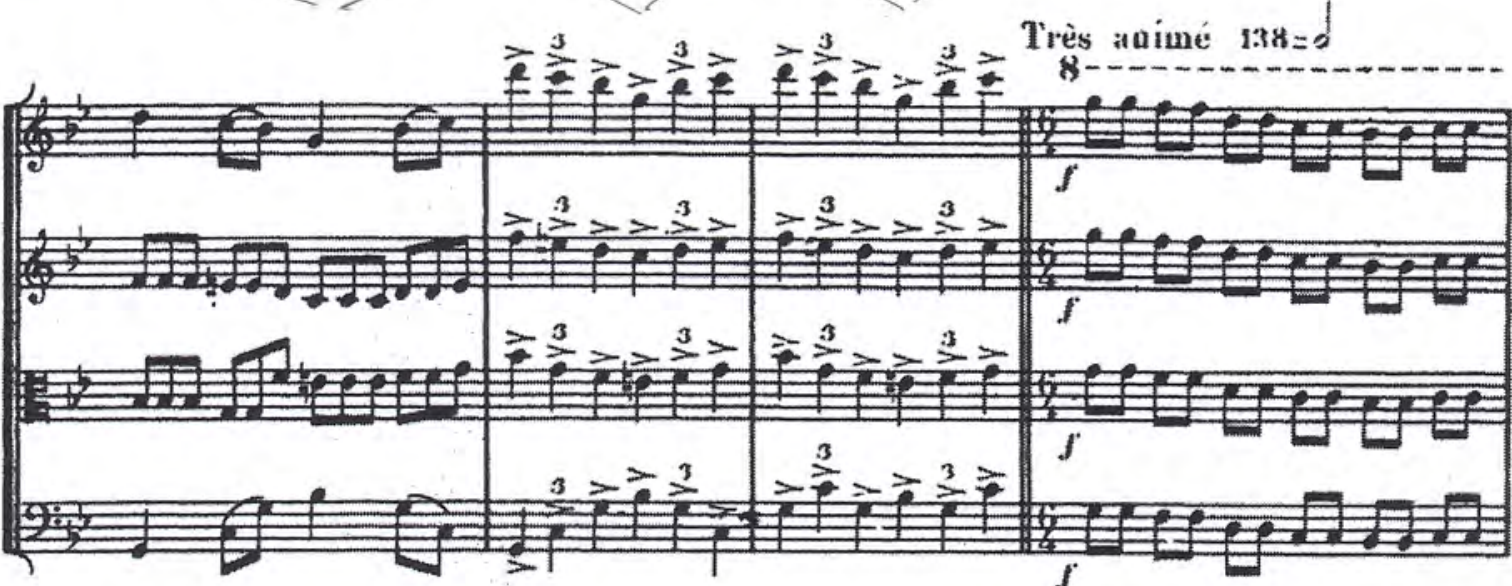

Très a aimé $138=0$

80

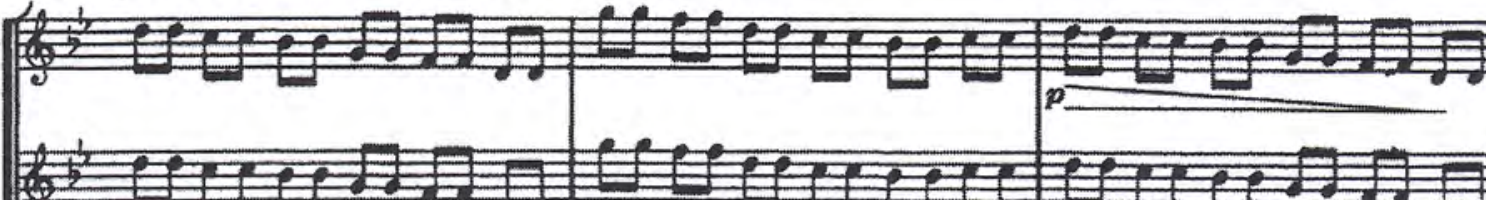
3.

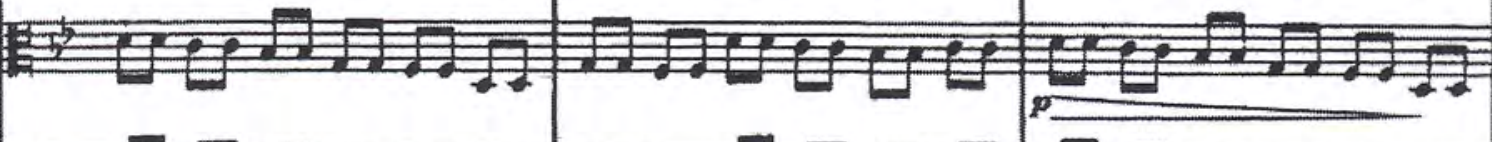

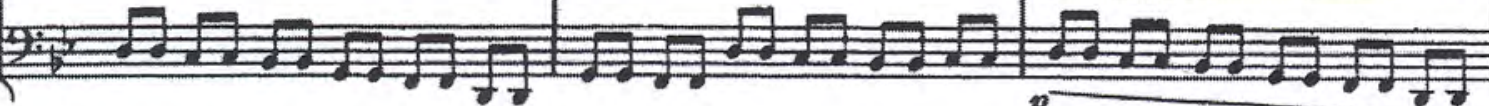

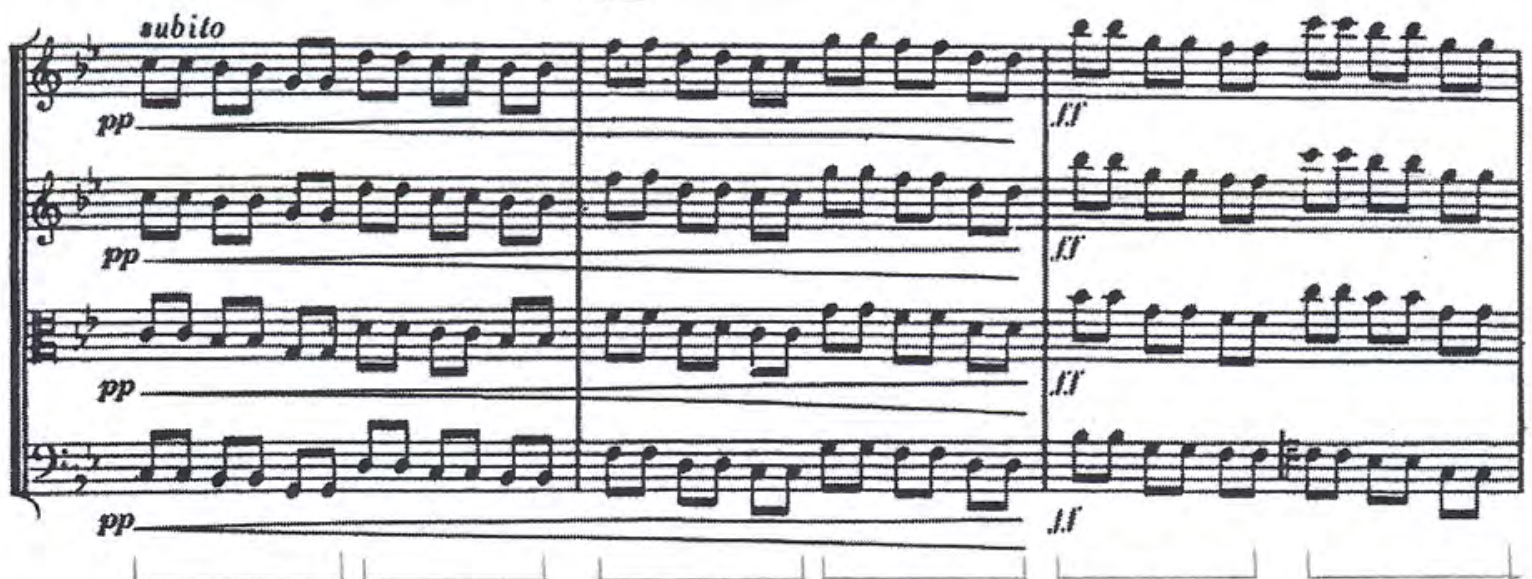

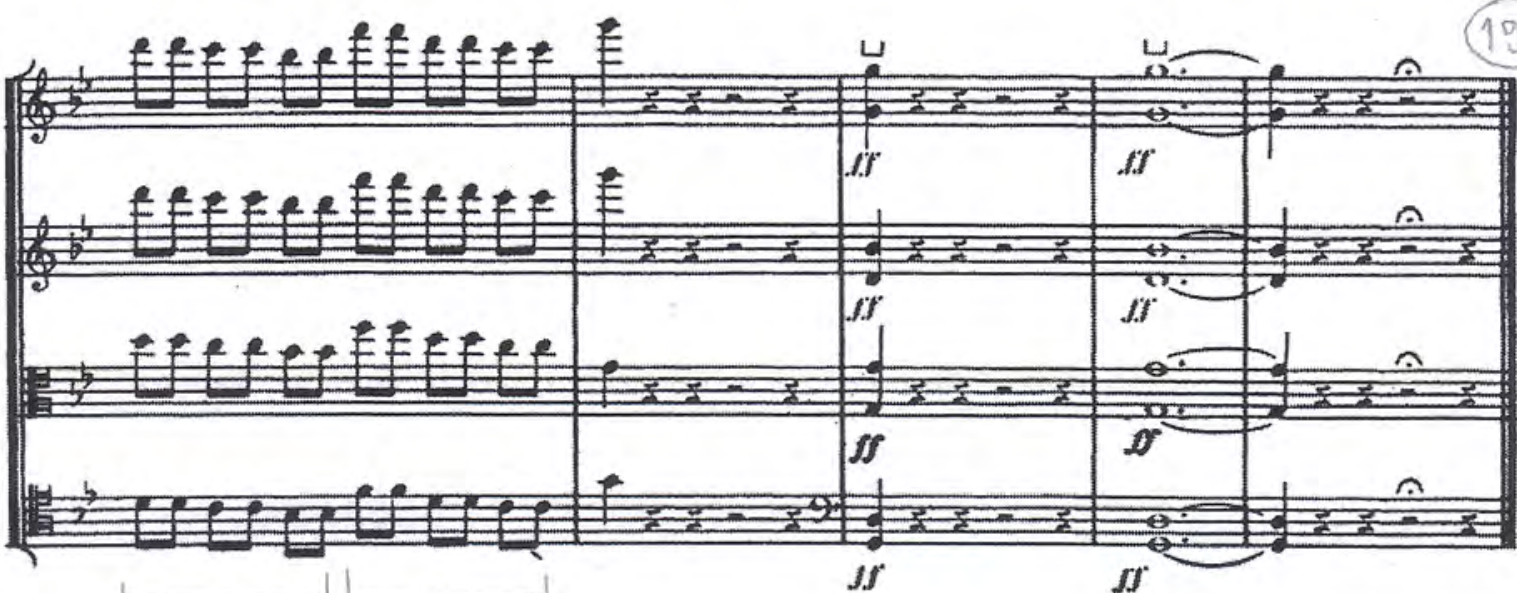

